(C) 2011 The Authors. Basin Research (c) 2011 Blackwell

Publishing Ltd, European Association of Geoscientists \&

Engineers and International Association of Sedimentologists

The definitive version is available at http://onlinelibrary.wiley.com/

\title{
A two-step process for the reflooding of the Mediterranean after the Messinian Salinity Crisis
}

\author{
François Bache ${ }^{1,2,3,{ }^{*}}$, Speranta-Maria Popescu ${ }^{4}$, Marina Rabineau ${ }^{5}$, Christian Gorini ${ }^{1,2}$, \\ Jean-Pierre Suc ${ }^{1,2}$, Georges Clauzon ${ }^{6}$, Jean-Louis Olivet ${ }^{7}$, Jean-Loup Rubino ${ }^{8}$,
} Mihaela Carmen Melinte-Dobrinescu ${ }^{9}$, Ferran Estrada ${ }^{10}$, Laurent Londeix ${ }^{11}$, Rolando Armijo ${ }^{4}$ Bertrand Meyer ${ }^{1,2}$, Laurent Jolivet ${ }^{12}$, Gwénaël Jouannic ${ }^{13}$, Estelle Leroux $x^{5,7}$, Daniel Aslanian ${ }^{7}$ Antonio Tadeu Dos Reis ${ }^{14}$, Ludovic Mocochain ${ }^{15}$, Nikola Dumurdžanov ${ }^{21}$, Ivan Zagorchev ${ }^{17}$, Vesna Lesić ${ }^{18}$, Dragana Tomić ${ }^{18}$, M. Namık Çağatay ${ }^{19}$, Jean-Pierre Brun ${ }^{20}$, Dimitrios Sokoutis ${ }^{21}$, Istvan Csato ${ }^{22}$, Gülsen Ucarkus ${ }^{19}$, Ziyadin Çakır $^{19}$

${ }^{1}$ UPMC Univ, Paris, France

${ }^{2}$ CNRS, Paris, France

${ }^{3}$ GNS Science, New Zealand

${ }^{4}$ Laboratoire de Tectonique, Institut de Physique du Globe de Paris (UMR 7154 CNRS), Paris Cedex, France

5 IUEM, Domaines océaniques (UMR 6538), Plouzané, France

${ }^{6}$ C.E.R.E.G.E. (UMR 6635), Université Paul Cézanne, Europôle de l'Arbois, Aix-en-Provence Cedex 04, France

7 IFREMER, Géosciences marines, LGG, Plouzané Cedex, France

8 TOTAL, TG/ISS, CSTJF, Pau Cedex, France

${ }^{9}$ National Institute of Marine Geology and Geoecology, Bucharest, Romania

${ }^{10}$ Instituto de Ciencias del Mar de Barcelona, C.S.I.C., Paseo Juan de Borbon s/n, Barcelona, Spain

${ }^{11}$ Université Bordeaux 1, UMR 5805 CNRS 'EPOC', Talence cedex, France

12 ISTO (UMR 6113), Université d'Orléans, Orléans Cedex 2, France

${ }^{13}$ Université Paris-Sud, Laboratoire IDES, UMR 8148, Orsay, France

${ }_{15}^{14}$ Departamento de Oceanografia Geologica/UERJ-Brazil, Rua São Francisco Xavier, Brazil

${ }^{15}$ Laboratoire de Géologie (UMR 8538), Ecole Normale Supérieure, Paris, Cedex 05, France

${ }_{17}^{17}$ Geological Institute, Bulgarian Academy of Sciences, Sofia, Bulgaria

${ }_{18}$ Geolomagnetic Institute, Belgrad, Republic of Serbia

${ }^{19}$ Istanbul Technical University, School of Mines and Eurasia Institute of Earth Sciences, Maslak, Istanbul, Turkey

${ }_{20}$ Géosciences Rennes (UMR 6118), Université Rennes 1, Rennes Cedex, France

${ }^{21}$ ISES, Vrije Universiteit Amsterdam, HV Amsterdam, The Netherlands

22 Department of Geology, Collin College, Plano, TX, USA

*: Corresponding author : François Bache, email address : f.bache@gns.cri.nz

\section{Abstract :}

The Messinian Salinity Crisis is well known to have resulted from a significant drop of the Mediterranean sea level. Considering both onshore and offshore observations, the subsequent reflooding is generally thought to have been very sudden. We present here offshore seismic evidence from the Gulf of Lions and re-visited onshore data from Italy and Turkey that lead to a new concept of a two-step reflooding of the Mediterranean Basin after the Messinian Salinity Crisis. The refilling was first moderate and relatively slow accompanied by transgressive ravinement, and later on very rapid, preserving the subaerial Messinian Erosional Surface. The amplitude of these two successive rises of sea level has been estimated at $\leq 500 \mathrm{~m}$ for the first rise and $600-900 \mathrm{~m}$ for the second rise. Evaporites from the central Mediterranean basins appear to have been deposited principally at the beginning of the first step of reflooding. After the second step, which preceeded the Zanclean Global Stratotype Section and Point, successive connections with the Paratethyan Dacic Basin, then the Adriatic foredeep, and finally the Euxinian Basin occurred, as a consequence of the continued global rise in sea level. A complex morphology with sills and sub-basins led to diachronous events such as the so-called 'Lago Mare'.This study helps to distinguish events that were synchronous over the entire Mediterranean realm, such as the two-step reflooding, from those that were more local and diachronous. In addition, the shoreline that marks the transition between these two steps of reflooding in the Provence Basin provides a remarkable palaeogeographical marker for subsidence studies. 
The almost complete desiccation of the Mediterranean Sea in the Messinian resulted in the deposition of thick evaporites in the central basins (Hsü et al., 1973; Rouchy \& Caruso, 2006) and the cutting of deep fluvial canyons (Chumakov, 1973; Clauzon, 1973, 1978, 1980a, 1982, 1990; Savoye \& Piper, 1991) (Fig. 1). The termination of the Messinian Salinity Crisis (MSC), i.e. the reflooding of the Mediterranean Basin, is classically considered to have been very sudden (Hsü et al., 1973; Clauzon \& Cravatte, 1985; Pierre et al., 1998; Blanc, 2002; Lofi et al., 2003). The generally accepted age for this event is that of the Zanclean Global Stratotype Section and Point (GSSP) at 5.332 Ma (Table 1; Hilgen and Langereis, 1993; Van Couvering et al., 2000; Lourens et al., 2004). Offshore, this very rapid event is reflected by the sharp contact between the Messinian evaporites and Zanclean mudrocks (Cita et al., 1978) or the Zanclean prograding sediments downlapping directly on the Messinian Erosional Surface (MES) (Lofi et al., 2003). Onshore, this contact is often reflected by the prograding sedimentary filling of Gilbert-type fan deltas within the Zanclean rias without any onlapping transgressive parasequence (Fig. 2; Clauzon, 1990). Indeed, in the earliest Pliocene, the Mediterranean Basin was starved of terrigenous sediments (Cita et al., 1978, 1999a) which concentrated within the rias. In several rias from southern France and northeastern Spain, the clayey bottomset beds of the Gilbert-type fan deltas have been dated by foraminifers from the Sphaeroidinellopsis Acme Zone (Zheng \& Cravatte, 1986; Clauzon \& Cravatte, 1985; Llobregat ria; Civis, 1977) in agreement with the nannofossil record (Matias i Sendra, 1990). The Gilbert-type fan deltas have been identified as infilling Messinian fluvial canyons all around the Mediterranean Basin and in adjacent territories as illustrated in Figure 1.

The question of the suddenness of the Mediterranean reflooding has been reopened since a progressive reflooding of the Mediterranean was advocated by Krijgsman et al. (1999a), possibly preceding the earliest Zanclean (Cavazza \& DeCelles, 1998; Cornée et al., 2006). The problem also arises when considering the significance of the Sicilian Upper Evaporites (7 gypsum-clay alternations) and their overlying deposits (Lago Mare and Arenazzolo units) preceding the Zanclean Trubi Formation. The matter is closely linked to the status of the Sicilian Caltanissetta Basin, a piggy-back basin located at that time some 150-200 km northward its present-day position (Boccaletti et al., 1990; Casero, 2004; Jolivet et al., 2006). The interpretation of the environmental setting of the basin is controversial, representing either (1) a deep Mediterranean central basin later uplifted (Hsü et al., 1973; Krijgsman et al., 1999a; Rouchy \& Caruso, 2006; Roveri \& Manzi, 2006; Krijgsman \& Meijer, 2008; Roveri et al., 2008a $\&$ b) assuming a synchronism of these evaporites with those of the Mediterranean central basins or (2) a marginal (even relatively deep) domain (Brolsma, 1975; Butler et al., 1995; Clauzon et al., 1996; Popescu et al., 2009) assuming older evaporites than those of the central basins. This question has been discussed for a long time (Hsü et al., 1973) and is still intensely debated (e.g. Rouchy \& Caruso, 2006; CIESM, 2008). Recent data acquired offshore Tunisia (Sicily Strait) support the hypothesis that the Caltanissetta Basin was rather a marginal basin even if it deepens significantly from North to South (El Euch - El Koundi et al., 2009).

A very fast process for the Mediterranean reflooding after the MSC was until now considered satisfactory since finer resolution data based on biostratigraphy or seismic data were not available. This paper reviews recent offshore seismic evidences from the Gulf of Lions and their relationship with boreholes (Bache et al., 2009) showing two types of erosional surfaces in regressive and transgressive conditions, respectively. We re-visited and synthetised recently published onshore data documenting the post-MSC marine transgression in different paleoenvironmental contexts, particularly from Italy (Sicily: Londeix et al., 2007; Popescu et al., 2009; Marche: Popescu et al., 2007) and Turkey (Melinte et al., 2009) (Fig. 3). Several published and new age determinations will be repeatedly used in this paper. In order to help the reader, they have been summarized in Table 1, pointing out which event they date and how and where they have been obtained within the relative literature. Nannofossils have been intensively 
used for defining the chronostratigraphic position of the exposed sections considered here (see: Popescu et al., 2007; Melinte et al., 2009) following the chart shown in Figure 4 (Berggren et al., 1995; Raffi et al., 2006) where are indicated the two-steps of the MSC proposed by Clauzon et al. (1996) which are now widely accepted (CIESM, 2008; Ryan, 2011). After displaying data from the Gulf of Lions that illustrate a post-MSC reflooding of the Mediterranean in two steps, we discuss its reliability in the eastern basin and its potential chronology. We then consider the geodynamic causes and attenpt to quantify the sea level changes, leading to a revision of the late Messinian - early Zanlcean eustatic events in the Mediterranean region (see the map of Figure 3 for most of the localities cited in the paper).

\section{Offshore data}

Due to its location near the Strait of Gibraltar, the Western Mediterranean is critically located for recording any connection with the Atlantic Ocean. Within the Western Mediterranean, the Gulf of Lions is exceptional in that its Neogene sedimentary strata have not been significantly deformed except for salt-related tectonics in the deep basin (Gaullier, 1993; Dos Reis et al., 2008) and no significant post-sedimentation uplift has occurred in the deep basin. This area can thus be considered as a good reference for sea level variations in the whole Mediterranean Basin. In addition, the Gulf of Lions has been characterized by a relatively high total subsidence rate which has continuously created accomodation space (Steckler \& Watts, 1980; Bessis, 1986; Burrus, 1989; Rabineau et al., 2005; Bache et al., 2010). This configuration, together with the availability of numerous offshore data (seismic profiles, boreholes), have permitted accurate descriptions of the transition between the Messinian halite identified in the central Mediterranean basins and the Zanclean prograding sediments (Gorini, 1993; Lofi, 2002; Lofi et al., 2005; Bache, 2008; Lofi \& Berné, 2008; Bache et al., 2009). Here, we will review these observations.

\subsection{Seismic profiles}

Three key-surfaces intercalated between the pre-crisis Miocene deposits and the Pliocene ones can be identified in the Gulf of Lions (Figure 5).

The first key-surface ("f" on Figure 5) is the "Messinian Erosional Surface" (MES) also named "Margin Erosional Surface" by Lofi \& Berné (2008). This surface corresponds to the discordant contact between the Miocene deposits ("a" on Figure 5) and the overlying prograding Pliocene and Pleistocene sequence (" $g$ " on Figure 5). This pervasive erosional surface has long been identified in the Rhône Valley (Denizot, 1952; Clauzon, 1973 \& 1982) and on the Gulf of Lions shelf (Ryan \& Cita, 1978; Gennesseaux \& Lefèbvre, 1980; Lefèbvre, 1980; Gorini, 1993; Guennoc et al., 2000; Dos Reis, 2001; Lofi, 2002; Dos Reis et al, 2005; Lofi et al., 2005; Dos Reis et al, 2008). The mapping of this surface shown in Figure 6 revealed a pattern of up to $5^{\text {th }}$ order dendritic drainage and represents a subaerial landscape (Gennesseaux \& Lefèbvre, 1980; Gorini et al., 1993; Guennoc et al., 2000; Lofi et al., 2005). Beneath the shelf, the sudden reflooding at the end of the MSC is supported by the Zanclean prograding sediments downlapping directly on the MES (Lofi et al., 2003). The MES therefore represents the preserved subaerial landscape just before reflooding generally dated at $5.332 \mathrm{Ma}$ (Table 1 ; see also the "Introduction" section). The landscape corresponding to the onset of the drawdown has not been preserved on the shelf because of uninterrupted subaerial exposure during the Messinian drawdown.

The second key-surface is the "Basal Erosional Surface" (BES) ("b" on Figure 5) which corresponds to the discordant contact between the pre-crisis Miocene deposits and the syncrisis detrital ones (Maillard et al., 2006). At the present time, a controversy exists concerning its 
significance. Bache (2008) and Bache et al. (2009), based on a detailed mapping of this surface, considered the "Basal Erosional Surface" as the actual marker of the Messinian drawdown in the basin ("b" on Figure 5). On the contrary, Lofi \& Berné (2008) interpreted this surface as a pre-MSC discordance related to sub-marine slope canyon erosional systems and placed the "Basal Erosional Surface" higher in the Miocene series. A full discussion about the consequences of these interpretations is beyond the scope of this paper but can be found in Bache et al. (2009).

Finally, the third surface (planation surface "e" on Figure 5) is a straight and smooth surface that is locally conformable with the underlying pre-crisis series (between 64 and $90 \mathrm{~km}$ from the coast on Figure 5) but that is also locally erosional $(90-100 \mathrm{~km}$; Figure 5) as it truncates the underlying syn-crisis series (Bache, 2008; Bache et al., 2009). Above this surface, sedimentary units are characterized by onlap termination of seismic reflectors in the deepest part and downlap termination in the shallower part (Figs. 5 and 7). The limit between the MES and the planation surface "e" is clear and occurs at a constant two-way travel time of 1.6 seconds over most of the shelf (Figs. 5, $6 \&$ 7). Towards the basin, the limit of salt deposition represents the maximum extension of erosion. The planation surface "e" thus extends over $50 \mathrm{~km}$, from the shelf to the basin (Fig. 6).

\subsection{Boreholes}

Boreholes located on the shelf (Fig. 6) show that the MES truncates Miocene sediments and underlies the earliest Pliocene sediments (Cravatte et al, 1974; Gorini et al, 1993; Guennoc et al, 2000; Lofi et al, 2003). The youngest Miocene sediments were found in the Tramontane1 well and were dated as Tortonian (Cravatte et al., 1974), i.e. between 11.61 and $7.25 \mathrm{Ma}$ (Lourens et al., 2004). The record of the Upper Miocene sediments is missing, having been removed by subaerial erosion during the MSC. The amplitude of erosion during the MSC reaches at least $1 \mathrm{~km}$ in the central part of the Languedoc shelf (Lofi et al., 2005; Bache, 2008; Bache et al., 2009).

Boreholes Autan1 and GLP2 drilled on the slope (Fig. 6) cross surface "e" respectively in its landward and seaward areas (Fig. 5). In Autan1 borehole, a very sharp contact occurring at $2424 \mathrm{~m}$ depth is described between a littoral to mid-shelf Upper Miocene environment and an outer shelf - upper slope earliest Pliocene environment (Cravatte et al., 1974). In GLP2 borehole (Guennoc et al., 2000), salt and anhydrite deposits alternating with calcareous clays related to the MSC have been described in the well (between 3703 and $3437 \mathrm{~m}$ ) and underlie the planation surface "e" (Fig. 8). Fifty metres of azoic sandy clays intercalated with micaceous sandstone have been drilled between the salt deposits and the lowermost Pliocene clays.

\section{Onshore data}

Three main areas will be considered here (Sicily, Marche and Dardanelles; Fig. 3) which show common characteristics of the terminal MSC in various paleoenvironments. We will then discuss the presence of coarse blocks deposits between the MES and Gilbert-type fan delta sediments (i.e. the Block Formation of Fig. 2) which are now observed in the whole Mediterranean region.

\subsection{Eraclea Minoa (Sicily)}

The cyclic pattern of the Sicilian Upper Evaporites (six gypsum - clay cyclothems) has been described by many authors (Fig. 9A; Decima \& Wezel, 1971; Nesteroff \& Glaçon, 1977; Homewood et al., 1992; Bonaduce \& Sgarrella, 1999; Rouchy \& Caruso, 2006; Krijgsman \& 
Meijer, 2008; Manzi et al., 2009), especially in the Eraclea Minoa key-section (Fig. 3 \& 9C). The calibration of the Upper Evaporites with the Astronomical Tuned Neogene Time Scale (ATNTS2004: Lourens et al., 2004) from 5.52 to 5.332 Ma has been proposed considering a continuous sedimentation in the Sicilian Basin during the peak of the MSC (Krijgsman \& Meijer, 2008; Roveri et al., 2008a, b). Each sequence ranges from brackish (gypsum and lowermost clay) to marine (clay overlain by diatomite and turbidites, i.e. the highest relative sea level) (Homewood et al., 1992). This interpretation is supported by geochemistry (Pierre \& Fontès, 1979), foraminifers (Nesteroff \& Glaçon, 1977), dinoflagellate cysts (Londeix et al., 2007) and pollen grains (Suc \& Bessais, 1990; Fauquette et al., 2006).

Here, we focus on the uppermost cycle, constituted by the last gypsum bed overlain by clays (Lago Mare Unit) and silts (Arenazzolo Unit), immediately below the Trubi carbonates (Fig. 9). Following Cita \& Colombo (1979), we emphasize the distinction between the Lago Mare and Arenazzolo deposits, often improperly grouped within the Arenazzolo Unit (Decima \& Wezel, 1971; Bonaduce \& Sgarrella, 1999) or a "Lago Mare - Arenazzolo" Unit (Rouchy \& Caruso, 2006). From bottom to top, the Lago Mare, Arenazzolo and Trubi formations represent quite different environmental conditions: (i) brackish shallow-water conditions as shown by the faunal content (ostracods; dreissenids, i.e. freshwater bivalves coming from the Dacic and Euxinian basins: Fig. 1); (ii) a higher energy littoral environment and (iii) open marine conditions, as shown by foraminiferal fauna (Cita \& Colombo, 1979) and dinoflagellate cyst flora (Londeix et al., 1999, 2007). An intense debate arose from the discrepancies and large uncertainties about the paleo-water depth estimates for the Trubi deposition. Using quantitative studies on benthic foraminifers, Brolsma (1978) proposed 100 to $1000 \mathrm{~m}$, whereas Cita \& Colombo (1979) proposed 1400 to $2400 \mathrm{~m}$, using benthic foraminifers and the sharp sedimentary contrast between the uppermost Messinian deposits and lowermost Zanclean ones, both in exposed sections and DSDP wells. Disagreement also concerns the location of the most significant environmental change. Cita \& Gartner (1973) and Cita et al., (1999b) proposed the location of the environmental break at the base of the Trubi emphasizing the presence of a sharp and even unconformable contact. Brolsma (1975) interpreted the Arenazzolo Unit as a transitional interval leading to the Trubi conditions and proposed locating the environmental break between the Lago Mare and Arenazzolo units. The Zanclean GSSP was eventually established at the base of the Trubi (Van Couvering et al., 2000).

At Eraclea Minoa, two sections located on both sides of the Zanclean GSSP were studied (Londeix et al., 2007; Popescu et al., 2009) (Figs. 9C \& D).

Section 1 (Fig. 9E \& F) starts with clays and diatomitic turbidites underlying the highest gypsum bed of the Sicilian Upper Evaporites. This bed is overlain by the Lago Mare Unit (7.80 m thick), constituted by clay deposits, which includes in its upper part three characteristic layers (two dreissenid coquina layers, $25 \mathrm{~cm}$ and $40 \mathrm{~cm}$ thick respectively, and a $32 \mathrm{~cm}$ thick white sand layer between the two previous layers). The Lago Mare Unit is followed by the silty Arenazzolo Unit (5.60 m thick) comprising 6.5 dark-light alternations (Figs. 9E, 10A). The upper part of this section corresponds to the Trubi Unit and is constituted by cyclic carbonates and marls. The position of the Zanclean GSSP, placed at the base of the Trubi Unit, is indicated on Figure 9F).

We performed new analyses of nannofossils from the Eraclea Minoa Section 1 in order to better characterize the major environmental changes affecting the Lago Mare, Arenazzolo and Trubi units. The calcareous nannoplankton identified in the Lago Mare Unit of Section 1 includes, among others taxa, Nicklithus amplificus, Amaurolithus primus, Coccolithus pelagicus, Discoaster quinqueramus, Helicosphaera carteri s.I., Helicosphaera intermedia, Pontosphaera multipora, small-sized reticulofenestrids, Reticulofenestra pseudoumbilicus, Sphenolithus group abies/moriformis, Triquetrorhabulus striatus and Triquetrorhabulus rugosus (Fig. 9E). Considering that the Sicilian Upper Evaporites which end the Sicilian Messinian evaporitic series are significantly younger than $5.96 \mathrm{Ma}$ (the robust age of the beginning of the MSC; Table 1), N. amplificus (Highest Occurrence at 5.939 Ma: Raffi et al., 2006; Fig. 4) could be 
reworked. This nannoflora, which still includes Discoaster quinqueramus (Highest Occurrence at 5.54 Ma: Raffi et al., 2006; Fig. 4), precedes Zone NN12 and hence might be related to the Subzone NN11d (Fig. 4). Londeix et al. (2007) studied dinoflagellate cysts from the successive uppermost part of the Eraclea Minoa section (Lago Mare and Arenazzolo units) and lowermost part of the classic Capo Rossello section (Fig. 9B) (lowermost Trubi). The dinoflagellate cyst assemblage of the Lago Mare Unit is dominated $(>60 \%)$ by Lingulodinium machaerophorum and Homotryblium spp (Fig. 10E) that indicates coastal to lagoonal environments (Londeix et al., 2007). The presence of Cretaceous reworked dinoflagellate cysts on top of the Lago Mare Unit results from an increased terrestrial input, and was considered to announce the huge erosional episode of the Mediterranean desiccation phase (Londeix et al., 2007). The Arenazzolo Unit is characterized by an increase in more marine dinoflagellate cysts assemblages (occurrences of Impagidinium spp.) showing fluctuations between dominant outer shelf conditions and inner shelf to coastal conditions (everywhere less than $50 \%$ coastal, apart from two incursions) (Londeix et al., 2007), documenting a significant rise of sea-level at the base followed by secondary fluctuations of sea level. The Trubi dinoflagellate cyst assemblage with Impagidinium patulum mostly documents open marine conditions (Fig. 10E). To summarize, the dinoflagellate cyst study from Eraclea Minoa (Section 1; Fig. 9E) and the nearby equivalent Capo Rossello section p.p. by Londeix et al. (2007) suggests that Lago Mare was a coastal to brackish-lagoonal environment, Arenazzolo corresponded to inner and outer shelf marine conditions, and Trubi to open marine conditions. The difference in bathymetry between Arenazzolo and Trubi might have been only 100 to $150 \mathrm{~m}$. We obtain similar results using pollen analysis (Fig. 10D) and especially the "Pinus / Halophytes" ratio (P/H). In the $\mathrm{P} / \mathrm{H}$ ratio, the increasing relative frequency of Pinus (an easily water-transported pollen grain) correlates with the increasing offshore distance, in opposition to that of halophytes (plants restricted to coastal environments) (Suc et al. 1995). We interpret the abrupt and intense changes in the pollen ratio $\mathrm{P} / \mathrm{H}$ (Fig. 10D) as indicating that the rise in sea-level preceding Arenazzolo corresponds to a significant increase in the distality at the locality. On the other hand, the continuing process of sea-level rise at the base of Trubi apparently did not coincide with an increased distality. Accordingly, palynological data (dinoflagellate cysts and pollen grains) support the interpretation that the most significant break in marine influence occurred between the Lago Mare and Arenazzolo units. We must indicate that Eastern Paratethyan dinoflagellate cysts (Galeacysta etrusca mostly) are regularly recorded from $60 \mathrm{~cm}$ above the base of Arenazzolo practically up to its top (Fig. 10E; Londeix et al., 2007; Popescu et al., 2009).

Section 2 (Fig. 9E \& G) is markedly different from Section 1: (1) the Lago Mare Unit is significantly thinner ( $1.50 \mathrm{~m}$ thick only) and truncated at its top, ending with a single residual 2 centimetre thick coquina layer rich in dreissenids, and (2) the Arenazzolo Unit (same thickness as at Section 1) clearly onlaps the Lago Mare clays (Fig. 9G) and according to our new nannofossil analyses contains typical "Pliocene" specimens, Helicosphaera selli and Discoaster asymmetricus, while Ceratolithus acutus was not recorded (Fig. 9E). We therefore conclude that the upper part of the Lago Mare of Section 1 has been eroded in Section 2, and the erosional contact between Arenazzolo and Lago Mare should correspond to the MES (Fig. 9E) and, hence, the peak of the MSC with the major sea-level drawdown.

Here, we consider that the desiccation of the Mediterranean is not expressed by intenselymarked erosion, probably because the locality occupied an interfluvial position in a semi-arid area with limited erosion and condensed sedimentation (Suc \& Bessais, 1990; Fauquette et al., 2006) as known in other peri-Mediterranean places (Vera Basin, Cuevas de Almanzora section: Clauzon, 1980b; Dardanelles Strait area, Intepe section: Melinte-Dobrinescu et al., 2009). However, evidence of significant and coeval erosion is provided by several offshore wells in the area such as Pamela 1 and by seismic profiles where Lower Pliocene deposits immediately overlie the Upper Miocene so-called Terravecchia (VI.D.E.P.I. Database: $\mathrm{fttp}: / / \mathrm{www}$.videpi.com/mappa.php). This interpretation is also supported by the new offshore data from Tunisia indicating that the dramatic sea-level drop which caused the deposition of evaporite in the Mediterranean central basins and the cutting of fluvial canyons on their margins 
occurred after the deposition of a thick marginal evaporitic succession similar to the Sicilian series (Fig. 9A; El Euch - El Koundi et al., 2009).

The 6.5 dark-light alternations observed at Section 1 within the Arenazzolo Unit (Figs. 9E, $10 \mathrm{~A}$ \& B; see also: Decima \& Wezel, 1971: fig. 9), already indicated by Brolsma (1975) at Capo Rossello resemble the precession-related carbonate cycles of the overlying Trubi (Hilgen \& Langereis, 1989). In order to clarify the cause of the dark-light alternations of the Arenazzolo Unit, we estimated its $\mathrm{CaCO}_{3}$ content by measurement of the escaped $\mathrm{CO}_{2}$ as reaction to $\mathrm{HCl}$ using a Bernard calcimeter. The values are shown in Figure 10C: on the whole, dark bands correspond to the higher carbonate contents, a more regular relation in the upper Arenazzolo. Despite variation in Arenazzolo $\mathrm{CaCO}_{3}$ only fluctuates between 15 and 25\%, at a lower level than in the Trubi (60-80\%: Hilgen \& Langereis, 1989), we speculate that the dark-light alternations can be similarly used as a chronometer to estimate by precession-tuning the age of the base of Arenazzolo.

\subsection{Maccarone (Apiro, Marche)}

The Maccarone section (Fig. $3 \& 11 \mathrm{~A}$ ) belongs to the reference area for the Apennine foredeep where reworked marginal gypsum is observable beneath a thick clayey-turbiditic series (the Di Tetto Formation) devoid of foraminifers in its larger lower part (Carloni et al., 1974; Popescu et al., 2007), i.e. the $p-e v_{1} b$ sequence of Roveri et al. (2001) (Fig. 11A). This formation is overlain by the Colombacci clay-limestone alternations and topped by the Lower Zanclean open-marine Argille Azzurre (>700 m in thickness within the foredeep, $210 \mathrm{~m}$ at Maccarone located on the edge of the foredeep) (Roveri \& Manzi, 2006). The Maccarone section benefits from three precise ages near its base and top (Fig. 11A): (1) an ash layer first dated at $5.51 \pm 0.05 \mathrm{Ma}$ using ${ }^{39} \mathrm{Ar} /{ }^{40} \mathrm{Ar}$ (Odin et al., 1997) but recently re-dated at $5.555 \pm 0.06 \mathrm{Ma}$ (Table 1; Cosentino et al., 2009) as considered in Figure 11, and (2) the evidence of the C3n.4n (i.e. Thvera) normal paleomagnetic Chron (Gennari et al., 2008), the base and top of which are respectively dated at 5.235 and 4.997 Ma (Lourens et al., 2004). As a consequence, the base of the Argille Azzurre Formation, just preceding the Sphaeroidinellopsis Acme (Zone MPI1) is reasonably dated at $5.332 \mathrm{Ma}$ by Gennari et al. (2008). This chronological calibration of the section has been recently strenghtened by Popescu et al. (2007) who recorded the first evidence of Ceratolithus acutus at $133 \mathrm{~m}$ in the section (Fig. 11A), the marker of the nannoplankton Subzone NN12b (Fig. 4) whose Lowest Occurrence is dated at $5.345 \mathrm{Ma}$ (Table 1; Raffi et al., 2006). Popescu et al. (2007) demonstrated that the water-level rise detected at ca. $110 \mathrm{~m}$ in the section (Fig. 11A) was actually caused by the entrance of marine waters into the Apennine foredeep almost coeval with the earliest influxes of Paratethyan surface waters. The above-mentioned age model of the section (Fig. 11A) allows us to propose a new cyclostratigraphy, based on the pollen record studied by Bertini (1992, 2006), which differs from that of Roveri \& Manzi (2006) and Gennari et al. (2008). We use the pollen ratio (SE/AE) "Subtropical Elements/Altitudinal Elements", i.e. mostly Taxodiaxeae plus other subtropical plants (Engelhardia, Nyssa, Arecaceae, CyrillaceaeClethraceae, etc.) vs. the Cedrus-Tsuga-Abies-Picea altitudinal forest complex (Fig. 11B). The curve expresses the amount of pollen grains of low altitude thermophilous forests (i.e. SE) relative to those of coniferous forests growing in significantly cooler conditions at higher altitude (i.e. AE). Maxima of SE in the pollen records represent spreadings of the thermophilous forests during warmer phases while maxima of $A E$ correspond to descents of the altitudinal forest belts as a response to cooler phases, making this index very useful for climate reconstructions at the foot of high mountains (Popescu, 2001). It is established that, contrarily to Late Pleistocene, the Pliocene and Early Pleistocene coolings occurred during times of high eccentricity and the warmer phases correspond to low eccentricity ( $\mathrm{Li}$ et al., 1998). This relationship was applied to a well-dated long section by Popescu (2001) and Popescu et al. (2006a) who correlated the highest values of the SE/AE ratio with minima of eccentricity and its lowest values with maxima of eccentricity. Considering the time-window 5.60-5.30 Ma corresponding to the deposition of the Maccarone section, it is worth noting that three eccentricity minima (warmer phases) appear 
at 5.592, 5.486 and 5.378 Ma respectively (Fig. 11C; Laskar et al., 2004). In-between, the highest value of the SE/AE ratio is directly correlated with the lowermost minimum of eccentricity at $5.378 \mathrm{Ma}$, consistently with the first occurrence of Ceratolithus acutus at 5.345 Ma (Fig. 11A)., and so on for the older and younger maxima and minima of SE/AE that we respectively correlate with the older and younger minima and maxima of eccentricity (Fig. 11BC).

\subsection{The Dardanelles Strait area}

In this area, two kinds of sedimentary records have been observed (Fig. 12; Melinte-Dobrinescu et al., 2009). At Intepe (Fig. 12A), an apparently continuous section (Fig. 12B), with bay to lagoon environments and a constant nannoflora allows, by using the first appearance of Ceratolithus acutus (at $5.345 \mathrm{Ma}$; Table 1) (Fig. 12B \& C), the precise location of the MSC below this point. A thin bed of lignite was observed below a thin rubefied (i.e. fired) clayey bed transformed into porcellanite. This contact (Fig. 12B \& C) has been interpreted as evidence of an emersion of the area and correlated with the peak of the MSC (Melinte-Dobrinescu et al., 2009). These authors correlated the lignite with the marginal evaporites (the first step of the MSC; Clauzon et al., 1996). But a few hundred metres northwards, Melinte et al. (2009) pointed out thick sandy foreset beds (dipping at $25^{\circ}$ to the West) of a Gilbert-type fan delta, with clayey bottomset beds exposed along the northern shoreline of the Dardanelles Strait at Seddülbahir where the first appearance of Ceratolithus acutus (i.e. at $5.345 \mathrm{Ma}$; Table 1) has been recorded (Fig. 12 B \& D). The Zanclean Gilbert-type fan delta infills a Messinian fluvial canyon (Fig. 12A \& B), where the MES was identified at several points. In both localities (Seddülbahir and Intepe), the lowermost clays just above the MES (Seddülbahir) or the Messinian subaerial exposure (Intepe) show a record of Triquetrorhabdulus rugosus which is the accurate biostratigraphic nannofossil marker (Fig. 4). Ceratolithus acutus appears above (Fig. 12B-D) (Melinte-Dobrinescu et al., 2009). Triquetrorhabdulus rugosus disappears in the upper part of the Intepe section (Fig. 12) at 5.279 Ma (Fig. 4: Raffi et al., 2006) as it also does in the upper part of the Gilbert-type fan delta bottomset beds (Fig. 12B). Melinte et al. (2009) concluded that the nannofossil succession in the post-MSC deposits in the Dardanelles Strait area, consistent with that of Figure 4, suggests a marine reflooding older than the base of the Zanclean Stage.

\subsection{A Block Formation in fluvial Messinian canyons all around the Mediterranean.}

Coarse deposits made of large cemented rounded blocks reworked from Mesozoic limestones were indicated by Clauzon (1978) directly covering the MES in the Var ria (Nice area, southeastern France) and immediately overlain by the foreset beds of the Zanclean Gilbert-type fan delta (Clauzon et al., 1990). This Block Formation is locally known as the Carros Breccia. In another place, Clauzon (1980b) described a similar formation at Garrucha near Vera (southeastern Spain) where, in an identical stratigraphic situation, gypsum blocks were deposited, being reworked from the marginal Messinian evaporites ( $1^{\text {st }}$ step of the MSC: Clauzon et al., 1996). Recently, we have identified such coarse deposits (with reworked Messinian gypsum or not) in identical stratigraphic conditions all around the Mediterranean Basin and adjacent seas as the Marmara Sea. We interpret those blocks as river-transported deposits resulting from a debris-flow process whether the fine particles have been cemented or not (Nemec, 1990). Their stratigraphic position (Fig. 2A) places them after the erosional peak of the MES and prior to the marine sediments of the Gilbert-type fan delta. We are unable at this state of the paper to determine if they were deposited in subaerial or submarine conditions, i.e. at the end of the erosional phase or just after the sudden reflooding. According to the literature and mostly to our field observations, about 20 localities displaying such deposits are now recorded; they are shown in the "Discussion" section. In some localities such as at Carros, the cemented blocks are covered by an iron-rich crust (Fig. 2B), the significance of such a chemical sedimentation being unclear (subaerial water-table iron pan or submarine microbialite?). 


\section{Discussion}

\subsection{A two-step reflooding in the Gulf of Lions}

The MES, characterized by a badland morphology (Ryan, 1978), has long been interpreted as a subaerial erosional surface (Ryan and Cita, 1978; Gennesseaux \& Lefebvre, 1980; Gorini, 1993; Guennoc et al, 2000; Dos Reis, 2001; Dos Reis et al, 2005, 2008; Lofi et al, 2003, 2005). The planation surface "e" (Figs. 5 - 7) observed seaward the MES, has recently been interpreted as being related to wave erosion at the end of the Messinian Salinity Crisis (Bache, 2008; Bache et al., 2009). This interpretation is supported by the smooth aspect of surface "e" over a large horizontal distance, by the erosional truncations of the underlying series, and also by the onlap termination of the overlying series (Figs. $5,-7$ ) which are characteristic features of transgressive surfaces (Cattaneo \& Steel, 2003; Catuneanu, 2006). Past analogues of such transgressive surfaces are known in southeastern France (Champion et al., 2000). These surfaces, related to Miocene transgressions, present an almost horizontal smooth morphology over large distance (Figs. 13A \& B) which may be compared with the planation surface "e" highlighted in this study.

Wave erosion is essentially contained between the surf zone and the limit of fair-weather wave base which is usually between 10 and 20 m (Demarest \& Kraft, 1987; Abbott, 1998; Catuneanu, 2006) and can reach up to $40 \mathrm{~m}$ in the case of extreme wave energy as in the Canterbury Plains in New Zealand (Leckie, 1994). Sunamura (1987) also calculated a maximum theoretical depth of $40 \mathrm{~m}$ offshore Japan. In the case of extreme storm waves, the wave base can reach 70 $\mathrm{m}$ to maximum depth of $200 \mathrm{~m}$ in the Irish Sea and Newfoundland (Cattaneo \& Steel, 2003; Guillocheau et al., 2009). Consequently, surfaces abraded by wave ravinement during a landward shift of the shoreline can be used to estimate the associated increase in bathymetry. For that purpose, we need to estimate their slope value just after their formation (see below the "Quantification of the two steps" section).

Storm events can erode clean sands from the shoreface and deposit them further offshore (between the fair-weather wave-base and the storm wave base). These deposits are often enriched in micas and intercalated between offshore silty-clay deposits (Guillocheau et al., 2009). The 50 meters of azoic deposits found in GLP2 well (Fig. 8), corresponding to an alternation of fine to medium micaceous sandstone with subrounded to subangular grains and silty calcareous clays, could be the result of such events. In the Gulf of Lions, wave action has thus reworked the previous deposits and also reshaped the subaerial unconformity into a typical planation surface. This early transgression must have been relatively slow to enable wave erosion, removal of material and smoothing of the surface.

The contact between badland morphology and the planation surface "e", at constant TWTT depth in the whole Gulf of Lions (Fig. 7), has been interpreted as the location of the paleoshoreline at the end of the wave erosion phase and just before the very rapid reflooding of the Mediterranean (Bache, 2008; Bache et al., 2009). Numerous representative analogues of this situation can be found in areas where wave action affects the present-day shoreline (Figs. $13 C \& D)$.

A major transition in the variations of the relative sea level and a two-step reflooding can thus be proposed. First, a slow landward migration of the shoreline smoothed the distal subaerial reliefs of the deepest part of the MES, and reworked previous regressive deposits (Step I; Fig. 5 ); and second, a very rapid reflooding "froze" the remaining subaerial surface (MES) without further erosion or deposition (Step II; Fig. 5). This second relative sea-level rise was so rapid that the eroded shelf has been suddenly out of the range of wave action. 


\subsection{May the two-step reflooding be extended to the scale of the entire Mediterranean?}

The evidence of Gilbert-type fan deltas within several Zanclean rias (Dardanelles area as reminded above: Melinte-Dobrinescu et al., 2009; Antalya Basin in southwestern Turkey: Poisson et al., 2011; many other localities that some of us observed in the northern Aegean, Cyprus and Syria) suggests that the two Mediterranean basins reflooded in a similar way One question that arises about the slow reflooding (Step I) is whether it is only restricted to the Western Mediterranean (Provence-Algiers Basin) or whether it concerned the whole Mediterranean Basin. A comparable flat ravinement surface had been identified in the Levantine Basin and ascribed to wave erosion (Bertoni \& Cartwright, 2006: see seismic profile of fig. 14 and text p. 112). Such a surface can also be observed off the Nile Delta in the interfluves bordering the Abu Madi canyon, where it contrasts sharply with the lowermost part of the canyon fill (Dalla et al., 1997).

As a consequence, another question arises and concerns the Sicily sill which today separates the two Mediterranean basins (ca. $100 \mathrm{~m}$ in bathymetry: Fig. 14, profile AB) and controls their water exchanges (Astraldi et al., 1999). Paleotectonic reconstructions (Jolivet et al., 2006) suggest that a wider space existed between Tunisia and the Italian Peninsula during the Tortonian and early Messinian times before the opening of the South Tyrrhenian Sea in the Pliocene and subsequent appearance of the Etna volcano in the Mid-Pleistocene. But the precise limits and the depth of this probably wider strait are difficult to estimate although it was likely much deeper than today. The map shown in Figure 15 gives a hypothetical idea about the paleogeography of the Mediterranean and surrounding regions at the end of Step I of reflooding despite the lack of information on the paleoshoreline location other than for the Gulf of Lions (Fig. 6).

\subsection{Tentative age model of the reflooding process and suggested resulting paleogeographic changes}

If the paleogeography at the end of Step I of reflooding is highly hypothetical (Fig. 15), that after Step II is well-controlled as mapping the early Zanclean marine deposits is achieved inland (see the most recent map published by Jolivet et al. (2006)). The map after Step II (Fig. 16) has been significantly completed thanks to some recent publications (Soria et al., 2008; Clauzon et al., 2009; El Euch - El Koundi et al., 2009; Melinte et al., 2009; Poisson et al., 2011) and to the intensive field investigations of some of us (G.C., J.-P.S., J.-L.R., L.M.).

The above-mentioned data collected in Sicily (Eraclea Minoa), in the Apennine foredeep (Maccarone) and in the Dardanelles Strait support that the reflooding of the Mediterranean Basin (i.e. Step II) was completed significantly before $5.332 \mathrm{Ma}$ (Zanclean GSSP) as suggested by previous papers (Cavazza \& DeCelles, 1998; Cornée et al., 2006). Using cyclostratigraphy and astrochronology, it is possible to date this event in Sicily and in the Apennine foredeep. If we apply to the 6.5 dark - lights alternations of the Arenazzolo Unit the same quasi-period as evidenced in the Trubi (i.e. $20 \mathrm{kyrs}$ ), its duration should be of about $130 \mathrm{kyrs}$. That would date its base, and hence Step II of the Mediterranean reflooding, at 5.46 Ma (Table 1), an age consistent with the basal bottomset beds of the Dardanelles Gilbert-type fan delta preceding the first appearance of Ceratolithus acutus (Fig. 12B) dated at $5.345 \mathrm{Ma}$ (Fig. 4). In the Apennine foredeep, using the established relationship between the pollen ratio $\mathrm{SE} / \mathrm{AE}$ and eccentricity (Fig. 11B \& C), the arrival of marine waters at Maccarone can be dated at $5.36 \mathrm{Ma}$ (Fig. 11; Table 1; Popescu et al., 2007). The slightly delayed entrance of marine waters into the Apennine foredeep is consistent with its potential status as an isolated perched freshwater basin during the peak of the MSC (Fig. 1) (Clauzon et al., 1997, 2005). 
Dating and duration of Step I of reflooding are at the moment impossible to estimate. It is constrained between $5.60 \mathrm{Ma}$, the consensual age of the sea-level drawdown in the Mediterranean (CIESM, 2008) and the above-proposed age at 5.46 Ma for the sudden Step II of reflooding. Another key-age can be deduced from the dating of the base of the Arenazzolo Unit at 5.46 Ma: the first influx of Paratethyan waters after the MSC at $5.45 \mathrm{Ma}$ (Table 1) indicated by dinoflagellate cysts half a dark - light cycle above the base of Arenazzolo (Fig. 10E).

With respect to the available ages (Table 1), it is possible to propose interpretative paleogeographic maps at successive times between $5.46 \mathrm{Ma}$ and $5.30 \mathrm{Ma}$. At $5.46 \mathrm{Ma}$, fluvial canyons were suddenly filled by marine waters which transformed them into rias but the connection which existed with the Dacic Basin prior to the MSC through the Balkans (Popescu et al., 2009) has not been re-established (Fig. 16). In many places, a Block Formation (with or without reworked Messinian marginal evaporites) is sandwiched between the MES and Gilberttype fan delta deposits as shown on Figure 2A. Such deposits have been interpreted as submarine slumps caused by dissolution and collapse (Los Feos, Nijar Basin: Fortuin \& Krijgsman, 2003) or as an olitostrome representative of enigmatic tectonics (Garrucha, Vera Basin: Ott d'Estevou et al., 1990). We suggest that they are river-transported coarse deposits as shown by Breda et al. (2007). The two-step reflooding allows the emplacement of these debris-flow deposits between the end of the drawdown and the beginning of Step II just after the sudden entrance of marine waters into the proximal part of canyons, completely changing the base-level and stream power of the rivers which become incapable of transporting such blocks. The block deposits are then capped by the arrival of the first prograding sediments of the Gilbert-type fan deltas.

Figure 17 illustrates the re-connection of the Dacic Basin with the Mediterranean at $5.45 \mathrm{Ma}$ (Table 1) attested by dinoflagellate cysts in the Sicilian Arenazzolo Unit (Fig. 10E). This is consistent with the results of Popescu et al. (2006b) who obtained an astronomic age of ca. $5.40 \mathrm{Ma}$ at the exposed base of bottomset beds of the Zanclean Gilbert-type fan delta at Turnu Severin (SW Romania). As previously suggested by (1) the results obtained by MelinteDobrinescu et al. (2009) in the Dardanelles area and (2) the presence of two opposed fluvial networks in the region (Suc et al., 2009), the gateway re-connecting the Mediterranean with the Eastern Paratethys was not located in the region of the Marmara Sea. After exploring all the sedimentary basins in the Balkans area, a gateway passing at Serres and Skopje (i.e. in the area drained today by the Strymon-Vardar River), then at Niš before joining the Dacic Basin (i.e. in the area drained today by the Timok River) has been suggested (Clauzon et al., 2005; Popescu et al., 2009; Suc et al., 2009) as shown in Figure 17. Such a gateway is supported by our recognition of three illustrative Zanclean Gilbert-type fan deltas nested within Miocene deposits, respectively close to:

Serres (at Ano Metochi; Fig. 18A), dated by mollusks (abundant Pecten benedictus and Ostrea lamellose: Karistineos \& Georgiades-Dikeoulia, 1985-86) in agreement with the pollen flora (rich in Taxodiaceae, Liquidambar, Zelkova, Cathaya, Cedrus, Picea, etc.) that we found in the bottomset beds similar to those from the other welldated pollen localities in the region (Biltekin, 2010);

- Skopje (in the Draĉevo - Batinci area; Clauzon et al., 2008), dated by the nannofossil Ceratolithus acutus (Figs. 18 B \& C);

- Niš (at Gabrovaĉka Reka), dated by nannofossils (Ceratolithus acutus and Triquetrorhabdulus rugosus) (Fig. 18D).

The delayed invasion of Mediterranean waters into the Dacic Basin was probably caused by the crossing of a sill, here called the Balkans sill, which we tentatively locate east of Skopje (Fig. 17). At Draĉevo (Skopje), the marine-continental transition of the Gilbert-type fan delta, i.e. the 
marker of the early Zanclean coastline, is today at $395 \mathrm{~m}$ altitude (Clauzon et al., 2008). This value provides an idea of the post-Pliocene uplift (Fig. 14, profile CD).

On the basis of the eccentricity tuning of the pollen record from the Maccarone section, it is possible to date at $5.36 \mathrm{Ma}$ the arrival of marine waters into the Apennine foredeep (Fig. 11) and hence the re-connection of this lake with the Mediterranean Sea (Fig. 19). The Pelagosa high was probably the obstacle which isolated this lake during the peak of the MSC (instead the Otranto high proposed by Clauzon et al., 2005). This is supported by the evidence of the Colombacci Formation (affected by influxes of marine waters) only to the north of the Gargano Peninsula (which today is the coastal expression of the Pelagosa sill; Fig. 14, profile Cd). This assumption is in agreement with the presence of marine fishes within the Colombacci Formation in the region of Ancona (Carnevale et al., 2006). The Pelagosa sill is today $160 \mathrm{~m}$ deep (Fig. 14, profile CD; Gaĉić et al., 2002). At that time, marine waters had not yet invaded the entire Po Plain (Fig. 19; Mary et al., 1993; Channell et al., 1994; Sprovieri et al., 2007; Violanti et al., 2011).

Finally, the Mediterranean waters crossed the Scythian sill (Fig. 20), i.e. the Reni sill of Semenenko (1995), today exposed in the Dobrogea region (Fig. 14, profile CD). Incursion of Mediterranean species (diatoms: Schrader, 1978; dinoflagellate cysts: Popescu, 2006; calcareous coccoliths including Ceratolithus acutus and Triquetrorhabdulus rugosus: Popescu et al., 2010) into the Euxinian Basin is documented by DSDP Site 380 (Fig. 3). It occurred at $5.31 \mathrm{Ma}$ (Table 1; Fig. 20) as established by cyclostratigraphy (Popescu et al., 2010).

Why did these peripheral (Dacic, Apennine and Euxinian) basins not re-connect simultaneously to the Mediterranean at the time of the sudden Step II of the reflooding? Probably because of the presence of sills at different altitude which were successively inundated during the continuing slower global rise of sea level after $5.46 \mathrm{Ma}$ by the end of the late Miocene Antarctic glaciation (Hardenbol et al., 1997; Miller et al., 2005). The minimum $50 \mathrm{~m}$ water depth increase between 5.46 and 5.332 Ma could explain the sedimentological differences between the Arenazzolo (prodeltaic muds) and Trubi (white chalky pelagic oozes) units, also reflected by their respective dinoflagellate cysts content (Fig. 10E).

\subsection{What happened at Gibraltar?}

Today, the water circulation within the Mediterranean Sea is controlled by sills and, mostly, by the sill of Gibraltar (Bethoux \& Gentili, 1999). Accordingly, what happened at the Strait of Gibraltar is crucial to unravelling the process of the Mediterranean reflooding after the MSC. The erosional activity of the Atlantic flow after an early erosion by a local river (Blanc, 2002) as was modelled by Loget et al. (2005) has been proposed in contrast to the Gibraltar paleo-falls (Hsü et al., 1973) or a major tectonic event (Krijgsman \& Garcés, 2004). This is supported by the distance of $30 \mathrm{~km}$ which separates the strait from the sill that shifted westward as a consequence of this erosion. Recently, Garcia-Castellanos et al. (2009) proposed that the Atlantic flow directly cut the Gibraltar channel in a cataclysmic way. Campillo et al. (1992) and then Garcia-Castellanos et al. (2009) documented the presence in the central Alboran Sea of a major paleo-channel wich constitutes the relic of a major gateway between the Atlantic Ocean and the Mediterranean Basin.

Step I of reflooding relates to an early stage of (subaerial or marine) erosion at Gibraltar resulting in the entrance of Atlantic waters in moderate quantity whatever its proposed duration (26 yrs: Blanc, 2002; 100 to 3,000 yrs: Garcia-Castellanos, 2009), that anyway appears greatly insufficient in regard to the events that occurred during this time-interval: 
- as a consequence of the erosion at Gibraltar, the volume of entering Atlantic waters should have progressively increased; we estimate that the total volume of water in the Mediterranean Basin at the end of Step I could represent $25 \%$ of its capacity;

- in the same way, the progressive sea-level rise would form the planation surface.

Step II of reflooding (Fig. 16) is the sudden, fast and massive entrance of Atlantic waters into the Mediterranean Basin as the immediate response to the collapse of the sill suggested by Blanc (2002) and Garcia-Castellanos et al. (2009), with similar proposed duration (respectively 10-11 yrs and a few months to 2 yrs). Mediterranean physiography at the time when this rush started is sketched out in Figure 15. After a rough estimate, including a final catastrophic sealevel rise of $600-900 \mathrm{~m}$, we conclude that ca. $50 \%$ of the water volume of the Mediterranean Basin entered it just after the collapse as opposed to the $90 \%$ proposed by Garcia-Castellanos et al. (2009).

The floor topography of the Western Alboran Basin as deduced from seismic lines and structural maps (Alvarez-Marrón, 1999; Comas et al., 1999; Mauffret et al., 2007) seems to have been made of successive small basins at decreasing altitudes from West to East and still infilled by marine waters during the peak of the MSC, into which the Atlantic continuously overflowed, feeding the abyssal plains farther East after their almost complete desiccation. Such a physiography could explain how the Mediterranean biota (molluscs, echinids, bryozoans, etc.) recovered so quickly after the crisis from some Alboran potential refuge basins, providing a possible response to this nagging question pointed out by paleontologists (Néraudeau et al., 2001; Néraudeau, 2007). This hypothesis is expressed on the map of Figure 1. Collapse at Gibraltar would have occurred at $5.46 \mathrm{Ma}$, probably as hypothesized by Blanc (2002) as the result of a significant threshold in the erosion intensity. At that time, the Atlantic water channel through the Gibraltar area would suddenly become a wide strait and the sill would have acquired its approximate present-day morphology. The flow of Atlantic waters across the basins of the sill would have instantaneously supplied the entire Mediterranean Sea with preserved marine endemic benthic organisms.

\subsection{Quantification of the two steps}

The increase in bathymetry during the two steps of reflooding can be estimated. For this purpose, the paleoshoreline identified between the badland morphology and the planation surface " $e$ " provides a distinct point of reference. The paleoshoreline is located at a present-day depth of 1.6 seconds (TWTT) in the whole Gulf of Lions margin (Fig. 5). We estimate this point at a depth between $1800 \mathrm{~m}$ and $2100 \mathrm{~m}$ taking into account the seismic velocities (Sonic from e-logs) and respective depths found in the nearby Autan1 and Rascasse boreholes. The original depth of the paleoshoreline can be estimated by subtracting the Pliocene and Quaternary subsidence from its present-day depth (Fig. 21). Rabineau et al (2006), using Pliocene and Quaternary geometries on the shelf, estimated this subsidence at around $\sim 215 \mathrm{~m} / \mathrm{Ma}$ at $\sim 62 \mathrm{~km}$ from the coast in the same area. Considering the age of 5.46 Ma for the end of Step I of reflooding (Table 1 and above), $\sim 1200 \mathrm{~m}$ of subsidence are obtained at this point. We can conclude that the paleoshoreline was located between $600 \mathrm{~m}(1800-1200 \mathrm{~m})$ and $900 \mathrm{~m}(2100-$ $1200 \mathrm{~m}$ ) below the present sea level at 5.46 Ma. The paleoshoreline represents the seaward boundary of the MES which has been preserved during the second step of reflooding. The rapid increase in bathymetry during this second reflooding step was thus between 600 and $900 \mathrm{~m}$.

The increase in bathymetry during the first step of reflooding may also be estimated. We have thus deduced the initial depth of the seaward limit of observation of the planation surface "e". This point is located at a maximum distance of $112 \mathrm{~km}$ from the coast, around 3 seconds (TWTT). We also estimated its depth taking into account the respective velocities and depths of the GLP2 well and ESP 202 seismic profile. This gave a depth of between 3000 and $3400 \mathrm{~m}$. 
Extrapolating the total subsidence calculated by Rabineau et al. (2006) towards the basin with a linear trend (Fig. 21), we obtain a total subsidence of $\sim 430 \mathrm{~m} / \mathrm{Ma}$ at $\sim 112 \mathrm{~km}$ from the coast. Considering the age at $5.46 \mathrm{Ma}$ (Table 1), a subsidence of $\sim 2300 \mathrm{~m}$ is obtained at this point. This limit was thus localized between $700 \mathrm{~m}$ (actual depth: 3000-2300 m) and $1100 \mathrm{~m}$ (actual depth: 3400-2300 m) below the present sea level at 5.46 Ma. The shoreline displacement, during which the planation surface "e" formed (Step I), occurred between two points respectively located at 1.6 seconds TWTT (600 to $900 \mathrm{~m}$ ) and 3 seconds TWTT (700 to $1100 \mathrm{~m}$ ) depth before the onset of the Pliocene subsidence. The maximum increase in bathymetry during this step was thus around $500 \mathrm{~m}(1100-600 \mathrm{~m})$ and the corresponding maximum slope value of the planation surface " $e$ " was $1 \%$. This estimate was made considering an extrapolation of the shelf tilting towards the basin as calculated by Rabineau et al. (2006), and it is thus a maximum value. Assuming that the minimum value of this slope was $0 \%$, the total increase in bathymetry for the two-step reflooding is estimated between $600 \mathrm{~m}(600 \mathrm{~m}$ for the first step and $0 \mathrm{~m}$ for the second step with a slope value of $0 \%$ ) and $1100 \mathrm{~m} \mathrm{(600} \mathrm{m} \mathrm{for} \mathrm{the} \mathrm{first} \mathrm{step} \mathrm{and} 500 \mathrm{~m}$ for the second step) in the earliest Pliocene. A relative sea-level curve can be proposed for the Gulf of Lions according to this calculation (Fig. 22).

The rate of sea-level rise for the second step of the post-MSC reflooding can be estimated around $60 \mathrm{~m} / \mathrm{kyr}$ (at least $600 \mathrm{~m}$ in at most 10,000 years). This high rate shows that this transgression was catastrophic and must be related to a special event at Gibraltar (see above). Due to uncertainties on the timing of the first step of reflooding, the corresponding rate cannot be estimated. However, contrasted rates for the two steps of the post-MSC reflooding may explain why the rugged regressive MES has been preserved landward of 1.6 seconds TWTT and erased by wave erosion seaward of it.

Deposition of the central evaporites (Lower, Mobile and Upper units: Lofi et al., 2011; total thickness: up to $2,800 \mathrm{~m}$ ) requires a continuous input of marine water at the beginning of Step I of reflooding, before the brine concentration reached a critical threshold (Fig. 22). However, it is not excluded that some halite deposited earlier, i.e. during the sea-level drawndown, and was mixed with detrital deposits. In fact, it can be assumed that two phases are distinguishable and in close succession (Bache et al., 2009): (1) the main erosion phase coeval with the sea-level drop and deposition of detrital material in the almost desiccated basin; (2) deposition of the major part of evaporites during the beginning of Step I of reflooding, a phase during which fluvial erosion continued on lands and margins. Using modelling, Govers (2009) suggested that most of the evaporites were deposited before sea-level drop. Our data contradict this conclusion because the MES and related detrital products underlie the central basin evaporites (Bache et al., 2009; Montadert et al., 2010) which thus formed after the sea-level lowering. Also using modelling, Meijer \& Krijgsman (2005) concluded that there were repeated desiccations and refillings of the Mediterranean, based on the supposed correspondence of the exposed Sicilian Upper Evaporites and the Upper Unit in the central basins. We oppose this hypothesis too on the basis of the observed relationships between seismic units in the central basins (Bache et al., 2009; Montadert et al., 2010). Duration of evaporite deposition in the central basins, especially the thick halite, was probably brief (less than 50,000 yrs in our scenario) in agreement with general assumptions (Lugli et al., 2008) but impossible to define more precisely (Fig. 22).

The transition from massive halite to the Upper evaporitic Unit marks the dilution of Mediterranean waters that increased during the following "dilution event", generally pointed out as belonging to the "Lago Mare" episode (Cita et al., 1990; laccarino \& Bossio, 1999; Rouchy et al., 2001), an assumption clarified by Clauzon et al. (2005) who distinguished two kinds of "Lago Mare" episodes which occurred during three major distinct events (Fig. 22). Two of these socalled "Lago Mare" events correspond with surface water exchanges between the Mediterranean and Dacic Basin (Eastern Paratethys) through the Balkans gateway, attested by Mediterranean nannoplankton in the Dacic Basin (Drivaliari et al., 1999; Clauzon et al., 2005; Snel et al., 2006) and conversely Paratethyan dinoflagellate cysts in the Mediterranean (Londeix et al., 2007; Popescu et al., 2007, 2009). Such events, called "Lago Mare" 1 and 3 , 
occurred during high sea-levels, respectively just before the desiccation phase and just after Step II of reflooding (Fig. 22). In some exposed sections, they can follow each other in a pseudo-stratigraphic continuity, such as at Eraclea Minoa (Fig. 9E; Londeix et al., 2007; Popescu et al., 2009) and Intepe (Fig. 12B; Melinte-Dobrinescu et al., 2009). "Lago Mare" 2 is known as a brief dilution event which seems to characterize the central basins only. Being evidenced by ostracods and geochemical measurements only (see, for example: Pierre et al., 2006), it could correspond to increased run-off preceding more significant marine water input. Its duration is unknown and these sediments necessitate new researches, especially to complete their paleobiological content, for deciphering their exact origin.

\section{CONCLUSION}

Considering offshore observations in the Gulf of Lions, a two-step reflooding of the Western Mediterranean Basin is proposed for the end of the Messinian Salinity Crisis (Fig. 22):

- $\quad$ Step I $(5.56$ ? $-5.46 \mathrm{Ma})$ is characterized by a relatively moderate and slow sea-level rise $(500 \mathrm{~m}$ at the most) leading to the landward migration of the shoreline. This first transgression, which was accompanied by the planing effect of waves and tides, flattened previous highs and formed a remarkable ravinement surface. It resulted from the beginning of a progressively increasing erosion of the Gibraltar barrier.

Step II (instantaneous at $5.46 \mathrm{Ma}$ ) was particularly sudden and dramatic, resulting from the collapse of the Gibraltar channel. It caused the so-called "Pliocene Deluge", being dated prior to the Zanclean GSSP by onshore studies. This violent sea-level rise of 600$900 \mathrm{~m}$ flooded the largest part of fluvial canyons which were suddenly transformed into rias (as attested by numerous Gilbert-type fan deltas), contributing to preserve the Messinian Erosional Surface all around the Mediterranean and the paleoshoreline evidenced in the Gulf of Lions.

Such a scenario seems to have also been the case in the Eastern Mediterranean Basin, which requires more detailed research. It should be noted that this process of Mediterranean reflooding in two steps after the Messinian Salinity Crisis is consistent with all the debated scenarios of this dramatic episode.

We suggest that central basin evaporites were mostly deposited during the beginning of Step I of reflooding. After Step II of rapid Atlantic reflooding of the Mediteranean, sea-level rise slowly but regularly continued as a result of the global rise in sea-level and the successive connections between the Mediterranean and the Dacic Basin (at $5.45 \mathrm{Ma}$ ), the Adriatic foredeep (at 5.36 $\mathrm{Ma}$ ), the Euxinian Basin (at 5.31) and finally the Po Plain were established.

In summary, the events occurred during the Messinian Salinity Crisis appear to have been characterized by high complexity, some being synchronous at the scale of the entire Mediterranean, others diachronous with respect to environmental or regional conditions such as the so-called "Lago Mare" events which had a dual nature.

Many new geological aspects may be addressed as a consequence of this work. First of all, the key-surfaces observed in the Gulf of Lions provide remarkable points of reference. It will be necessary to correlate them at the scale of the whole Western Mediterranean, as well as within the Eastern Basin. Secondly, as two-step reflooding of the Mediterranean has never been considered before, the quantification of the steps will constrain future models of reflooding as well as subsidence studies (post-Messinian vertical movements). Finally, kinematic studies can be done to confirm the existence of Messinian sills within the Mediterranean Basin (Sicily Tunisia area for example) and their influence on its reflooding history. 


\section{Acknowledgements}

A. Di Stefano (Univ. Catania) provided some information on nannoplankton from Eraclea Minoa. Positive comments on the manuscript were suggested by J. Lofi. Two reviewers, W. Cavazza and an anonymous one, and the Editor of Basin Research, P. van der Beek, are greatly acknowledged for their scrupulous examination of our manuscript and their comments and recommendations which helped us to significantly improve it. We also thank Rick Herzer for his language corrections and comments on the manuscript. This work is a contribution to ANR "EGEO" Project, to CNRS/INSU "Actions Marges" Project (AMEDITER), and to "Bassins néogènes et manteau en Méditerranée" (TerMEx CNRS/INSU).

\section{References}

ABBOTT, S.T. (1998) Transgressive systems tracts and onlap shellbeds from mid-Pleistocene sequences, Wanganul Basin, New Zealand.. J. Sedim. Res., 68, 253-268.

ALVAREZ-MARRÓN, J. (1999) Pliocene to Holocene structure of the Eastern Alboran Sea (Western Mediterranean). In: Leg 161 (Ed. by R. Zhan, M.C. Comas \& A. Klaus), Proc. Ocean Drill. Progr., 161, 345-355.

AMBERT, P. (2011) Messinian and Pliocene continental formations in the Montpellier region and their geological context: geodynamic consequences in the Georges Clauzon model (1996). Bull. Soc. géol. France, 182, 2, 79-85.

AMBERT, P., AGUILAR, J.-P. \& MICHAUX, J. (1998) Evolution géodynamique messinopliocène en Languedoc central: le paléo-réseau hydrographique de l"orb et de l'Hérault (Sud de la France). Geodin. Acta, 11, 2-3, 139-146.

ASTRALDI, M., BALOPOULOS, S., CANDELA J., FONT, J., GACIC, M., GASPARINI, G.P., MANCA, B., THEOCHARIS, A. \& TINTORÉ, J. (1999) The role of straits and channels in understanding the characteristics of Mediterranean circulation. Progr. Oceanogr., 44, 65-108.

BACHE, F. (2008) Evolution Oligo-Miocène des marges du micro océan Liguro-Provençal. PhD Thesis, Université de Bretagne Occidentale, Brest. http://tel.archives-ouvertes.fr.

BACHE, F., OLIVET, J.-L., GORINI, F., RABINEAU, M., BAZTAN, J., ASLANIAN, D. \& SUC, J.P. (2009) Messinian Erosional and Salinity Crises: View from the Provence Basin (Gulf of Lions, Western Mediterranean). Earth Planet. Sci. Lett., 286, 139-157.

BACHE, F., OLIVET, J.-L., GORINI, F., ASLANIAN, D., LABAILS, C. \& RABINEAU, M. (2010) Evolution of rifted continental margins: the case of the Gulf of Lions (Western Mediterranean Basin). Earth Planet. Sci. Lett., 292, 345-356.

BENTZ, F.P. \& HUGHES, J.B. (1981) New Reflection Seismic Evidence of a Late Miocen e Nile Canyon. In: The Geological Evolution of the River Nile (Ed. by R. Said), Appendix C, SpringerVerlag, new York - Heidelberg - Berlin, 131-146.

BERGGREN, W.A., KENT, D.V., SWISCHER III, C.C. \& AUBRY, M.-P. (1995). A revised Cenozoic geochronology and chronostratigraphy. In: Geochronology, Time Scales and Global Stratigraphic Correlation: A Unified Temporal Framework for an Historical Geology (Ed. by W.A. Berggren, D.V. Kent, M.-P. Aubry \& J. Hardenbol, 54, Spec. Publ., Soc. Econ. Paleontol. Mineral., 141-212.

BERTINI, A. (1992) Palinologia ed aspetti ambientali del versante Adriatico dell"Appennino centro-settentrionale durante il Messiniano e lo Zancleano. PhD Thesis, University of Florence.

BERTINI, A. (2006) The northern Apennines palynological record as a contribute for the reconstruction of the Messinian palaeoenvironments. Sedim. Geol., 188-189, 235-258.

BERTONI, C. \& CARTWRIGHT, J.A. (2006) Controls on the basinwide architecture of late Miocene (Messinian) evaporites on the Levant margin (Eastern Mediterranean). Sedim. Geol., 188-189, 93-114.

BESSIS, F. (1986) Some remarks on the study of subsidence of sedimentary basins: Application to the Gulf of Lions margin (Western Mediterranean). Mar. Pet. Geol., 3, 37-63. 
BETHOUX, J.P. \& GENTILI, B. (1999) Functioning of the Mediterranean Sea: past and present changes related to freshwater input and climate changes. J. Mar. Syst., 20, 33-47.

BILTEKIN, D. (2010) Vegetation and climate of North Anatolian and North Aegean region since $7 \mathrm{Ma}$ according to pollen analysis. PhD Thesis, Université Claude Bernard - Lyon 1 and Istanbul Technical University.

BLANC, P.-L. (2002) The opening of the Plio-Quaternary Gibraltar Strait: assessing the size of a cataclysm. Geodin. Acta, 15, 303-317.

BOCCALETTI, M., CIARANFI, N., COSENTINO, D., DEIANA, G., GELATI, R., LENTINI, F., MASSARI, F., MORATTI, G., PESCATORE, T., RICCI LUCCHI, F. \& TORTORICI, L. (1990) Palinspastic restoration and paleogeographic reconstruction of the peri-Tyrrhenian area during the Neogene. Palaeogeogr., Palaeoclimatol., Palaeoecol., 77, 41-50.

BONADUCE, G. \& SGARRELLA, F. (1999) Paleoecological interpretation of the latest Messinian sediments from southern Sicily (Italy). Mem. Soc. Geol. It., 54, 83-91.

BREDA, A., MELLERE, D. \& MASSARI, F. (2007) Facies and processes in a Gilbert-delta-filled incised valley (Pliocene of Ventimiglia, NW Italy). Sedim. Geol., 200, 31-55.

BROLSMA, M.J. (1975) Lithostratigraphy and foraminiferal assemblages of the MiocenePliocene transitional strata of Capo Rossello and Eraclea Minoa (Sicily, Italy). Proc. Kon. Neder. Akad. Van Wetensch., ser. B, 78, 341-380.

BROLSMA, M.J. (1978) Quantitative foraminiferal analysis and environmental interpretation of the Pliocene and topmost Miocene on the South coast of Sicily. Utrecht Micropaleontol. Bull., 18, 1-143.

BURRUS, J. (1989) Review of geodynamic models for extensional basins; the paradox of stretching in the Gulf of Lions (northwest Mediterranean). Bull. Soc. géol. France, 8, 377-393.

BUTLER, R.W.H., LICKORISH, W.H., GRASSO, M., PEDLEY, H.M. \& RAMBERTI, L. (1995) Tectonics and sequence stratigraphy in Messinian basins, Sicily: Constraints on the initiation and termination of the Mediterranean salinity crisis. Geol. Soc. Am. Bull., 107, 4, 425-439.

CAMPILLO, A.C., MALDONADO, A. \& MAUFFRET, A. (1992). Stratigraphic and Tectonic Evolution of the Western Alboran Sea: Late Miocene to Recent. Geomar. Lett., 12, 165-172.

CARLONI, G.C., FRANCAVILLA, F., BORSETTI, A.M., CATI, F., D"ONOFRIO, S., MEZZETTI, R. \& SAVELLI, C. (1974) Ricerche stratigrafiche sul limite Miocene-pliocene nelle Marche centro-meridionali. Giornale di Geologia, ser. 2a, 39, 2, 363-392.

CARNEVALE, G., CAPUTO, D. \& LANDINI, W. (2006) Late Miocene fish otoliths from the Colombacci Formation (Northern Apennines, Italy): Implications for the Messinian "Lago-mare" event. Geol. J., 41, 1-19.

CASERO, P. (2004) Structural setting of petroleum exploration plays in Italy. Ital. Geol. Soc., Spec. Vol., 189-199.

CATTANEO, A. \& STEEL, R.J. (2003) Transgressive deposits: a review of their variability. Earth-Sci. Rev., 62, 3-4, 187-228.

CATUNEANU, O. (2006) Principles of Sequence Stratigraphy (First Edition). Elsevier, Amsterdam.

CAVAZZA, W. \& DECELLES, P.G. (1998) Upper Messinian siliciclastic rocks in southeastern Calabria (southern Italy): palaeotectonic and eustatic implications for the evolution of the central Mediterranean region. Tectonophysics, 298, 223-241.

CHAMPION, C., CHOUKROUNE, P. \& CLAUZON, G. (2000) La déformation post-miocène en Provence Occidentale. Geodinamica Acta, 13, 67-85.

CHANNELL, J.E.T., POLI, M.S., RIO, D., SPROVIERI, R. \& VILLA, G. (1994) Magnetic stratigraphy and biostratigraphy of Pliocene "argille azzurre" (Northern Apennines, Italy). Palaeogeogr., Palaeoclimatol., Palaeoecol., 110, 83-102.

CHUMAKOV, I.S. (1967) Pliocene and Pleistocene deposits of the Nile Valley in Nubia and Upper Egypt (in Russian). Transactions Geol.. Inst. Acad. Sci. USSR, 170, 5-111.

CHUMAKOV, I. (1973) Geological history of the Mediterranean at the end of the Miocene-the beginning of the Pliocene according to new data. In: Leg 13 (Ed. by W.B.F. Ryan, K.J. Hsü et al.), Init. Rep. Deep Sea Drill. Proj., 13, 2, 1241-1242.

CIESM (ANTÓN, J., ÇAĞATAY, M.N., DE LANGE, G., FLECKER, R., GAULLIER, V., GUNDECIMERMAN, N., HÜBSCHER, C., KRIJGSMAN, W., LAMBREGTS, P., LOFI, J., LUGLI, S., 
MANZI, V., MCGENITY, T.J., ROVERI, M., SIERRO, F.J. \& SUC J.-P.) (2008) Executive Summary. In: The Messinian Salinity crisis from mega-deposits to to microbiology - A consensus report (Ed. by F. Briand), CIESM Workshop Monographs, 33, 7-28.

CITA, M.B. \& COLOMBO, L. (1979) Sedimentation in the latest Messinian at Capo Rossello (Sicily). Sedimentology, 26, 497-522.

CITA, M.B. \& GARTNER, S. (1973) Studi sul Pliocene e uli strati di passaggio dal Miocene al Pliocene. IV. The stratotype Zanclean foraminiferal and nannofossil biostratigraphy. Riv. Ital. Paleont., 79, 4, 503-558.

CITA, M.B., RACCHETTI, S., BRAMBILLA, R., NEGRI, M., COLOMBAROLI, D., MORELLI, L., RITTER, M., ROVIRA, E., SALA, P., BERTARINI, L. \& SANVITO, S. (1999a) Changes in sedimentation rates in all Mediterranean drillsites document basin evolution and support starved basin conditions after early Zanclean flood. Mem. Soc. Geol. It., 54, 145-159.

CITA, M.B., RIO, D. \& SPROVIERI, R. (1999b) The Pliocene Series: Chronology of the type Mediterranean record and standard chronostratigraphy. In: The Pliocene: Time of Change (Ed. by J.H. Wrenn, J.-P. Suc \& S.A.G. Leroy), Amer. Ass. Stratigr. Palynologists Foundation, 4963.

CITA, M.B., SANTAMBROGIO, S., MELILLO, B. \& ROGATE, F. (1990) Messinian paleoenvironments: new evidence from the Tyrrhenian Sea (ODP Leg 107). In: Leg 107 (Ed. by K.A. Kastens, J. Mascle et al.), Init. Rep. Deep Sea Drill. Proj., Sci. Res., 107, 211-227.

CITA, M.B., WRIGHT, R.C., RYAN, W.B.F. \& LONGINELLI, A. (1978) Messinian paleoenvironments. In: Leg $42 A$ (Ed. by K. Hsü, L. Montadert et al.), Init. Rep. Deep Sea Drill. Proj., Sci. Res., 42, 1, 1003-1025.

CIVIS, J. (1977) Estudios de los Foraminiferos del afloramiento pliocenico de Can Albareda (Barcelona), analisis paleogeologico et biostratigrafico. Studia geol., 13, 105-126.

CLAUZON, G. (1973) The eustatic hypothesis and the Pre-Pliocene cutting of the Rhône Valley. In: Leg 13 (Ed. by W.B.F. Ryan \& K.J. Hsü), Init. Rep. Deep Sea Drill. Proj., 13, 2, 1251-1256.

CLAUZON, G. (1978) The Messinian Var canyon (Provence, Southern France) Paleogeographic implications. Mar. Geol., 27, 231-246.

CLAUZON, G. (1980a) Le canyon messinien de la Durance (Provence, France): une preuve paléogéographique du basin profond de dessiccation. Palaeogeogr., Palaeoclimatol., Palaeoecol., 29, 15-40.

CLAUZON, G. (1980b) Révision de l'interprétation géodynamique du passage miocènepliocène dans le bassin de Vera (Espagne méridionale) : les coupes d"Antas et de Cuevas del Almanzora. Riv. Ital. Paleont., 86, 1, 203-214.

CLAUZON, G. (1982) Le canyon messinien du Rhône: une preuve décisive du "desiccated deep-basin model" (Hsü, Cita et Ryan, 1973). Bull. Soc. géol. France, ser. 7, 24, 3, 597-610.

CLAUZON, G. (1990) Restitution de l'évolution géodynamique néogène du bassin du Roussillon et de l'unité adjacente des Corbières d'après les données écostratigraphiques et paléogéographiques. Paléobiol. Cont., 17, 125-155.

CLAUZON, G. (1996) Limites de séquence et évolution géodynamique. Géomorphologie, 1, 322.

CLAUZON, G. \& CRAVATTE, J. (1985) Révision chronostratigraphique de la série marine pliocène traversée par le sondage Canet (Pyrénées orientales): apports à la connaissance du Néogène du Roussillon. C. R. Acad. Sci. Paris, ser. 2, 301, 1351-1354.

CLAUZON, G., RUBINO, J.-L. \& CASERO, P. (1997) Regional modalities of the Messinian Salinity Crisis in the framework of two phases model. In: Neogene basins of the Mediterranean region: controls and correlation in space and time, R.C.M.N.S. Inter.-Coll., Catania, Program and Abstracts, 44-46.

CLAUZON, G., SUC, J.-P., AGUILAR, J.-P., AMBERT, P., CAPPETTA, H., CRAVATTE, J., DRIVALIARI, A., DOMÉNECH, R., DUBAR, M., LEROY, S., MARTINELL, J., MICHAUX, J., ROIRON, P., RUBINO, J.-L., SAVOYE, B. \& VERNET, J.-L. (1990) Pliocene geodynamic and climatic evolutions in the French Mediterranean region. Paleontologia i Evolucio, Spec. Vol. 2, 132-186.

CLAUZON, G., SUC, J.-P., GAUTIER, F., BERGER, A. \& LOUTRE, M.-F. (1996) Alternate interpretation of the Messinian salinity crisis: Controversy resolved? Geology, 24, 4, 363-366. 
CLAUZON, G., SUC, J.-P., POPESCU, S.-M., MARUNTTEANU, M., RUBINO, J.-L., MARINESCU, F. \& MELINTE, M.C. (2005) Influence of the Mediterranean sea-level changes over the Dacic Basin (Eastern Paratethys) in the Late Neogene. The Mediterranean Lago Mare facies deciphered. Bas. Res., 17, 437-462.

CLAUZON, G., SUC, J.-P., DUMURDŽANOV, N., MELINTE-DOBRINESCU, M.C. \& ZAGORCHEV, I. (2008) The Pliocene Gilbert-type fan delta of Draĉevo (Skopje area, Republic of Macedonia): Paleogeographic inference. Geol. Macedonica, 2, 21-28.

CLAUZON, G., SUC, J.-P., MELINTE-DOBRINESCU, M.C., JOUANNIC, G., JOLIVET, L., RUBINO, J.-L., POPESCU, S.-M., GORINI, C., BACHE, F. \& ESTRADA, F. (2009) New insights from the Andalusian Sorbas and Vera basins. Acta Naturalia de "L'Ateneo Parmense", 45, 1-4, 334-335.

COMAS, M.C., PLATT, J.P., SOTO, J.I. \& WATTS, A.B. (1999) The origin and tectonic history of the Alboran Basin: Insights from leg 161 results. In: Leg 161 (Ed. by R. Zhan, M.C. Comas \& A. Klaus), Proc. Ocean Drill. Progr., 161, 555-580.

CORNÉE, J.-J., FERRANDINI, M., SAINT MARTIN, J.P., MÜNCH, P., MOULLADE, M., RIBAUD-LAURENTI, A., ROGER, S., SAINT MARTIN, S. \& FERRANDINI, J. (2006) The late Messinian erosional surface and the subsequent reflooding in the Mediterranean: New insights from the Melilla-Nador basin (Morocco). Palaeogeogr., Palaeoclimatol., Palaeoecol., 230, 129-154.

COSENTINO, D., CIPOLLARI, P., FARANDA, C., FLORINDO, F., GENNARI, R., GLIOZZI, E., GROSSI, F., LAURENZI, M.A., LO MASTRO, S., SAMPALMIERO, G. \& SPROVIERI, M., 2009. Integrated analyses of the Maccarone section (northern Apennines, Italy). 13ème Congrès RCMNS Naples, Acta Naturalia de "L'Ateneo Parmense", 45, 1-4, 338-339.

CRAVATTE, J., DUFAURE, P., PRIM, M. \& ROUAIX, S. (1974) Les sondages du Golfe du Lion: Stratigraphie, Sédimentologie. Notes et Mémoires de la Compagnie Française des Pétroles, 11, 209-274.

CSATO, I., KENDALL, C.G.StC. \& MOORE, P.D. (2007) The Messinian problem in the Pannonian Basin, Eastern Hungary - Insights from stratigraphic simulations. Sedim. Geol., 201, 111-140.

DALLA, S., HARBY, H. \& SERAZZI, M. (1997) Hydrocarbon exploration in a complex incised valley fill: An example from the late Messinian Abu Madi Formation (Nile Delta Basin, Egypt). The Leading Edge, 16, 1819-1824.

DECIMA, A. \& WEZEL, F. (1971) Osservazioni sulle evaporiti messiniane della Sicilia centromeridionale. Riv. Min. Sicil., 130-132, 172-187.

DEMAREST, J.M. \& KRAFT, J.C. (1987) Stratigraphic record of Quaternary sea levels: Implications for more ancient strata. In: Sea-level fluctuation and coastal evolution (Ed. by D. Nummedal, O.H. Pilkey \& J.D. Howard), SEPM Special Publication., 41, 223-240.

DENIZOT, G. (1952) Le Pliocène dans la vallée du Rhône. Rev. Géogr. Lyon, 27, 327-357.

DOS REIS, A.T. (2001). La tectonique salifère et son influence sur l'architecture sédimentaire Quaternaire de la marge du Golfe du Lion - Méditerranée Occidentale. PhD Thesis, Université Pierre et Marie Curie - Paris 6.

DOS REIS, A.T., GORINI, C. \& MAUFFRET, A. (2005) Implications of Salt-sediment interactions for the Architecture of the Gulf of Lions deep-water sedimentary systems Western Mediterranean Sea. Mar. Petr. Geol. 22, 6-7, 713-746.

DOS REIS, A.T., GORINI, C., WEIBULL, W., PEROVANO, R., MEPEN, M. \& FERREIRA, E. (2008) Radial gravitacional gliding indicated by subsalt relief and salt-related structures: the example of the gulf of Lions, western Mediterranean. J. Geophy. 26, 3, 347-365.

DRAKE, N.A., EL-HAWAT, A.S. \& SALEM, M.J. (2008) The Development, Decline and Demise of the As Sahabi River System over the Last Seven Million Years. Garyounis Sci. Bull., spec. Issue, 5, 95-109.

DRIVALIARI, A., TICLEANU, N., MARINESCU, F., MARUNTTEANU, M. \& SUC, J.-P. (1999) A Pliocene climatic record at Ticleni (Southwestern Romania). In: The Pliocene: time of change (Ed. by J.H. Wrenn, J.-P. Suc \& S.A.G Leroy), Amer. Assoc. Stratigr. Palynol. Foundation, 103-108. 
EL EUCH - EL KOUNDI, N., FERRY, S., SUC, J.-P., CLAUZON, G., MELINTE-DOBRINESCU, M.C., SAFRA, A. \& ZARGOUNI, F. (2009) Messinian deposits and erosion in northern Tunisia. Inferences on the Sicily Strait during the Messinian Salinity Crisis. Terra Nova, 21, 41-48.

FAUQUETTE, S., SUC, J.-P., BERTINI, A., POPESCU, S.-M., WARNY, S., BACHIRI TAOUFIQ, N., PEREZ VILLA, M.-J., CHIKHI, H., SUBALLY, D., FEDDI, N., CLAUZON, G. \& FERRIER, J. (2006) How much did climate force the Messinian salinity crisis? Quantified climatic conditions from pollen records in the Mediterranean region. Palaeogeogr., Palaeoclimatol., Palaeoecol., 238, 281-301.

FORTUIN, A.R. \& KRIJGSMAN, W. (2003) The Messinian of the Nijar Basin (SE Spain): sedimentation, depositional environments and paleogeographic evolution. Sedim. Geol., 160, 213-242.

GAĈIĆ, M., POULAIN, P.-M., ZORE-ARMANDA, M. \& BARALE, V. (2002) Overview. In: Physical Oceanography of the Adriatic Sea. Past, Present, Future (Ed. by Cushman-Roisin, B., Gaĉić, M., Poulain, P.-M. \& Artegiani, A.), Kluwer Academic Publishers, 1-44.

GARCIA-CASTELLANOS, D., ESTRADA, F., JIMÉNEZ-MUNT, I., GORINI, C., FERNÀNDEZ, M., VERGÉS, J. \& DE VICENTE, R. (2009) Catastrophic flood of the Mediterranean after the Messinian salinity crisis. Nature, 462, 778-781.

GARCÍA-GARCÍA, F., CORBÍ, H., SORIA, J.M. \& VISERAS, C. (2011) Architecture analysis of a river flood-dominated delta during an overall sea-level rise (early Pliocene, SE Spain). Sedim. Geol., in press (doi: 10.1016/j.sedgeo.2011.02.010).

GAULLIER, V. (1993) Diapirisme salifère et dynamique sédimentaire dans le bassin LiguroProvençal. PhD Thesis, Université de Rennes.

GAUTIER, F., CLAUZON, G., SUC, J.-P., CRAVATTE, J. \& VIOLANTI, D. (1994) Age et durée de la crise de salinité messinienne. C. R. Acad. Sci. Paris, ser. 2, 318, 1103-1109.

GENNARI, R., IACCARINO, S.M., DI STEFANO, A., STURIALE, G., CIPOLLARI, P., MANZI, V., ROVERI, M. \& COSENTINO, D. (2008) The Messinian - Zanclean boundary in the Northern Apennine. Stratigraphy, 5, 3-4, 307-322.

GENNESSEAUX, M. \& LEFĖBVRE, D. (1980) Le Golfe du Lion et le Paléo-Rhône messinien. Géol. Médit., 7, 71-80.

GILBERT, G.K. (1885) The topographic features of lake shores. U.S. Geol. Survey Rep., 5, 75123.

GILBERT, G.K. (1890) Lake Bonneville. Monograph. U.S. Geol. Survey, 1, 1-438.

GILLET, H., LEROCILAIS, G. \& RÉHAULT, J.-P. (2007) Messinian event in the black sea: Evidence of a Messinian erosional surface. Mar. Geol., 244, 142-165.

GLOVER, C. \& ROBERTSON, A. (1998) Neotectonic intersection of the Aegean and Cyprus tectonic arcs: extensional and strike-slip faulting in the Isparta Angle, SW Turkey. Tectonophysics, 298, 103-132.

GORINI, C. (1993) Géodynamique d"une marge passive: le Golfe du Lion (Méditeranée Occidentale). PhD Thesis, Université Paul Sabatier, Toulouse.

GORINI, C., LE MARREC, A. \& MAUFFRET, A. (1993) Contribution to the structural and sedimentary history of the Gulf of Lions (Western Mediterranean) from the ECORS profiles, industrial seismic profiles and well data. Bull. Soc. géol. France, 164, 353-363.

GOUDIE, A.S. (2005) The drainage of Africa since the Cretaceous. Geomorphology, 67, 437456.

GOVERS, R. (2009) Choking the Mediterranean to dehydration: The Messinian salinity crisis. Geology, 37, 2, 167-170.

GRIFFIN, D.L. (2002) Aridity and humidity: two aspects of the late Miocene climate of North Africa and the Mediterranean. Palaeogeogr., Palaeoclimatol., Palaeoecol., 182, 65-91.

GUENNOC, P., GORINI, C. \& MAUFFRET, A. (2000) Histoire géologique du Golfe du Lion et cartographie du rift oligo-aquitanien et de la surface messinienne. Géol. France, 3, 67-97.

GUILLOCHEAU, F., DABARD, M.P., ROBIN, C. \& LOI, A. (2009) Les dépôts de tempêtes. Des domaines marins ouverts aux milieux restreints. Livre Association des Sédimentologues Français, 65, 102 p. 
HAXBY, W.F., MELKONIAN, A.K., COPLAN, J., CHAN, S.-M. \& RYAN, W.B.F. (2010) GeoMapApp freeware software, v.2.3. Lamont-Doherty Earth Observatory, Palisades, jgs.geoscienceworld.org/cgi/content/full/168/2/333.

HARDENBOL, J., THIERRY, J., FARLEY, M.B., JACQUIN, T., DE GRACIANSKY, P.-C. \& VAIL, P.R. (1997) Mesozoic-Cenozoic Sequence Chronostratigraphic Chart. In: Sequence Stratigraphy of European Basins (Ed. by P.-C. De Graciansky, J. Hardenbol, T. Jacquin, P.R. Vail \& M.B. Farley), SEPM Spec. Publ., 59.

HILGEN, F.J. \& LANGEREIS, C.G. (1989) Periodicities of $\mathrm{CaCO}_{3}$ cycles in the Pliocene of Sicily: discrepancies with the quasi-periods of the Earth"s orbital cycles? Terra Nova, 1, 409415.

HILGEN, F.J. \& LANGEREIS, C.G. (1993) A critical re-evaluation of the Miocene/Pliocene boundary as defined in the Mediterranean. Earth Planet. Sci. Lett., 118, 167-179.

HOMEWOOD, P., GUILLOCHEAU, F., ESCHARD, R. \& CROSS, T.A. (1992) Corrélations haute résolution et stratigraphie génétique: Une démarche intégrée. Bull. Centres Rech. Explor.-Prod. Elf-Aquitaine, 16, 357-381.

HSÜ, K.J., CITA, M.B. \& RYAN, W.B.F. (1973) The origin of the Mediterranean evaporites. In: Leg 13 (Ed. by W.B.F. Ryan, K.J. Hsü et al.), Init. Rep. Deep Sea Drill. Proj., 13, 1203-1231.

IACCARINO, S. \& BOSSIO, A. (1999) Paleoenvironment iof uppermost Messinian sequences in the Western Mediterranean (Sites 974, 975, and 978). In: Leg 161 (Ed. by R. Zahan, M.C. Comas \& A. Klaus), Proc. Ocean Drill. Progr., Sci. Results, 161, 529-541.

JOLIVET, L., AUGIER, R., ROBIN, C., SUC, J.-P. \& ROUCHY, J.M. (2006) Lithospheric-scale geodynamic context of the Messinian salinity crisis. Sedim. Geol., 188-189, 9-33.

KARISTINEOS, N.K. \& GEORGIADES-DIKEOULIA, E. (1985-86) The marine transgression in the Serres Basin. Ann. Géol. Pays Hellén., ser. 1, 33, 1, 221-232.

KRIJGSMAN, W. \& GARCÉS, M. (2004) Palaeomagnetic constraints on the geodynamic evolution of the Gibraltar Arc. Terra Nova, 16, 281-287.

KRIJGSMAN, W., HILGEN, F.J., MARABINI, S. \& VAI, G.B. (1999a) New paleomagnetic and cyclostratigraphic age constraints on the Messinian of the Northern Apennines (Vena del Gesso Basin, Italy). Mem. Soc. Geol. It., 54, 25-33.

KRIJGSMAN, W., HILGEN, F.J., RAFFI, J., SIERRO, F.J. \& WILSON, D.S. (1999b) Chronology, causes and progression of the Messinian salinity crisis. Nature, 400, 652-655.

KRIJGSMAN, W. \& MEIJER, P.TH. (2008) Depositional environments of the Mediterranean "Lower Evaporites" of the Messinian salinity crisis: constraints from quantitative analyses. Mar. Geol., 253, 73-81.

LASKAR, J., ROBUTEL, P., JOUTEL, F., GASTINEAU, M., CORREIA, A.C.M. \& LEVRARD, B., (2004) A long term numerical solution for the insolation quantities of the Earth. Astron. Astrophys., 428, 261-285.

LECKIE, D.A. (1994) Canterbury Plains, New Zealand-Implications for sequence stratigraphic models. Bull. Amer. Assoc. Petrol. Geol., 78, 1240-1256.

LEFĖBVRE, D. (1980) Evolution morphologique et structurale du Golfe du Lion. Essai de traitement statistique des données. PhD Thesis, Université Pierre et Marie Curie - Paris 6.

LI, X.S., BERGER, A., LOUTRE, M.-F., MASLIN, M.A., HAUG, G.H. \& TIEDEMANN, R. (1998) Simulating late Pliocene Northern Hemisphere climate with the LLN-2D model. Geophys. Res. Lett., 25, 915-918.

LOFI, J. (2002) La crise de salinité messinienne: conséquences directes et différées sur l"évolution sédimentaire de la marge du golfe du Lion. PhD Thesis, Université des Sciences et Techniques - Lille 1.

LOFI, J., RABINEAU, M., GORINI, C., BERNÉ S., CLAUZON, G., DE CLARENS, P., DOS REIS, T., MOUNTAIN, G.S., RYAN, W.B.F., STECKLER, M. \& FOUCHET, C. (2003) PlioQuaternary prograding clinoform wedges of the Western Gulf of Lions continental margin (NW Mediterranean) after the Messinian Salinity Crisis. Mar. Geol., 198, 289-317.

LOFI, J., GORINI, C., BERNÉ, S., CLAUZON, G., DOS REIS, A.T., RYAN, W.B.F. \& STECKLER, M.S. (2005) Erosional processes and paleo-environmental changes in the western gulf of Lions (SW France) during the Messinian salinity crisis. Mar. Geol., 217, 1-30. 
LOFI, J. \& BERNÉ, S. (2008) Evidences for Pre-Messinian submarine canyons incisions on the Gulf of Lions Miocene slope (Western Mediterranean). Mar. Petr. Geol., 25, 8, 804-817.

LOFI, J., SAGE, F., DÉVERCHÉRE, J., LONCKE, L., MAILLARD, A., GAULLIER, V., THINON, I., GILLET, H., GUENNOC, P. \& GORINI, C. (2011) Refining our knowledge of the Messinian Salinity Crisis records in the offshore domain through Multi-site seismic analysis. Bull. Soc. géol. France, 182, 2, 163-180.

LOGET, N., VAN DEN DRIESSCHE, J. \& DAVY, P. (2005) How did the Messinian Salinity Crisis end? Terra Nova, 17, 414-419.

LONDEIX, L., BENZAKOUR, M., DE VERNAL, A., TURON, J.-L. \& SUC, J.-P. (1999) Late Neogene dinoflagellate cyst assemblages from the Strait of Sicily, Central Mediterranean Sea: Paleoecological and biostratigraphical implications. In: The Pliocene: time of change (Ed. by J.H. Wrenn, J.-P. Suc \& S.A.G Leroy), Amer. Assoc. Stratigr. Palynol. Foundation, 65-91, Dallas.

LONDEIX, L., BENZAKOUR, M., SUC, J.-P. \& TURON, J.-L. (2007) Messinian palaeoenvironments and hydrology in Sicily (Italy): The dinoflagellate cyst record. Geobios, 40, 233-250.

LOURENS, L.J., HILGEN, F.J., LASKAR, J., SHACKLETON, N.J. \& WILSON, D. (2004) The Neogene Period. In: A Geological Time Scale (Ed. by F. Gradstein, J. Ogg \& A. Smith), pp. 409-440, Cambridge University Press.

LUGLI, S., MANZI, V. \& ROVERI, M. (2008) New facies interpretation of the Messinian evaporites in the Mediterranean. CIESM Workshop Monographs, 33, 67-72.

MAILLARD, A., GORINI, C., MAUFFRET, A., SAGE, F., LOFI, J. \& GAULLIER, V. (2006) Offshore evidence of polyphase erosion in the Valencia basin (Northwestern Mediterranean): Scenario for the Messinian Salinity Crisis. Sedim. Geol., 188-189, 69-91.

MANZI, V., LUGLI, S., ROVERI, M. \& SCHREIBER, C. (2009) A new facies model for the Upper Gypsum of Sicily (Italy): chronological and palaeoenvironmental constraints for the Messinian salinity crisis in the Mediterranean. Sedimentology, 56, 1937-1960.

MARY, C., IACCARINO, S., COURTILLOT, V., BESSE, J. \& AISSAOUI, D.M. (1993) Magnetostratigraphy of Pliocene sediments from the Stirone River (Po Valley). Geophys. Journ. Intern., 112, 359-380.

MATIAS I SENDRA, I. (1990) Els nannofossils calcaris del Plioce de la mediterrania nordoccidental. PhD Thesis, University of Barcelona.

MAUFFRET, A., AMMAR, A., GORINI, C. \& JABOUR, H. (2007) The Alboran Sea (Western Mediterranean) revisited with a view from the Moroccan Margin. Terra Nova, 19, 195-203.

MEIJER, P.Th. \& KRIJGSMAN, W. (2005) A quantitative analysis of the desiccation and refilling of the Mediterranean during the Messinian Salinity Crisis. Earth Planet. Sci. Lett., 240, 510-520.

MELINTE-DOBRINESCU, M.C., SUC, J.-P., CLAUZON, G., POPESCU, S.-M., ARMIJO, R., MEYER, B., BILTEKIN, D., ÇAĞATAY, M.N., UCARKUS, G., JOUANNIC, G., FAUQUETTE, S. \& ÇAKIR, Z. (2009) The Messinian Salinity Crisis in the Dardanelles region: Chronostratigraphic constraints. Palaeogeogr., Palaeoclimatol., Palaeoecol., 278, 24-39.

MILLER, K.G., KOMINZ, M.A., BROWNING, J.V., WRIGHT, J.D., MOUNTAIN, G.S., KATZ, M.E., SUGARMAN, P.J., CRAMER, B.S., CHRISTIE-BLICK, N. \& PEKAR, S.F. (2005) The Phaneorozoic Record of Global Sea-Level Change. Science, 310, 1293-1298.

MONTADERT, L., NICOLAIDES, S., SEMB, P.H. \& LIE, Ø. (2010) Petroleum systems offshore Cyprus. Amer. Assoc. Petrol. Geol. Bull., in press.

NEMEC, W., 1990. Aspects of sediment movement on steep delta slopes. Spec. Publs int. Ass. Sediment., 10, 29-73.

NÉRAUDEAU, D. (2007) Les bioaccumulations néogènes (calcaires à algues, faluns) d'Europe occidentale et leurs relations avec la crise messinienne. C. R. Palevol., 6, 59-71.

NÉRAUDEAU, D., GOUBERT, E., LACOUR, D. \& ROUCHY, J.M. (2001) Changing biodiversity of Mediterranean irregular echinoids from the Messinian to the Present-Day. Palaeogeogr., Palaeoclimatol., Palaeoecol., 175, 43-60. 
NESTEROFF, W. \& GLAÇON, G. (1977) Le caractère rythmique des evaporites messiniennes en Méditerranée orientale (coupe d'Eraclea Minoa, Sicile). Bull. Soc. géol. France, ser. 7, 19, 489-500.

NICOLAI, C. (2008) Tracing the As Sahabi Channel System in the Ajdabita Trough, Central Sirt Basin, Lybia. Garyounis Sci. Bull., spec. issue, 5, 85-94.

ODIN, G.S., RICCI LUCCHI, F., TATEO, F., COSCA, M. \& HUNZIKER, J.C. (1997) Integrated stratigraphy of the Maccarone section, Late Messinian (Marche region, Italy). In: Miocene Stratigraphy - An Integrated Approach (Ed. by A. Montanari, G.S. Odin and R. Coccioni), pp. 529-544, Elsevier, Amsterdam.

OTT D'ESTEVOU, P., MONTENAT, C. \& ALVADO, J.-C. (1990) Le basin de Vera - Garrucha. Doc. Trav. IGAL, 12-13, 165-187.

PAILLOU, P., SCHUSTER, M., TOOTH, S., FARR, T., ROSENQVIST, A., LOPEZ, S. \& MALEZIEUX, J.-M. (2009) Mapping of a major paleodrainage system in eastern Lybia using orbital imaging radar: The Kufrah River. Earth Planet. Sci. Lett., 277, 327-333.

PIERRE, C., CARUSO, A., BLANC-VALLERON, M.-M., ROUCHY J.M. \& ORSZAG-SPERBER, F. (2006) Reconstruction of the paleoenvironmental changes around the Miocene-Pliocene boundary along a West-East transect across the Mediterranean. Sedim. Geol., 188-189, 319340.

PIERRE, C. \& FONTES, J.-C. (1979) Oxygène 18, carbone 13, deutérium et soufre 34: marqueurs géochimiques de la diagenèse et du paléomilieu évaporitiques du Messinien de la Méditerranée. Bull. Mus. Nat. Hist. Nat. Paris, ser. 4, sect. C, 1, 3-18.

PIERRE, C., ROUCHY, J.-M. \& BLANC-VALLERON, M.-M. (1998) Sedimentological and stable isotope changes at the Messinian/Pliocene boundary in the Eastern Mediterranean (Holes 968A, 969A, and 969B). In: Leg 160 (Ed. by A.H.F. Robertson, K.-C. Emeis et al.), Proc. Ocean Drill. Progr., Sci. Results, 160, 3-8.

POISSON, A., ORSZAG-SPERBER, F., KOSUN, E., BASSETTI, M.A., MÜLLER, C., WERNLI, R. \& ROUCHY, J.M. (2011). The Late Cenozoic evolution of the Aksu basin (Isparta angle; SW Turkey). New insights. Bull. Soc. géol. France, 182, 2, 133-148.

POPESCU, S.-M. (2001) Repetitive changes in Early Pliocene vegetation revealed by highresolution pollen analysis: revised cyclostratigraphy of southwestern Romania. Rev. Palaeobot. Palynol., 120: 181-202.

POPESCU, S.-M. (2006) Late Miocene and early Pliocene environments in the southwestern Black Sea region from high-resolution palynology of DSDP Site 380A (Leg 42B). Palaeogeogr., Palaeoclimatol., Palaeoecol., 238, 64-77.

POPESCU, S.-M., BILTEKIN, D., WINTER, H., SUC, J.-P., MELINTE-DOBRINESCU, M.C., KLOTZ, S., COMBOURIEU-NEBOUT, N., RABINEAU, M., CLAUZON, G. \& DEACONU, F. (2010) Pliocene and Lower Pleistocene vegetation and climate changes at the European scale: Long pollen records and climatostratigraphy. Quat. Intern., 219, 152-167.

POPESCU, S.-M., DALESME, F., JOUANNIC, G., ESCARGUEL, G., HEAD, M.J., MELINTEDOBRINESCU, M.C., SÜTÖ-SZENTAI, M., BAKRAC, K., CLAUZON, G. \& SUC J.-P. (2009) Galeacysta etrusca complex, dinoflagellate cyst marker of Paratethyan influxes into the Mediterranean Sea before and after the peak of the Messinian Salinity Crisis. Palynology, 33, 2, 105-134.

POPESCU, S.-M., KRIJGSMAN, W., SUC, J.-P., CLAUZON, G., MARUNŢEANU, M. \& NICA, T. (2006b) Pollen record and integrated high-resolution chronology of the Early Pliocene Dacic Basin (Southwestern Romania). Palaeogeogr., Palaeoclimatol., Palaeoecol., 238, 1-4, 78-90.

POPESCU, S.-M., SUC, J.-P. \& LOUTRE, M.-F. (2006a) Early Pliocene vegetation changes forced by eccentricity-precession. Example from Southwestern Romania. Palaeogeogr., Palaeoclimatol., Palaeoecol., 238, 1-4, 340-348.

POPESCU, S.-M., SUC, J.-P., MELINTE, M., CLAUZON, G., QUILLÉVÉRÉ, F. \& SÜTÖSZENTAI, M. (2007) Earliest Zanclean age for the Colombacci and uppermost Di tetto formations of the "latest Messinian" northern Apennines: New palaeoenvironmental data from the Maccarone section (Marche Province, Italy). Geobios, 40, 3, 359-373. 
RABINEAU, M., BERNÉ, S., ASLANIAN, D., OLIVET, J.-L., JOSEPH, P., GUILLOCHEAU, F., BOURILLET, J.-L., LEDREZEN, E. \& GRANJEON, D (2005) Sedimentary sequences in the Gulf of Lions: a record of 1000,000 years climatic cycles: Mar. Pet. Geol., 22, 775-804.

RABINEAU, M., BERNÉ, S., OLIVET, J.-L., ASLANIAN, D., GUILLOCHEAU, F. \& JOSEPH, P. (2006) Paleo sea levels reconsidered from direct observation of paleoshoreline position during Glacial Maxima (for the last 500,000 yr): Earth Planet. Sci. Lett., 252, 119-137.

RAFFI, I., BACKMAN, J., FORNACIARI, E., PALIKE, H., RIO, D., LOURENS, L. \& HILGEN, F. (2006) A review of calcareous nannofossil astrobiochronology encompassing the past 25 million years. Quat. Sci. Rev., 25, 3113-3137.

ROUCHY, J.M. \& CARUSO, A. (2006) The Messinian salinity crisis in the Mediterranean basin: A reassessment of the data and an integrated scenario. Sedim. Geol., 188-189, 35-67.

ROUCHY, J.-M., ORSZAG-SPERBER, F., BLANC-VALLERON, M.-M., PIERRE, C., RIVIERE, M., COMBOURIEU-NEBOUT, N. \& PANAYIDES, I. (2001) Paleoenvironmental changes at the Messinian-Pliocene boundary in the Eastern Mediterranean (southern Cyprus basins): significance of the Messinian Lago-Mare. Sedim. Geol., 145, 93-117.

ROVERI, M., BASSETTI, M.A. \& RICCI LUCCHI, F. (2001) The Mediterranean Messinian salinity crisis: an Apennine foredeep perspective. Sedim. Geol., 140, 201-214.

ROVERI, M. \& MANZI, V. (2006) The Messinian salinity crisis: Looking for a new paradigm? Palaeogeogr., Palaeoclimatol., Palaeoecol., 238, 386-398.

ROVERI, M., MANZI, V., GENNARI, R., IACCARINO, S.M. \& LUGLI, S. (2008a) Recent advancements in the Messinian stratigraphy of Italy and their Mediterranean-scale implications. Boll. Soc. Paleontol. Ital., 47, 2, 71-85.

ROVERI, M., LUGLI, S., MANZI, V., \& SCHREIBER, C. (2008b) The Messinian Sicilian stratigraphy revisited: new insights for the Messinian salinity crisis. Terra Nova, 20, 483-488.

RYAN, W.B.F. (1978) Messinian badlands on the southeastern margin of the Mediterranean Sea. Mar. Geol., 27, 349-363.

RYAN, W.B.F. (2011) Geodynamics responses to a two-step model of the Messinian salinity crisis. Bull. Soc. géol. France, 182, 2, 73-78.

RYAN, W.B.F. \& CITA, M.B. (1978) The nature and distribution of Messinian erosional surface Indication of a several kilometer-deep Mediterranean in the Miocene. Mar. Geol., 27, 193-230.

SAID, R. (1982) The geological evolution of the River Nile in Egypt. Z. Geomorph., 26, 3, 305314.

SAVOYE, B. \& PIPER, D.J.W. (1991) The Messinian event on the margin of the Mediterranean Sea in the Nice arc, southern France. Mar. Geol., 97, 279-304.

SCHRADER, H.-J. (1978) Quaternary through Neogene history of the Black Sea, deduced from the paleoecology of diatoms, silicoflagellates, ebridians, and chrysomonads. In: Leg $42 B$ (Ed. by D.A. Ross, Y.P. Neprochnov et al. Init. Rep. Deep Sea Drill. Proj., 42, 2, 789-901.

SEMENENKO, V.N. (1995) Geological events at the Miocene/Pliocene boundary in the Eastern Paratethys. Geol. Soc. Greece, 4 (Spec. Publ.), 264-268.

SNEL, E., MARUNTTEANU, M., MACALET, R., MEULENKAMP, J.E. \& VAN VUGT, N. (2006) Late Miocene to Early Pliocene chronostratigraphic framework for the Dacic Basin, Romania. Palaeogeogr., Palaeoclimatol., Palaeoecol., 238, 1-4, 107-124.

SORIA, J.M., CARACUEL, J.E., CORBÍ, H., DINARĖS-TURELL, J., LANCIS, C., TENTMANCLÚS, J.E., VISERAS, C. \& YÉBENES, A. (2008) The Messinian-early Pliocene stratigraphic record in the southern Bajo Segura Basin (Betic Cordillera, Spain): Implications fort he Mediterranean salinity crisis. Sedim. Geol., 203, 267-288.

SPROVIERI, R., DI STEFANO, E., BONOMO, S., TAMBURINI, F. \& MCKENZIE, J. (2007) The Messinian - Pliocene boundary in the north Italy. Geophys. Res. Abstracts, 9, 06041.

STECKLER, M. S. \& WATTS, E. (1980) The Gulf of Lion: subsidence of a young continental margin. C. Nature, 287, 425-429.

SUC, J.-P. \& BESSAIS, E. (1990) Pérennité d"un climat thermo-xérique en Sicile, avant, pendant, après la crise de salinité messinienne. C. R. Acad. Sci. Paris, ser. 2, 310, 17011707.

SUC, J.-P., CLAUZON, G., ARMIJO, R., MEYER, B., MELINTE-DOBRINESCU, M.C., POPESCU, S.-M., LERICOLAIS, G., GILLET, H., ÇAĞATAY, M.N., JOUANNIC, G., BRUN, J.- 
P., SOKOUTIS, D., UCARKUS, G. \& ÇAKIR, Z. (2009) The Messinian Salinity Crisis in the Northeastern Aegean - Black Sea region. 13rd RCMNS Congress, Naples, Acta Naturalia de "L'Ateneo Parmense", 45, 1/4, 116-117.

SUC, J.-P., VIOLANTI, D., LONDEIX, L., POUMOT, C., ROBERT, C., CLAUZON, G., TURON, J.-L., FERRIER, J., CHIKHI, H., CAMBON, G. \& GAUTIER, F. (1995) Evolution of the Messinian Mediterranean environments: the Tripoli Formation at Capodarso (Sicily, Italy). Rev. Palaeobot. Palynol., 87, 51-79.

SUNAMURA, T. (1987) Coastal cliff erosion in Nii-Jima Island, Japan: present, past and future. In: International Geomorphology 1986 Part I. First International Conference on Geomorphology Proceedings, (Ed. By V. Gardiner), 1199-1212.

VAN COUVERING, J.A., CASTRADORI, D., CITA, M.B., HILGEN, F.J. \& RIO, D. (2000) The base of the Zanclean Stage and of the Pliocene Series. Episodes, 23, 3, 179-187.

VIOLANTI, D., DELA PIERRE, F., TRENKWALDER, S., LOZAR, F., CLARI, P., IRACE, A., D"ATRI, A. (2011) Biostratigraphic and palaeoenvironmental analyses of the Messinian/Zanclean boundary and Zanclean succession in the Moncucco quarry (Piedmont, Northwestern Italy). Bull. Soc. géol. France, 182, 2, 149-162.

WARNY, S., BART, P.J. \& SUC, J.-P. (2003) Timing and progression of climatic, tectonic and glacioeustatic influences on the Messinian Salinity Crisis. Palaeogeogr., Palaeoclimatol., Palaeoecol., 202, 59-66.

ZHENG, Z. \& CRAVATTE, J. (1986) Etude palynologique du Pliocène de la Côte d"Azur (France) et du littoral ligure (Italie). Geobios, 19, 6, 815-823.

\section{Tables}

Table 1. Key ages used in this paper, arranged from the oldest to the youngest, with information on their origin (events, proxies, localities, relevant references). Ages in bold characters are suggested in this paper. For ages corresponding to several events (5.96 and 5.6 Ma), the latter are indicated from the oldest (at the bottom) to the youngest (at the top). The relevant parts of this paper are indicated. 


\begin{tabular}{|c|c|c|c|c|c|}
\hline $\begin{array}{l}\text { Age } \\
\text { (Ma) }\end{array}$ & Events & Proxies & Localities & References & $\begin{array}{l}\text { Concerned parts } \\
\text { of this paper }\end{array}$ \\
\hline 5.31 & $\begin{array}{l}\text { Entrance of Mediterranean marine } \\
\text { waters into the Black Sea, Euxinian } \\
\text { Basin }\end{array}$ & $\begin{array}{l}\text { Ceratolithus acutus and Triquetrorhabdulus rugosus } \\
\text { (nannofossils) recorded at } 840.07 \text { m depth with } \\
\text { Mediterranean diatoms and dinoflagellate cysts, } \\
\text { age calibration by nannofossil biostratigraphy and } \\
\text { pollen cyclostratigraphy correlated with oxygen isotope } \\
\text { stratigraphy }\end{array}$ & $\begin{array}{l}\text { DSDP Site } 380 \text { (Black } \\
\text { Sea) }\end{array}$ & $\begin{array}{l}\text { Popescu et al., } 2010 \\
\text { Popescu, } 2006 \\
\text { Schrader, } 1978\end{array}$ & $\begin{array}{l}\text { Section III.3 } \\
\text { Fig. 20, } 22\end{array}$ \\
\hline 5.332 & - $\quad$ Base of Trubi, Zanclean GSSP & Bio- and magnetostratigraphy, astrochronology & Eraclea Minoa (Sicily) & $\begin{array}{l}\text { Lourens et al., } 2004 \\
\text { Van Couvering et al., } \\
2000 \\
\text { Hilgen \& Langereis, } \\
1993\end{array}$ & $\begin{array}{l}\text { Introduction } \\
\text { Section II.1 } \\
\text { Fig. } 9,11,22\end{array}$ \\
\hline 5.345 & - $\quad$ Lower Occurrence & Ceratolithus acutus (nannofossil) & Atlantic Ocean & Raffi et al., 2006 & $\begin{array}{l}\text { Introduction, } \\
\text { Sections II.2, II.3 } \\
\text { Fig. } 4,11,12\end{array}$ \\
\hline 5.36 & $\begin{array}{l}\text { Entrance of Mediterranean marine } \\
\text { waters into the Apennines foredeep } \\
\text { (AFC) }\end{array}$ & $\begin{array}{l}\text { First record of Mediterranean nannofossils, } \\
\text { foraminifers, dinoflagellate cysts, age calibration by } \\
\text { relationship between pollen record and eccentricity }\end{array}$ & $\begin{array}{l}\text { Maccarone (Apennines } \\
\text { foredeep) }\end{array}$ & $\begin{array}{l}\text { This paper } \\
\text { Popescu et al., } 2007\end{array}$ & $\begin{array}{l}\text { Sections II.2, III.3 } \\
\text { Figs. } 11,19,22\end{array}$ \\
\hline 5.45 & $\begin{array}{l}\text { - High sea-level water exchanges } \\
\text { between the Mediterranean and Dacic } \\
\text { Basin (DBC), Eastern Paratethys }\end{array}$ & $\begin{array}{l}\text { Evidence of Eastern Paratethyan dinoflagellate cysts } \\
\text { (Galeacysta etrusca, etc.) half a dark-light cycle above } \\
\text { the base of Arenazzolo }\end{array}$ & Eraclea Minoa (Sicily) & This paper & $\begin{array}{l}\text { Sections II.1, III.3 } \\
\text { Figs. } 10,17,22\end{array}$ \\
\hline 5.46 & $\begin{array}{l}\text { - End of Step I of reflooding followed by } \\
\text { instantaneous Step II }\end{array}$ & $\begin{array}{l}\text { Base of Arenazzolo ( } 6.5 \text { dark-light alternations below } \\
\text { the Zanclean GSSP, regarded as precession forced) }\end{array}$ & Eraclea Minoa (Sicily) & This paper & $\begin{array}{l}\text { Section III.3 } \\
\text { Figs. } 10,15,22\end{array}$ \\
\hline $\begin{array}{l}5.555 \pm \\
0.06\end{array}$ & - $\quad$ Ash layer & Radiometric age $\left({ }^{39} \mathrm{Ar} /{ }^{40} \mathrm{Ar}\right)$ & $\begin{array}{l}\text { Maccarone (Apennines } \\
\text { foredeep) }\end{array}$ & Cosentino et al., 2009 & $\begin{array}{l}\text { Section II.2 } \\
\text { Figs. } 11\end{array}$ \\
\hline 5.60 & $\begin{array}{ll} & \text { Halite in central basins } \\
\text { - } & \text { Second sea-level fall }(>1000 \mathrm{~m}) \\
\text { - } & \text { Closure of the Rifian corridor }\end{array}$ & $\begin{array}{l}\text { 16-17 precession cycles of Primary Lower Gypsum } \\
\text { Continuous dinoflagellate cyst and pollen records } \\
\text { (chronologically calibrated by bio-, } \\
\text { magnetostratigraphy and oxygen isotope stratigraphy) } \\
\text { indicating increased coastal conditions at the Atlantic } \\
\text { outlet of the Rifian corridor }\end{array}$ & $\begin{array}{l}\text { Apennines foredeep, } \\
\text { Sorbas } \\
\text { Salé (Atlantic Morocco) }\end{array}$ & $\begin{array}{l}\text { CIESM, } 2008 \\
\text { Krijgsman et al., } 1999 \mathrm{~b} \\
\text { Warny et al., } 2003\end{array}$ & $\begin{array}{l}\text { Section II.2 } \\
\text { Fig. } 1,22\end{array}$ \\
\hline 5.96 & $\begin{array}{ll}- & \text { Evaporites in marginal basins } \\
\text { - } & \text { Beginning of the MSC } \\
\text { - } & \text { First sea-level fall }(\sim 150 \mathrm{~m})\end{array}$ & $\begin{array}{l}\text { Bio- and magnetostratigraphy, astrochronology of the } \\
\text { first evaporites }\end{array}$ & Sorbas (SE Spain), Sicily & $\begin{array}{l}\text { Krijgsmann et al., } \\
1999 \mathrm{~b} \\
\text { Gautier et al., } 1994\end{array}$ & $\begin{array}{l}\text { Section II.1 } \\
\text { Fig. } 22\end{array}$ \\
\hline
\end{tabular}


Fig. 1. Map of the Messinian central basin evaporites and fluvial canyons identified around the Mediterranean Basin and adjacent territories during the peak of the MSC (5.60-5.56? Ma). At that time, the water level in the Mediterranean basin was some $1600 \mathrm{~m}$ lower than the global sea level. Major tectonic structures and corresponding topographic highs are drawn according to Jolivet et al. (2006) also valid for Figs. 16, 19, 20, 22, 23. Map of central basin evaporites is from Rouchy \& Caruso (2006). Map of fluvial canyons is from field observations of some of us (G.C., J.-P.S., J.-L.R., L.M.) and from the related literature (Nile area: Chumakov, 1967, 1973; Bentz \& Hughes, 1981; Said, 1982; Goudie, 2005; Lybia: Griffin, 2002; Drake et al., 2008; Nicolai, 2008 ; Paillou et al., 2009; North Tunisia: El Euch - El Koundi et al., 2009; Antalya Basin, South Turkey: Poisson et al., 2011; Southeastern Spain: Soria et al., 2008; Northwestern Italy: Breda et al., 2007). Map of the Po Basin and Apennine foredeep is from Boccaletti et al. (1990) and Clauzon et al. (1997), that of the Dacic Basin from Clauzon et al. (2005), that of the Pannonian Basin from Csato et al. (2007), and that of the Euxinian Basin to Gillet et al. (2007).

Fig. 2. Gilbert-type fan deltas (Gilbert, 1885, 1890) need a significant accommodation space. This was provided by erosion and very fast flooding in the case of the Mediterranean in early Zanclean time. A, Characteristic organization of Zanclean Gilbert-type fan deltas (Clauzon, 1990). They are composed of a prograding subaqueous part (clayey bottomset beds and conglomeratic to sandy foreset beds, the sedimentary dip of which may reach $30-35^{\circ}$ ) and an aggrading subaerial part (conglomeratic to sandy almost horizontal topset beds often affected by significant alteration). Two key chronological surfaces bound them: the Messinian Erosional Surface at the base (1), and the abandonment surface at the top (3). The diachronous subaqueous-continental (i.e. marine-continental in this case study) transition is sandwiched between the foreset beds and the topset beds (2), corresponding to a condensed layer (often a lignite). B, Carros Breccia (Nice, SE France) overlain by an iron crust (indicated by the arrow). C, Breccias of Salzidere (Bandirma, Turkey, southern coastline of the Marmara Sea) overlain by an iron-rich crust (indicated by the arrow). D, Coarse fluvial deposit with reworked blocks of Messinian gypsum within the Messinian fluvial canyon at Garrucha (Vera Basin, southeastern Spain). E, Coarse fluvial deposit with reworked blocks of Messinian gypsum within the Messinian fluvial canyon at San Ippolito (Volterra area, Central Italy).

Fig. 3. Location map of the studied areas with most of the main localities cited in the text and in Table 1. The map was created using GeoMapApp System developed by Haxby, W.F. et al. (2010). 1, Gulf of Lions (seismic profiles and boreholes), details are given in Figure 5; 2, Eraclea Minoa in the Caltanissetta Basin (onshore sections); 3, Maccarone (onshore section near Apiro); 4, Dardanelles Strait area (onshore sections).

Fig. 4. Chronostratigraphy and nannoplankton biostratigraphy of the Late Miocene and EarlyMiddle Pliocene. Ages of stages, polarity chrons refer to Lourens et al. (2004), NN zonation to Berggren et al. (1995) and Raffi et al. (2006), age of nannoplankton events to Raffi et al. (2006). The grey strips correspond to the generally accepted (CIESM, 2008) two steps of the MSC (Clauzon et al., 1996). See also Melinte-Dobrinescu et al. (2009) for more details concerning this nannoplankton chart.

Fig. 5. Line drawing and details of the seismic line perpendicular and parallel to the margin of the Gulf of Lions showing the major key surfaces related to the Messinian Salinity Crisis. Location of seismic profiles on Figure 6. See uninterpreted seismic profile on supplementary Figure 1. 
Fig. 6. Subsurface mapping of the basal Pliocene of the Gulf of Lions showing the limits between the various topographic zones (from the basin to the margin: halite, Planation surface "e", Messinian Erosional Surface) and location of line drawings shown in Figures 5 and 8. Boreholes: Ca, Calmar; Ci, Cicindelle; Si, Sirocco1; Mi, Mistral1; Tra, Tramontane1; Ra, Rascasse1; Au1, Autan1; CAg, Cap d"Agde1; Can, Canet1.

Fig. 7. Detail of the transition from the Messinian Erosional Surface (subaerial erosion "f") to the planation surface "e". The boundary between these two surfaces is located at a constant twoway travel time of 1.6 seconds over the entire margin $(a, b, c, d)$. Near the Pyrenees, the boundary is located at around a two-way travel time of 1.4 seconds $(e, f)$. This boundary represents the shoreline just before 5.46 Ma. Modified from Bache et al. (2009). See uninterpreted seismic profiles on supplementary Figure 2.

Fig. 8. Ligo 54 profile crossing the GLP2 borehole. The erosional nature of the planation surface "e" and the transgressive nature of sediments deposited above it are outlined by arrows. The 50 $\mathrm{m}$ of azoic sand described in GLP2 borehole could correspond to the transgressive sands eroded from upstream by the wave erosion (planation surface "e"). Location of seismic profiles on Figure 6. See uninterpreted seismic profile on supplementary Figure 3.

Fig. 9. Eraclea Minoa (southern Sicily). Simplified classical stratigraphic succession of the Tortonian to Zanclean Sicilian series (Decima \& Wezel, 1971). Location of Eraclea Minoa and Capo Rossello in Sicily. Location map of the two studied sections at Eraclea Minoa. View of the eastern part of the Eraclea Minoa succession with location of Sections 1 and 2, and of the Zanclean Stage GSSP. Eraclea Minoa sections 1 and 2 compared: the grey surface shows the missing part (eroded) of Lago Mare in Section 2. Nannoplankton data according to A. Di Stefano (personal communication) and our own results. View of Section 1. The white box corresponds to the girdled stratigraphic interval in Fig. 9A. View of Section 2.

Fig. 10. Environmental significance of Lago Mare vs. Arenazzolo and vs. Trubi in Sicily. Age of Arenazzolo. A, View of the dark-light bands at Eraclea Minoa (Section 1) as reported on Figs. 8D and 9B. B, Upper part of Section 1 of Eraclea Minoa. Studied samples: 1 to 44 from Eraclea Minoa (Section 1), a to d from Capo Rossello. Same legend as in Figure 8. C, Total $\mathrm{CaCO}_{3}$ content from the Arenazzolo Unit at Section 1 of Eraclea Minoa. D, Pollen ratio "Pinus / Halophytes" (logarithmic abscissa scale). E,Dinoflagellate cyst assemblages with respect to their environmental (coastal to oceanic) significance. Distribution of Paratethyan dinoflagellate cysts is indicated.

Fig. 11. Maccarone (Apiro, Marche). A, Litho-, bio- and chronostratigraphy. Ages of paleomagnetic Chron C3n.4n and of the base of Zanclean are from Lourens et al. (2004), age of the Lowest Occurrence of Ceratolithus acutus is from Raffi et al. (2006). Age (5.36 Ma) in bold characters is the estimated age of the entrance of marine waters into the Apennine foredeep. Lithology from Popescu et al. (2007). Magnetostratigraphy: Messinian sediments (G. Napoleone, personal communication), Zanclean sediments (Gennari et al., 2008). B, Pollen ratio "Subtropical Elements (SE) / Altitudinal Elements (AE)" (logarithmic abscissa scale), plotted on the log of the Maccarone section. C, Eccentricity curve between 5.62 and $5.30 \mathrm{Ma}$ (Laskar et al., 2004), plotted on the orbital timescale.Uncertainty on the age of the ash is indicated by the grey range.

Fig. 12. Two types of Messinian - Zanclean deposit organization in the area of the Dardanelles Strait. A, Location map. 1, Intepe; 2, Seddülbahir. The dotted grey line displays the local coastline at the end of reflooding of the Mediterranean after the MSC. B, Intepe, a bay-lagoon locality, and Seddülbahir where a Gilbert-type fan delta infils a ria resulting from a Messinian fluvial canyon, with location of photographs C to E. C, Middle part of the Intepe section showing the lignite overlain by rubefied (fired) clays. D, Seddülbahir: clayey bottomset beds of the Gilbert-type fan delta. E, Sandy foreset beds of the Gilbert-type fan delta northward Intepe. 
Fig. 13. A, B, Examples of transgressive surfaces in southeastern France. These erosional surfaces, related to Miocene transgressions (Champion et al., 2000), present a smooth morphology over large distance, which may be compared with the planation surface "e" highlighted in this study. On picture B, Cretaceous limestone deposits are truncated and overlain by Miocene transgressive deposits. Nerthe Massif, Provence. Photograph: Jean-Loup Rubino. C, D, Examples of present shore in the North of France where the combined effect of waves and tides leads to erosion of the cliff. These shorelines are representative analogues of our interpretation of the landscape in the Gulf of Lions just before the Step II of reflooding. C, Vattetot-sur-Mer, Seine Maritime. Photograph: Charlélie Coutinho. D, Etretat, Seine-Maritime. Photograph: Anne Duperret.

Fig. 14. Two present-day topographic profiles (A-B, C-D) illustrating the physiography of the Mediterranean Basin and some peripherial areas just after the Messinian Salinity Crisis. Sills and nearby mountains are indicated. On the profiles, vertical dotted lines indicate direction changes. The map was created using GeoMapApp System developed by Haxby et al., 2010).

Fig. 15. Paleogeographic map of the Mediterranean Basin and Eastern Paratethys at the end of Step I of the Mediterranean reflooding, i.e. just before the dramatic rise in sea level at 5.46 Ma. At that time, the water level in the Mediterranean Basin was some $650 \mathrm{~m}$ below the Atlantic Ocean, the waters of which flowed into the Mediterranean.

Fig. 16. Paleogeographic map of the Mediterranean Basin and Eastern Paratethys just after Step II of the Mediterranean reflooding, i.e. just after the dramatic rise in sea level at 5.46 Ma. At that time, the Mediterranean and the Atlantic were connected (i.e. at the same sea level). The Block Formations, now frequently identified (according to literature or our own observations) at the base of the Zanclean marine sediments, are indicated by red circles. Localities with gypsum or anhydrite blocks: Los Feos (1) in the Nijar Basin and Garrucha (2) in the Vera Basin (Clauzon, 1980b) (SE Spain); San Ippolito (3) near Volterra (Central Italy), Kalamaki (4) on the island of Zakynthos; Loutra Eleftheron (5) near Kavala (NE Greece); Gebiz (6) near Antalya (S Turkey) (Glover and Robertson, 1998); Amargeti (7), Pissouri (8) Psematismenos (9) and Boghaz (10) on the island of Cyprus; Mağaracik (11) near Samandağ (SE Turkey); Kferyeho (12) near Lattaquié (Syria). Localities with various rocks: Oued Haddouba and Ikamba (13) in the Melilla area (N Morocco) (Cornée et al., 2006); La Pedrera (14) near San Miguel de Salinas (E Spain) (García-García et al., 2011); Le Boulou (15) and Ille sur Têt (16) near Perpignan (S France); Cessenon (17) and Magalas (18) near Béziers (Ambert et al., 1998) and Tour de Piquet and Bruque-Cabal (19) near Montpellier (Ambert, 2011) (SE France); Carros (20) in the Nice area (SE France) (Clauzon, 1978); Ventimiglia (21) (NW Italy) (Breda et al., 2007); Salzidere (22) in the Bandirma region (S Marmara Sea, N Turkey).

Fig. 17. Paleogeographic map of the Mediterranean Basin and Eastern Paratethys at $5.45 \mathrm{Ma}$ (after the second step of the Mediterranean reflooding) when the Mediterranean Sea and Dacic Basin re-connected due to continuing rise of global sea level.

Fig. 18. Zanclean Gilbert-type fan deltas in the Balkans. A, Serres (Ano Metochi): foreset beds of the Zanclean Gilbert-type fan delta nested within the Miocene piedmont alluvial fan; B \& C, Zanclean Gilbert-type fan delta near Skopje: B, foreset beds at Draĉevo; C, bottomset beds at Batinci; D, Niš: bottomset beds of the Zanclean Gilbert-type fan delta at Gabrovackka Reka.

Fig. 19. Paleogeographic map of the Mediterranean basin and Eastern Paratethys at $5.36 \mathrm{Ma}$ when the Mediterranean Sea and Apennine foredeep reconnected due to continuing rise of global sea level. 
Fig. 20. Paleogeographic map of the Mediterranean basin and Eastern Paratethys at $5.31 \mathrm{Ma}$ when the Dacic and Euxinian basins connected (Popescu et al., 2010) due to continuing rise of global sea level.

Fig. 21. Estimate of the initial position of the paleoshoreline and of the planation surface "e" at the beginning of the Pliocene. The Pliocene and Quaternary total subsidence is deduced from Rabineau et al. (2006).

Fig. 22. Variation of the Mediterranean sea level in the Gulf of Lions between 6 and $5.30 \mathrm{Ma}$ encompassing the Messinian Salinity Crisis, with special attention to the reflooding phase.

Successive major changes are estimated with respect to present-day sea level (noted "0"). A two-step process is highlighted: - the First Step (? - $5.46 \mathrm{Ma}$ ) is characterized by a relative sealevel rise $(500 \mathrm{~m}$ at the most). A first transgression flattened previous topography to build a remarkable ravinement surface (slope value between 0 and 1\%); - the Second Step (at 5.46 $\mathrm{Ma}$ ) corresponds to an ultra-rapid Mediterranean sea-level rise contained between 600 and 900 $\mathrm{m}$ in amplitude. Just after this outstanding and sudden rise in sea-level, Arenazzolo deposition began. After Gilbert-type fan delta sediments began to infill the rias, successive connections of the Mediterranean Basin with adjacent basins formed as global sea level continued to rise: with the Dacic Basin (Eastern Paratethys) at $5.45 \mathrm{Ma}$, with the Apennine foredeep at $5.36 \mathrm{Ma}$, at last with the Euxinian Basin (Eastern Paratethys) at 5.31 Ma (see Figures 17 to 20). 


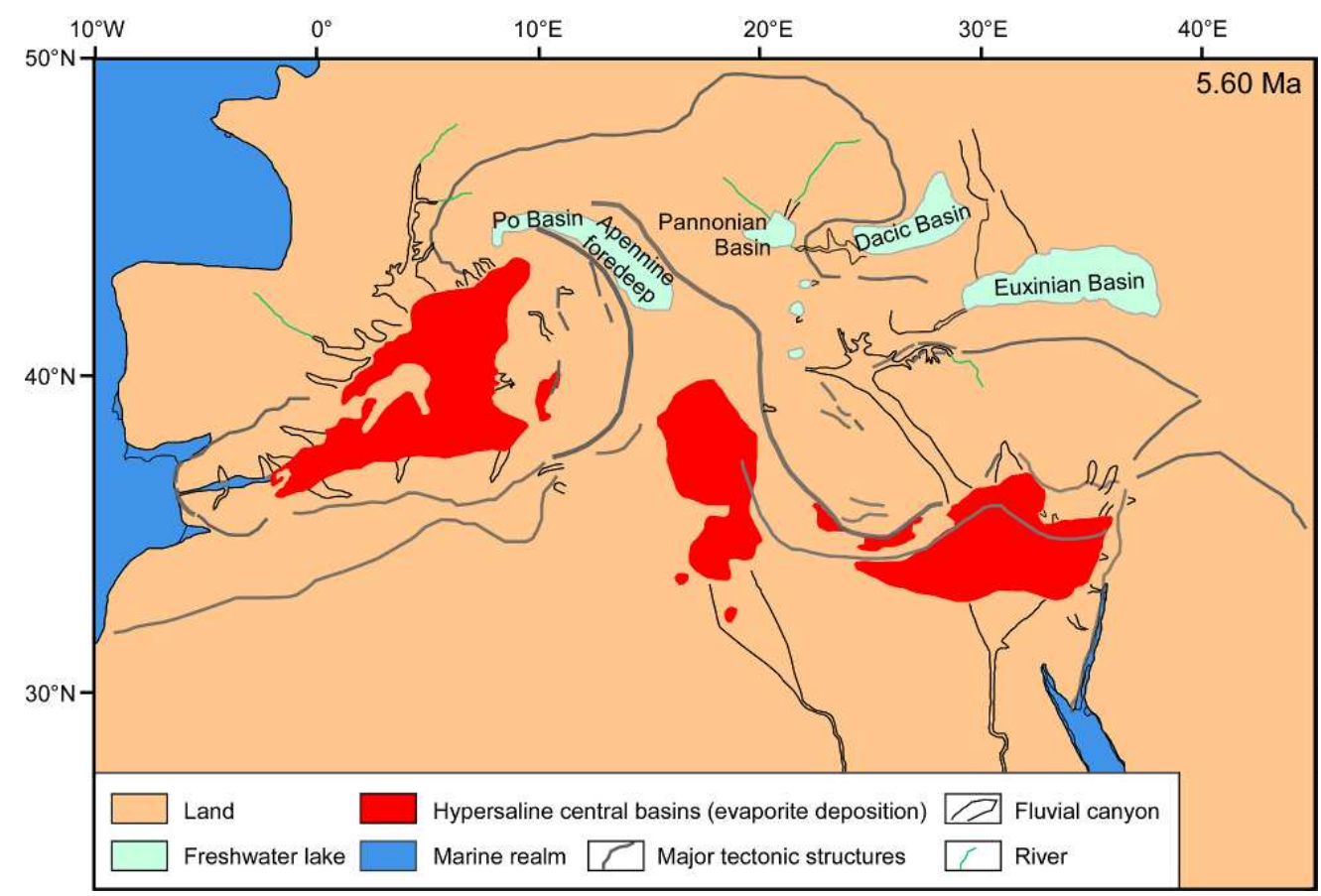

Map of the Messinian central basin evaporites and fluvial canyons identified around the Mediterranean Basin and adjacent territories during the peak of the MSC (5.60-5.56? Ma). At that time, the water level in the Mediterranean basin was some $1600 \mathrm{~m}$ lower than the global sea level. Major tectonic structures and corresponding topographic highs are drawn according to Jolivet et al. (2006) also valid for Figs. 16, 19, 20, 22, 23. Map of central basin evaporites is from Rouchy \& Caruso (2006). Map of fluvial canyons is from field observations of some of us (G.C., J.-P.S., J.-L.R., L.M.) and from the related literature (Nile area: Chumakov, 1967, 1973; Bentz \& Hughes, 1981; Said, 1982; Goudie, 2005; Lybia: Griffin, 2002; Drake et al., 2008; Nicolai, 2008 ; Paillou et al., 2009; North Tunisia: El Euch - El Koundi et al., 2009; Antalya Basin, South Turkey: Poisson et al., 2011; Southeastern Spain : Soria et al., 2008; Northwestern Italy: Breda et al., 2007). Map of the Po Basin and Apennine foredeep is from Boccaletti et al. (1990) and Clauzon et al. (1997), that of the Dacic Basin from Clauzon et al. (2005), that of the Pannonian Basin from Csato et al. (2007), and that of the Euxinian Basin to Gillet et al. (2007). 
Gilbert-type fan deltas (Gilbert, 1885, 1890) need a significant accommodation space. This was provided by erosion and very fast flooding in the case of the Mediterranean in early Zanclean time.

A, Characteristic organization of Zanclean Gilbert-type fan deltas (Clauzon, 1990). They are composed of a prograding subaqueous part (clayey bottomset beds and conglomeratic to sandy foreset beds, the sedimentary dip of which may reach $30-35^{\circ}$ ) and an aggrading subaerial part (conglomeratic to sandy almost horizontal topset beds often affected by significant alteration). Two key chronological surfaces bound them: the Messinian Erosional Surface at the base (1), and the abandonment surface at the top (3). The diachronous subaqueous-continental (i.e. marinecontinental in this case study) transition is sandwiched between the foreset beds and the topset beds (2), corresponding to a condensed layer (often a lignite).

B, Carros Breccia (Nice, SE France) overlain by an iron crust (indicated by the arrow). C, Breccias of Salzidere (Bandirma, Turkey, southern coastline of the Marmara Sea) overlain by an iron-rich crust (indicated by the arrow). 
D, Coarse fluvial deposit with reworked blocks of Messinian gypsum within the Messinian fluvial canyon at Garrucha (Vera Basin, southeastern Spain).

E, Coarse fluvial deposit with reworked blocks of Messinian gypsum within the Messinian fluvial canyon at San Ippolito (Volterra area, Central Italy).

$166 \times 229 \mathrm{~mm}(150 \times 150 \mathrm{DPI})$ 
Location map of the studied areas with most of the main localities cited in the text and in Table 1. The map was created using GeoMapApp System developed by Haxby, W.F. et al. (2010).

1, Gulf of Lions (seismic profiles and boreholes), details are given in Figure 5; 2, Eraclea Minoa in the Caltanissetta Basin (onshore sections); 3, Maccarone (onshore section near Apiro); 4, Dardanelles Strait area (onshore sections). 


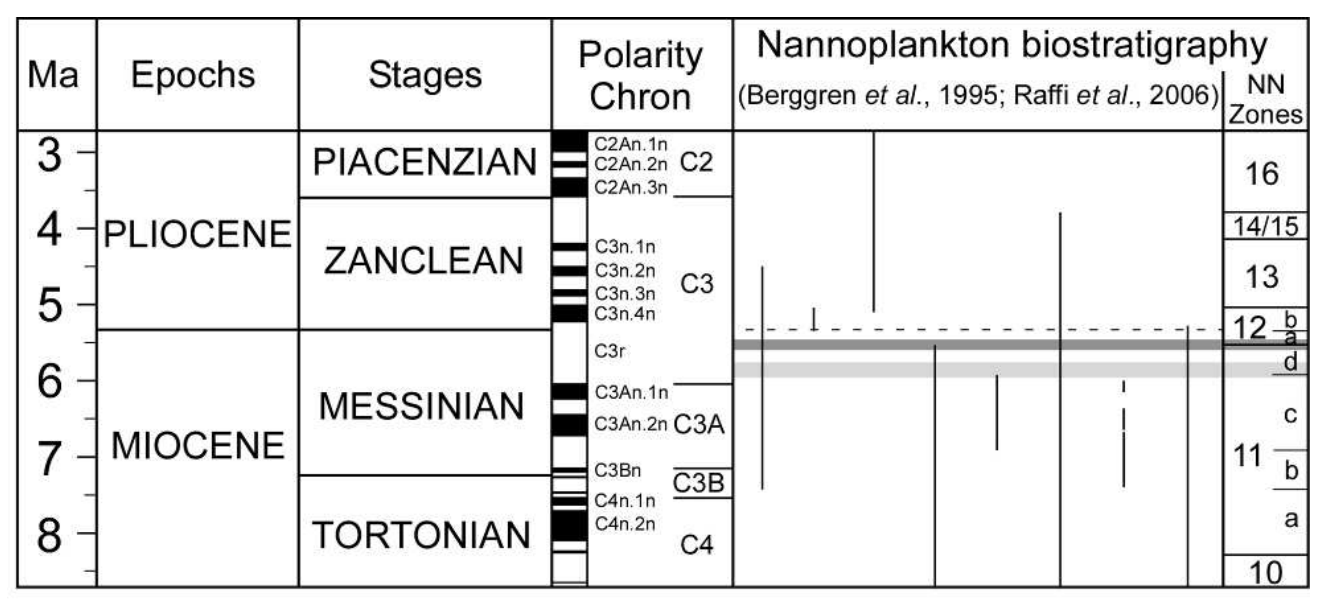

Chronostratigraphy and nannoplankton biostratigraphy of the Late Miocene and Early-Middle Pliocene. Ages of stages, polarity chrons refer to Lourens et al. (2004), NN zonation to Berggren et al. (1995) and Raffi et al. (2006), age of nannoplankton events to Raffi et al. (2006). The grey strips correspond to the generally accepted (CIESM, 2008) two steps of the MSC (Clauzon et al., 1996). See also Melinte-Dobrinescu et al. (2009) for more details concerning this nannoplankton chart. 

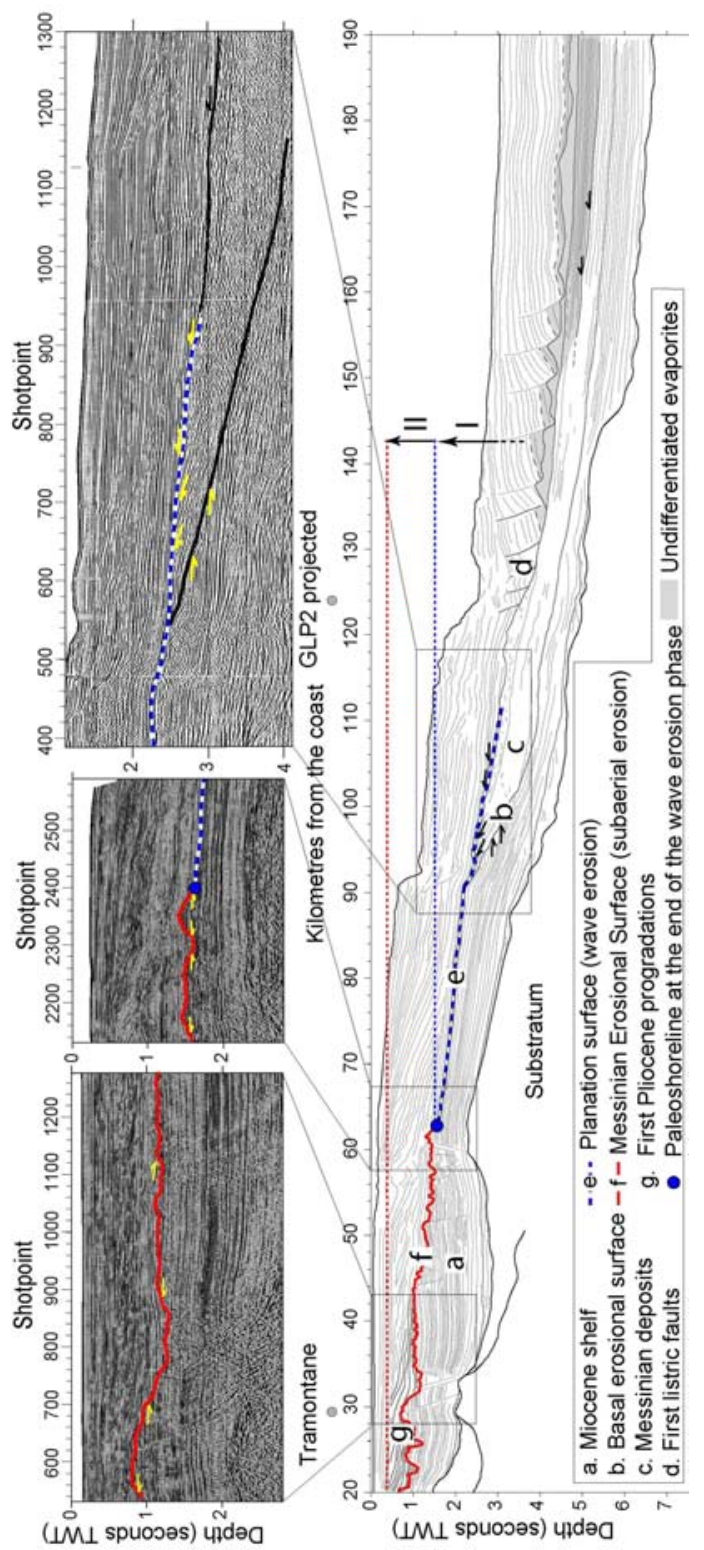

Line drawing and details of the seismic line perpendicular and parallel to the margin of the Gulf of Lions showing the major key surfaces related to the Messinian Salinity Crisis. Location of seismic profiles on Figure 6. See uninterpreted seismic profile on supplementary Figure 1. $118 \times 262 \mathrm{~mm}(300 \times 300 \mathrm{DPI})$ 


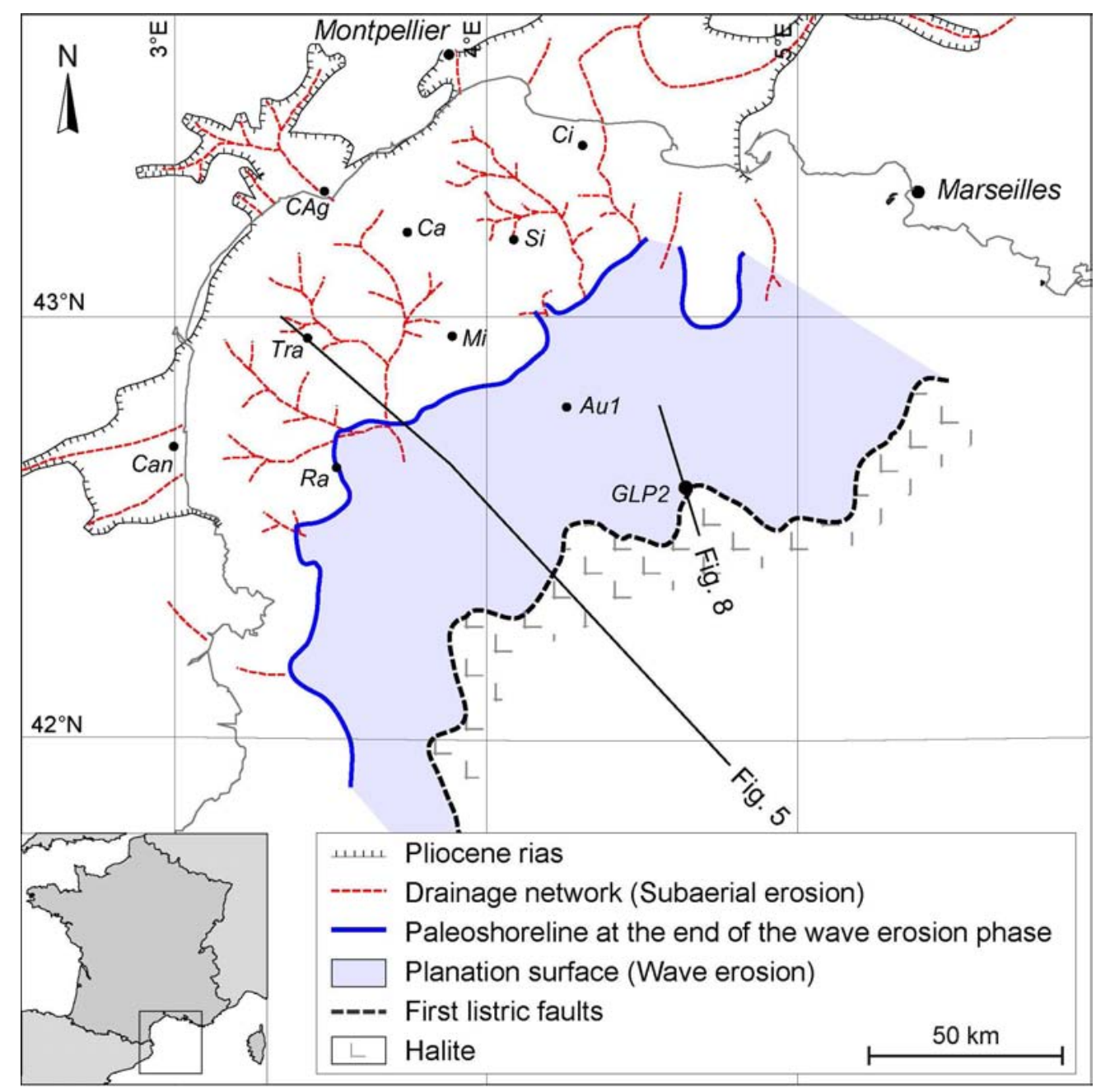

Subsurface mapping of the basal Pliocene of the Gulf of Lions showing the limits between the various topographic zones (from the basin to the margin: halite, Planation surface " $e$ ", Messinian Erosional Surface) and location of line drawings shown in Figures 5 and 8.

Boreholes: Ca, Calmar; Ci, Cicindelle; Si, Sirocco1; Mi, Mistral1; Tra, Tramontane1; Ra, Rascasse1; Au1, Autan1; CAg, Cap d'Agde1; Can, Canet1. 


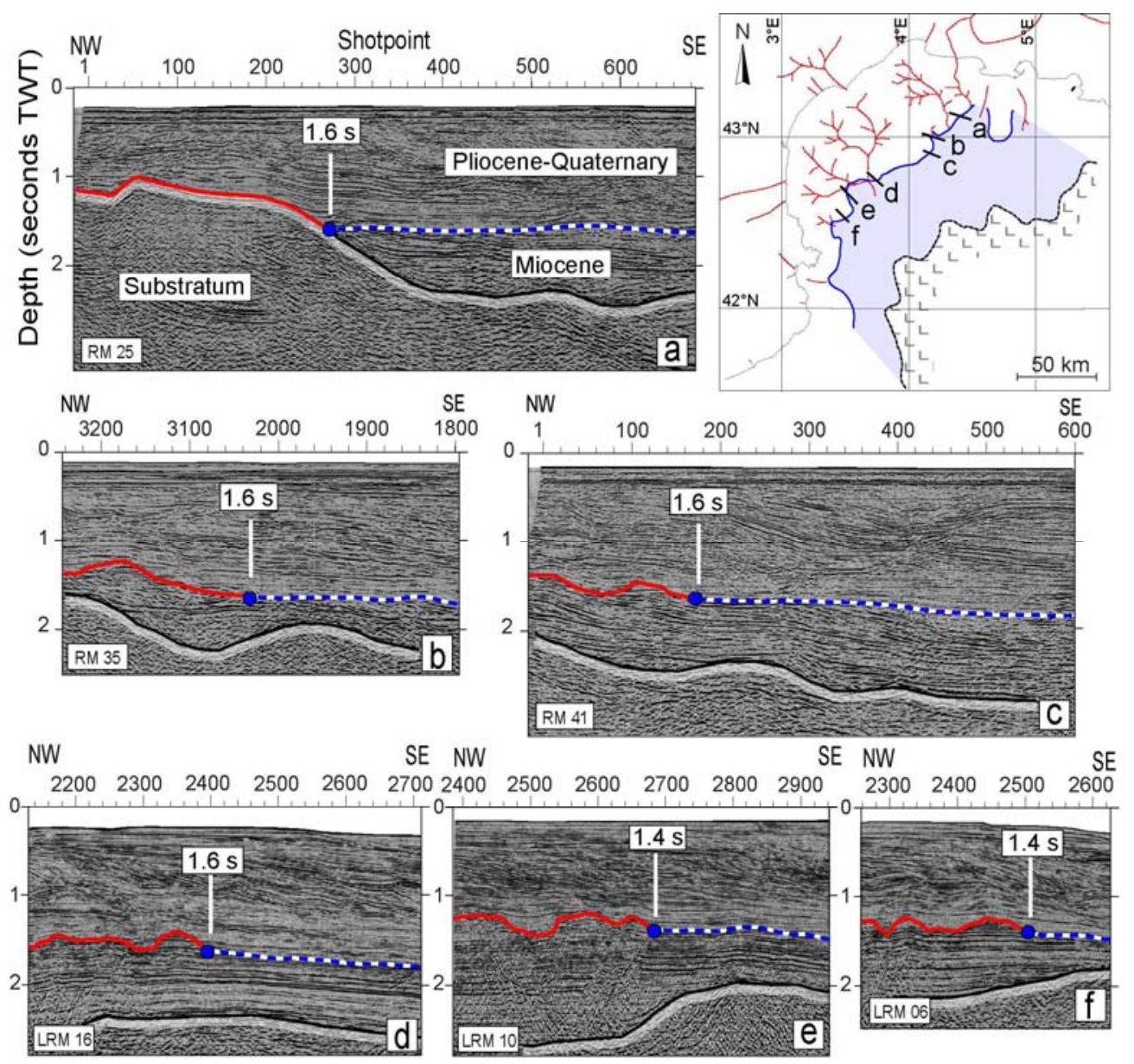

Detail of the transition from the Messinian Erosional Surface (subaerial erosion " $f$ ") to the planation surface " $e$ ". The boundary between these two surfaces is located at a constant two-way travel time of 1.6 seconds over the entire margin $(a, b, c, d)$. Near the Pyrenees, the boundary is located at around a two-way travel time of 1.4 seconds $(e, f)$. This boundary represents the shoreline just before 5.46 Ma. Modified from Bache et al. (2009). See uninterpreted seismic profiles on supplementary Figure 2. $168 \times 158 \mathrm{~mm}(300 \times 300 \mathrm{DPI})$ 


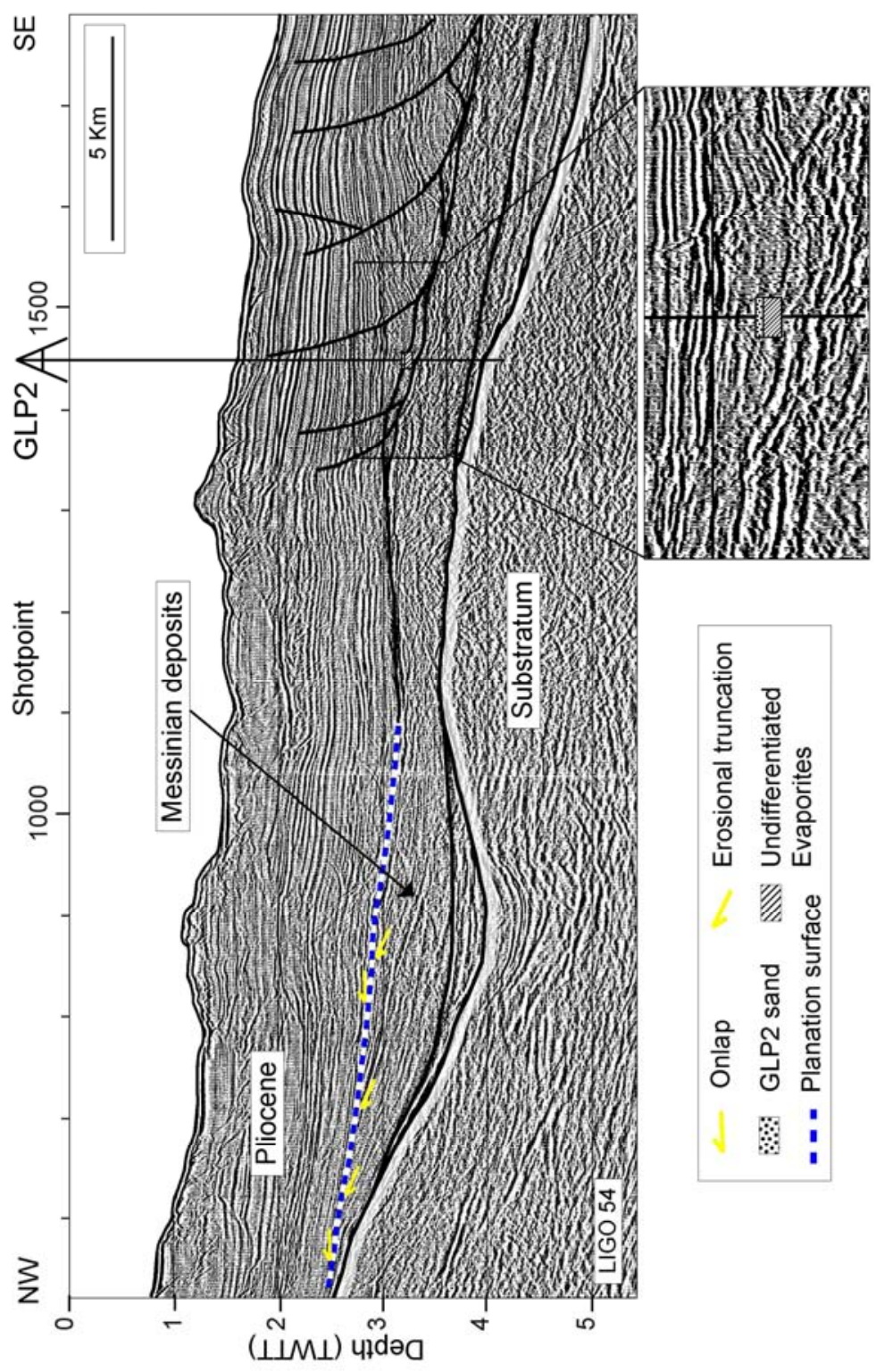

Ligo 54 profile crossing the GLP2 borehole. The erosional nature of the planation surface "e" and the transgressive nature of sediments deposited above it are outlined by arrows. The $50 \mathrm{~m}$ of azoic sand described in GLP2 borehole could correspond to the transgressive sands eroded from upstream by the wave erosion (planation surface "e"). Location of seismic profiles on Figure 6 . See uninterpreted seismic profile on supplementary Figure 3. $168 \times 262 \mathrm{~mm}(300 \times 300 \mathrm{DPI})$ 


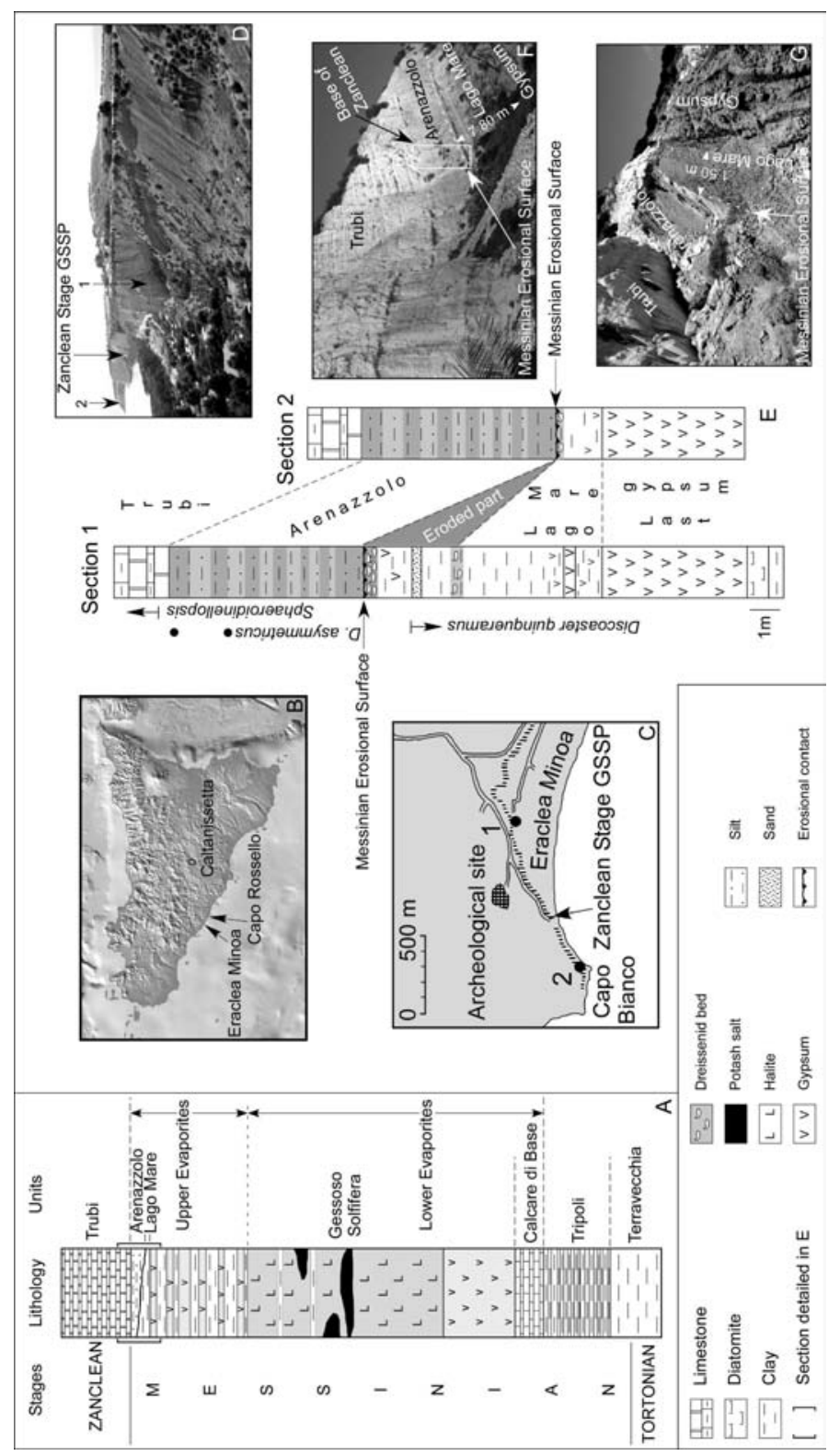

Eraclea Minoa (southern Sicily).
A. Simplified classical stratigraphic succession of the Tortonian to Zanclean Sicilian series (Decima \& Wezel, 1971).

B. Location of Eraclea Minoa and Capo Rossello in Sicily.

\section{Location map of the two studied sections at Eraclea Minoa.}

D. View of the eastern part of the Eraclea Minoa succession with location of Sections 1 and 2, and of the Zanclean Stage GSSP.

E. Eraclea Minoa sections 1 and 2 compared: the grey surface shows the missing part (eroded) of Lago Mare in Section 2. Nannoplankton data according to A. Di Stefano (personal communication) and our own results.

F. View of Section 1. The white box corresponds to the girdled stratigraphic interval in Fig. 9A. G. View of Section 2. 

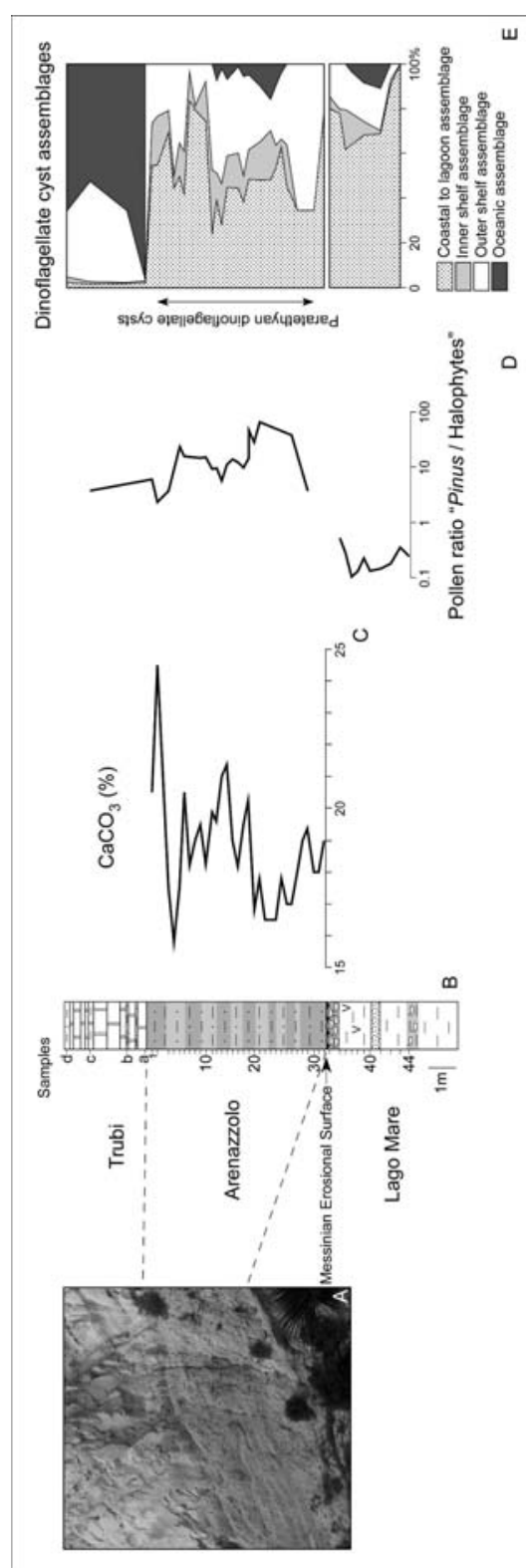

. Environmental significance of Lago Mare vs. Arenazzolo and vs. Trubi in Sicily. Age of Arenazzolo.

A, View of the dark-light bands at Eraclea Minoa (Section 1) as reported on Figs. 8D and 9B. B, Upper part of Section 1 of Eraclea Minoa.

Studied samples: 1 to 44 from Eraclea Minoa (Section 1), a to d from Capo Rossello. Same legend as in Figure 8.

C, Total $\mathrm{CaCO} 3$ content from the Arenazzolo Unit at Section 1 of Eraclea Minoa. D, Pollen ratio "Pinus / Halophytes" (logarithmic abscissa scale).

E, Dinoflagellate cyst assemblages with respect to their environmental (coastal to oceanic) significance. Distribution of Paratethyan dinoflagellate cysts is indicated.

$$
87 \times 262 \mathrm{~mm}(300 \times 300 \text { DPI })
$$




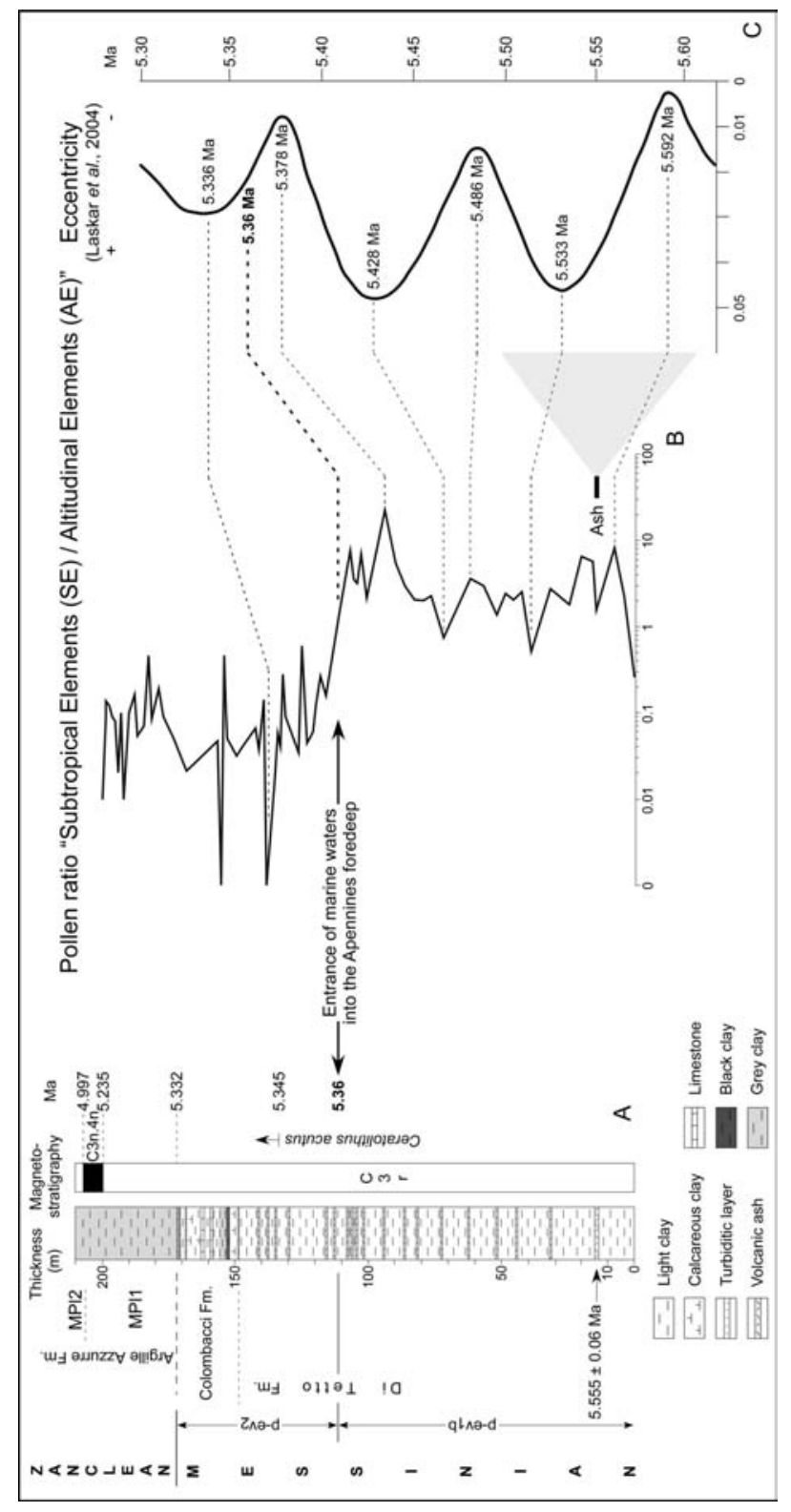

Maccarone (Apiro, Marche).

A, Litho-, bio- and chronostratigraphy. Ages of paleomagnetic Chron C3n.4n and of the base of Zanclean are from Lourens et al. (2004), age of the Lowest Occurrence of Ceratolithus acutus is from Raffi et al. (2006). Age (5.36 Ma) in bold characters is the estimated age of the entrance of marine waters into the Apennine foredeep.

Lithology from Popescu et al. (2007). Magnetostratigraphy: Messinian sediments (G. Napoleone, personal communication), Zanclean sediments (Gennari et al., 2008).

B, Pollen ratio "Subtropical Elements (SE) / Altitudinal Elements (AE)" (logarithmic abscissa scale), plotted on the log of the Maccarone section.

C, Eccentricity curve between 5.62 and 5.30 Ma (Laskar et al., 2004), plotted on the orbital timescale.Uncertainty on the age of the ash is indicated by the grey range. 


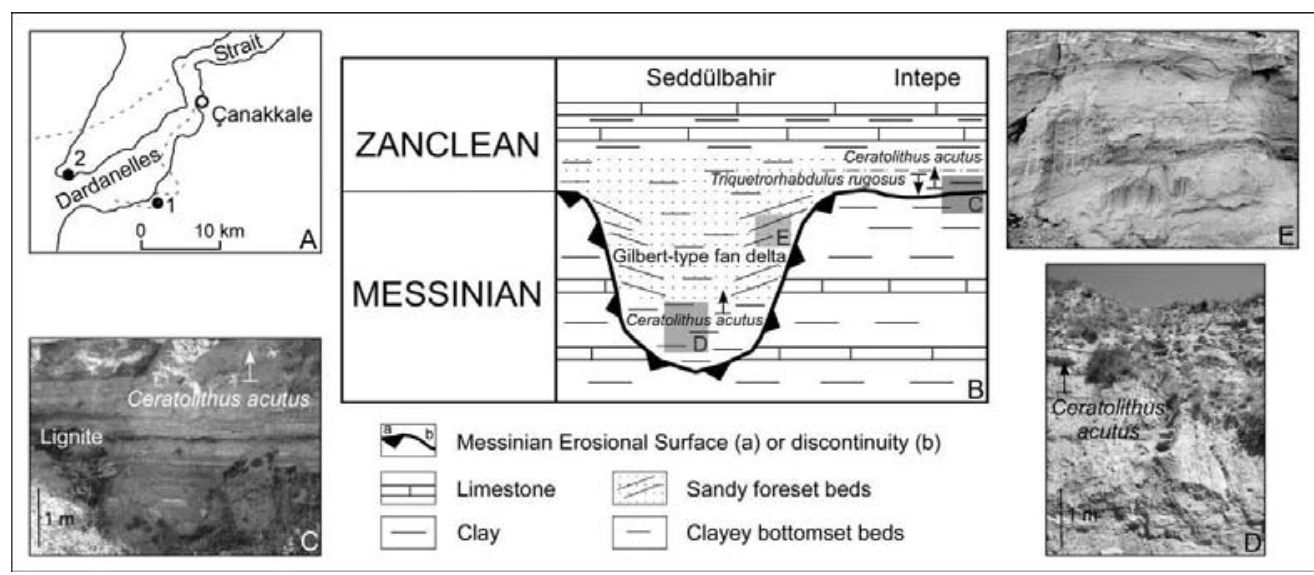

Two types of Messinian - Zanclean deposit organization in the area of the Dardanelles Strait. A, Location map. 1, Intepe; 2, Seddülbahir. The dotted grey line displays the local coastline at the end of reflooding of the Mediterranean after the MSC.

B, Intepe, a bay-lagoon locality, and Seddülbahir where a Gilbert-type fan delta infils a ria resulting from a Messinian fluvial canyon, with location of photographs $C$ to $E$.

C, Middle part of the Intepe section showing the lignite overlain by rubefied (fired) clays. D, Seddülbahir: clayey bottomset beds of the Gilbert-type fan delta. E, Sandy foreset beds of the Gilbert-type fan delta northward Intepe. 

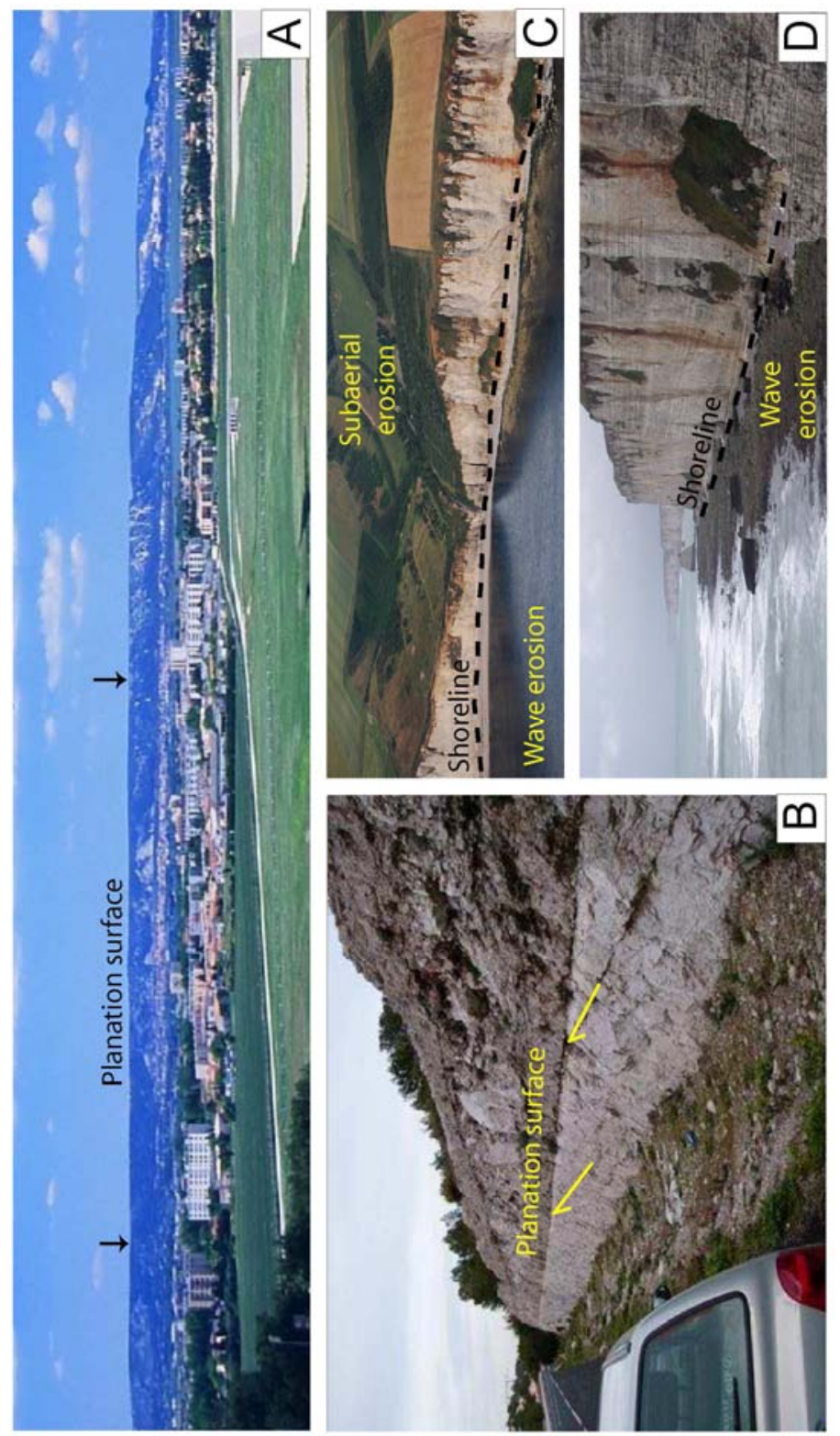

A, B, Examples of transgressive surfaces in southeastern France. These erosional surfaces, related to Miocene transgressions (Champion et al., 2000), present a smooth morphology over large distance, which may be compared with the planation surface " $e$ " highlighted in this study. On picture $B$, Cretaceous limestone deposits are truncated and overlain by Miocene transgressive deposits. Nerthe Massif, Provence. Photograph: Jean-Loup Rubino.

C, D, Examples of present shore in the North of France where the combined effect of waves and tides leads to erosion of the cliff. These shorelines are representative analogues of our interpretation of the landscape in the Gulf of Lions just before the Step II of reflooding. C, Vattetotsur-Mer, Seine Maritime. Photograph: Charlélie Coutinho. D, Etretat, Seine-Maritime. Photograph: Anne Duperret. 
Two present-day topographic profiles (A-B, C-D) illustrating the physiography of the Mediterranean Basin and some peripherial areas just after the Messinian Salinity Crisis. Sills and nearby mountains are indicated. On the profiles, vertical dotted lines indicate direction changes. The map was created using GeoMapApp System developed by Haxby et al., 2010). $166 \times 149 \mathrm{~mm}(150 \times 150 \mathrm{DPI})$ 


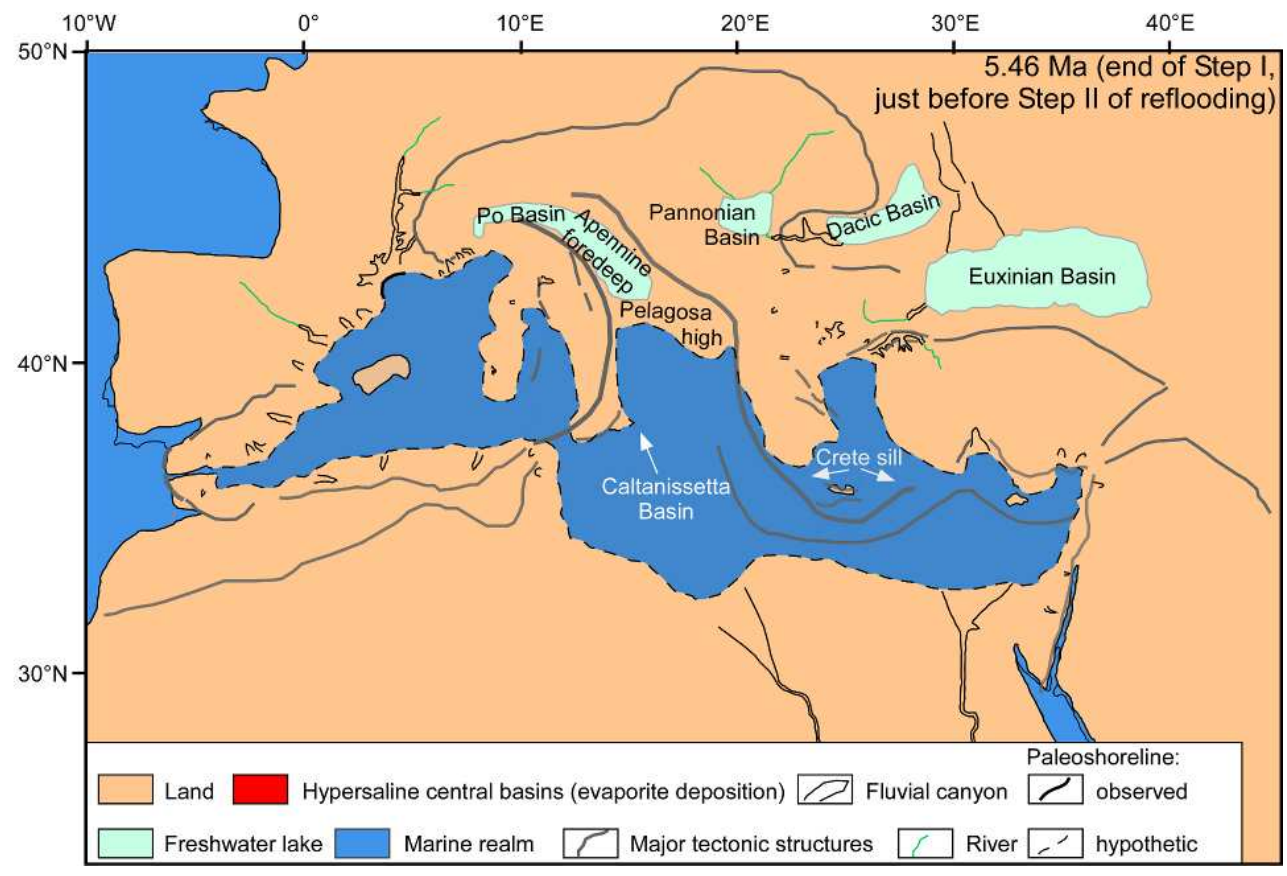

Paleogeographic map of the Mediterranean Basin and Eastern Paratethys at the end of Step I of the Mediterranean reflooding, i.e. just before the dramatic rise in sea level at 5.46 $\mathrm{Ma}$. At that time, the water level in the Mediterranean Basin was some $650 \mathrm{~m}$ below the Atlantic Ocean, the waters of which flowed into the Mediterranean. $166 \times 114 \mathrm{~mm}(150 \times 150 \mathrm{DPI})$ 


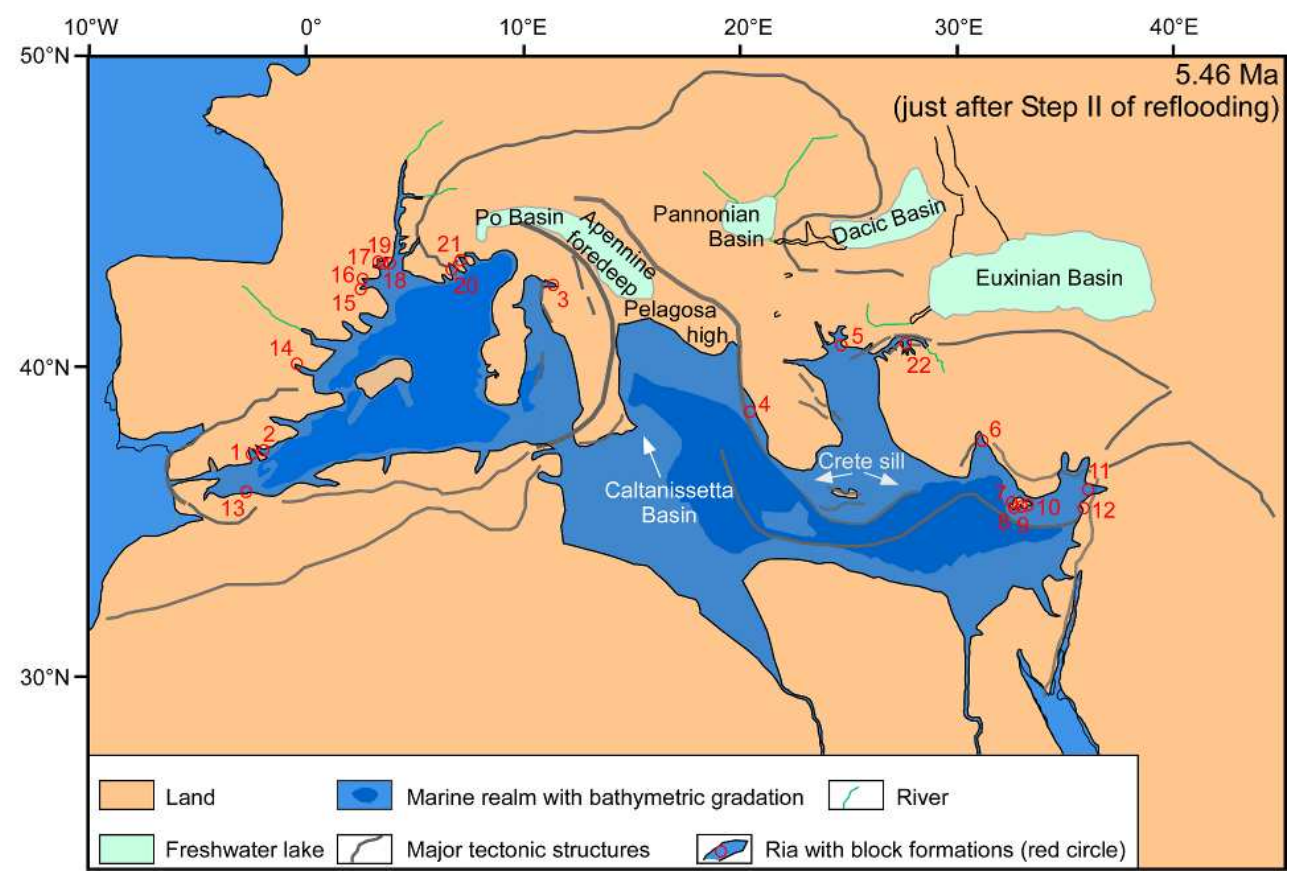

Paleogeographic map of the Mediterranean Basin and Eastern Paratethys just after Step II of the Mediterranean reflooding, i.e. just after the dramatic rise in sea level at 5.46 Ma. At that time, the Mediterranean and the Atlantic were connected (i.e. at the same sea level). The Block Formations, now frequently identified (according to literature or our own observations) at the base of the Zanclean marine sediments, are indicated by red circles.

Localities with gypsum or anhydrite blocks: Los Feos (1) in the Nijar Basin and Garrucha (2) in the Vera Basin (Clauzon, 1980b) (SE Spain); San Ippolito (3) near Volterra (Central Italy), Kalamaki (4) on the island of Zakynthos; Loutra Eleftheron (5) near Kavala (NE Greece); Gebiz (6) near Antalya (S Turkey) (Glover and Robertson, 1998); Amargeti (7), Pissouri (8) Psematismenos (9) and Boghaz (10) on the island of Cyprus; Mağaracik (11) near Samandağ (SE Turkey); Kferyeho (12) near Lattaquié (Syria).

Localities with various rocks: Oued Haddouba and Ikamba (13) in the Melilla area (N Morocco) (Cornée et al., 2006); La Pedrera (14) near San Miguel de Salinas (E Spain) (García-García et al., 2011); Le Boulou (15) and Ille sur Têt (16) near Perpignan (S France); Cessenon (17) and Magalas (18) near Béziers (Ambert et al., 1998) and Tour de Piquet and Bruque-Cabal (19) near Montpellier (Ambert, 2011) (SE France); Carros (20) in the Nice area (SE France) (Clauzon, 1978); Ventimiglia (21) (NW Italy) (Breda et al., 2007); Salzidere (22) in the Bandirma region (S Marmara Sea, N Turkey). 


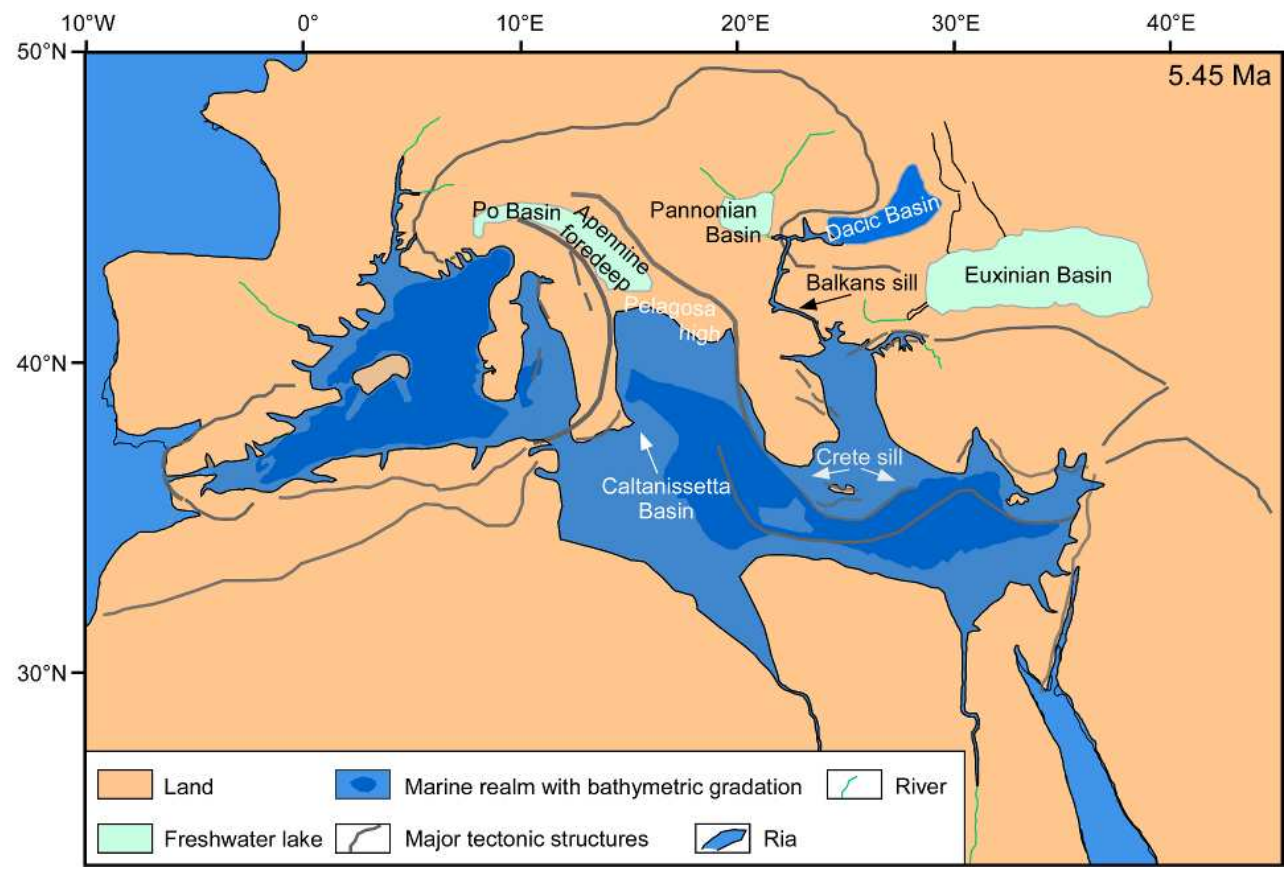

Paleogeographic map of the Mediterranean Basin and Eastern Paratethys at 5.45 Ma (after the second step of the Mediterranean reflooding) when the Mediterranean Sea and Dacic Basin reconnected due to continuing rise of global sea level. $166 \times 114 \mathrm{~mm}(150 \times 150 \mathrm{DPI})$ 

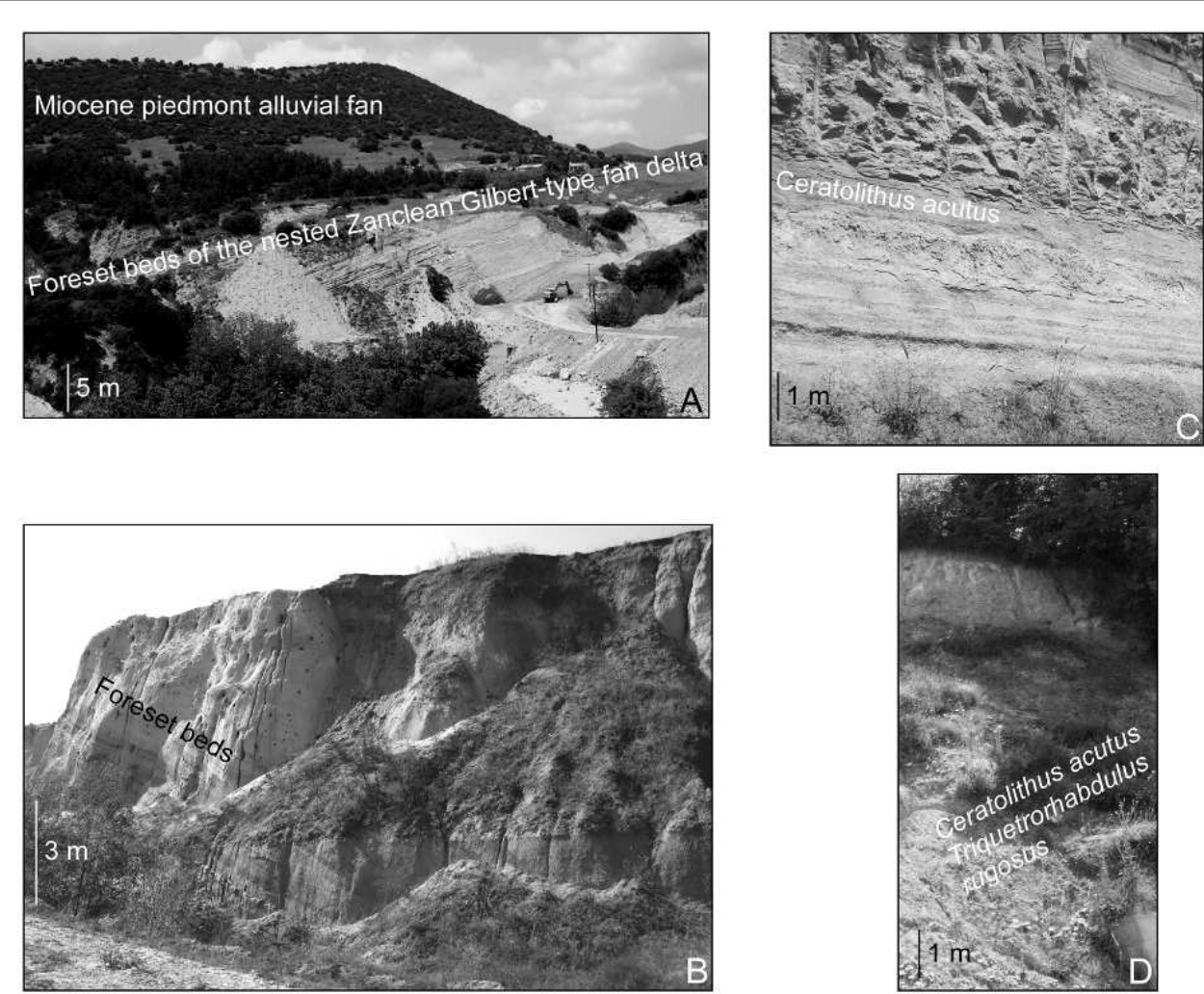

Zanclean Gilbert-type fan deltas in the Balkans.

A, Serres (Ano Metochi): foreset beds of the Zanclean Gilbert-type fan delta nested within the Miocene piedmont alluvial fan; B \& C, Zanclean Gilbert-type fan delta near Skopje: B, foreset beds at Dračevo; C, bottomset beds at Batinci; D, Niš: bottomset beds of the Zanclean Gilbert-type fan delta at Gabrovačka Reka.

$166 \times 136 \mathrm{~mm}(150 \times 150 \mathrm{DPI})$ 


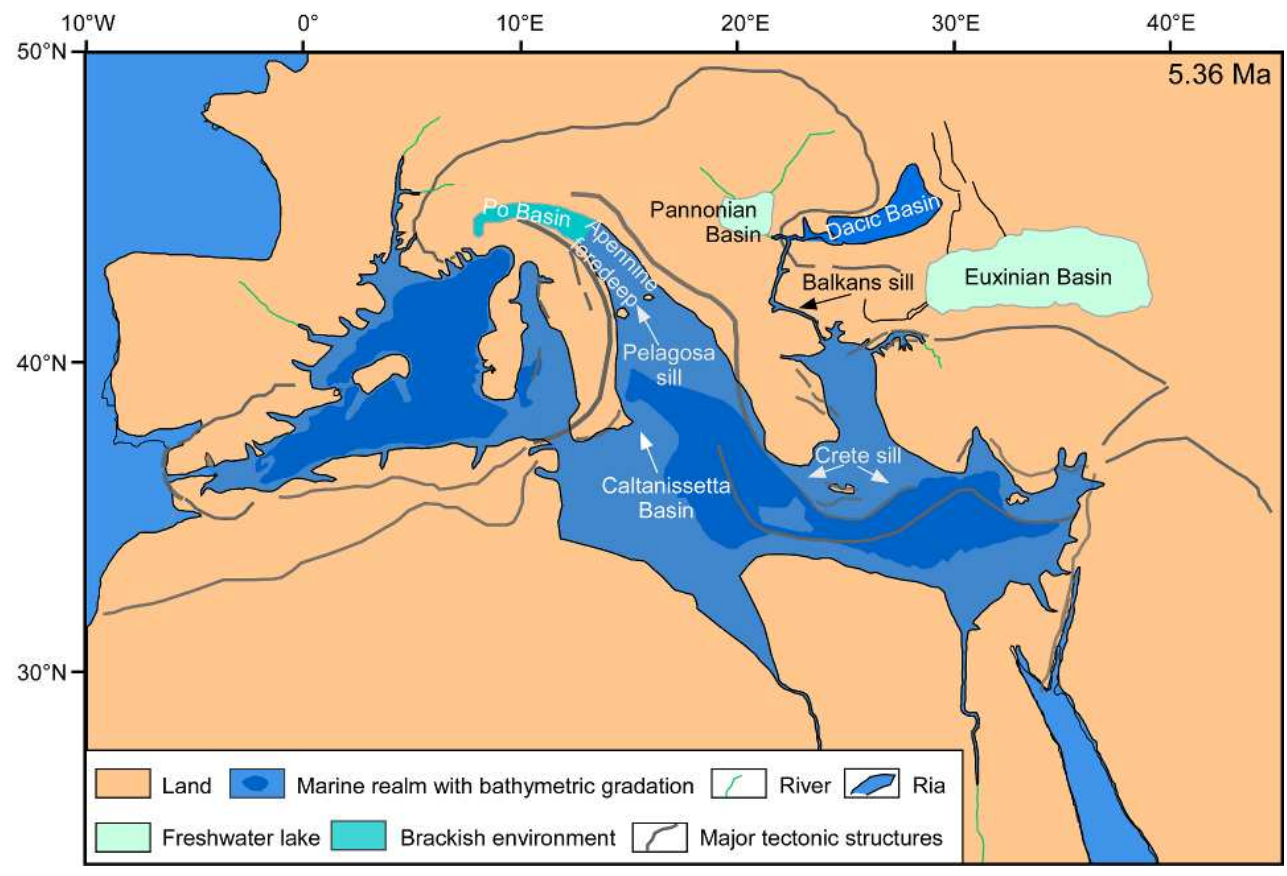

Paleogeographic map of the Mediterranean basin and Eastern Paratethys at 5.36 Ma when the Mediterranean Sea and Apennine foredeep reconnected due to continuing rise of global sea level. $166 \times 114 \mathrm{~mm}(150 \times 150 \mathrm{DPI})$ 


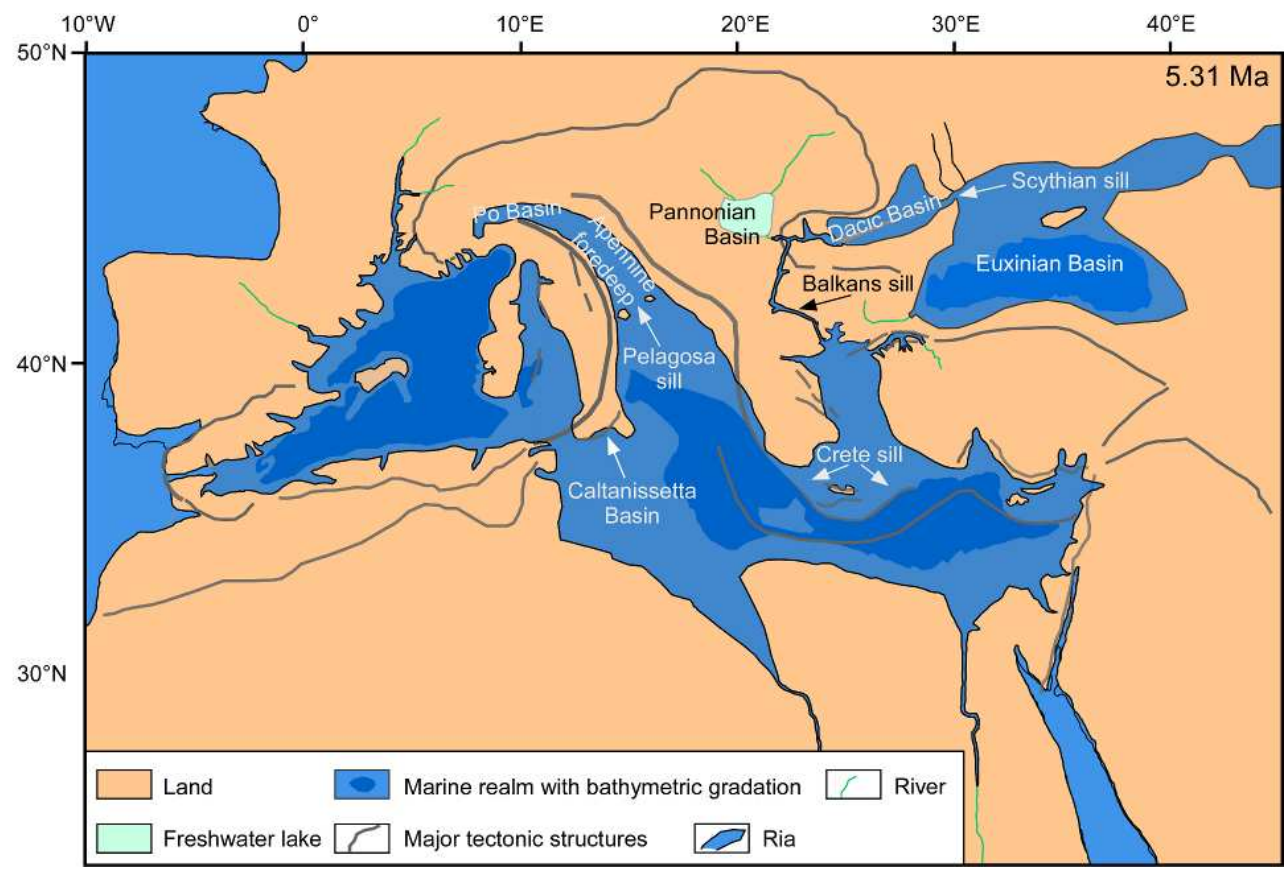

Paleogeographic map of the Mediterranean basin and Eastern Paratethys at 5.31 Ma when the Dacic and Euxinian basins connected (Popescu et al., 2010) due to continuing rise of global sea level. $166 \times 114 \mathrm{~mm}(150 \times 150 \mathrm{DPI})$ 
Estimate of the initial position of the paleoshoreline and of the planation surface " $e$ " at the beginning of the Pliocene. The Pliocene and Quaternary total subsidence is deduced from Rabineau et al. (2006).

$164 \times 116 \mathrm{~mm}(300 \times 300 \mathrm{DPI})$ 
Variation of the Mediterranean sea level in the Gulf of Lions between 6 and 5.30 Ma encompassing the Messinian Salinity Crisis, with special attention to the reflooding phase.

Successive major changes are estimated with respect to present-day sea level (noted "0"). A twostep process is highlighted:

- the First Step (? - $5.46 \mathrm{Ma}$ ) is characterized by a relative sea-level rise ( $500 \mathrm{~m}$ at the most). A first transgression flattened previous topography to build a remarkable ravinement surface (slope value between 0 and $1 \%$ );

- the Second Step (at 5.46 Ma) corresponds to an ultra-rapid Mediterranean sea-level rise contained between 600 and $900 \mathrm{~m}$ in amplitude. Just after this outstanding and sudden rise in sea-level,

Arenazzolo deposition began. After Gilbert-type fan delta sediments began to infill the rias, successive connections of the Mediterranean Basin with adjacent basins formed as global sea level continued to rise: with the Dacic Basin (Eastern Paratethys) at $5.45 \mathrm{Ma}$, with the Apennine foredeep at 5.36 Ma, at last with the Euxinian Basin (Eastern Paratethys) at 5.31 Ma (see Figures 17 to 20). 


\section{Supplementary}

Supplementary Fig. 1. Uninterpreted seismic profiles of Figure 5.

Supplementary Fig. 2. Uninterpreted seismic profiles of Figure 7.

Supplementary Fig. 3. Uninterpreted seismic profiles of Figure 8. 


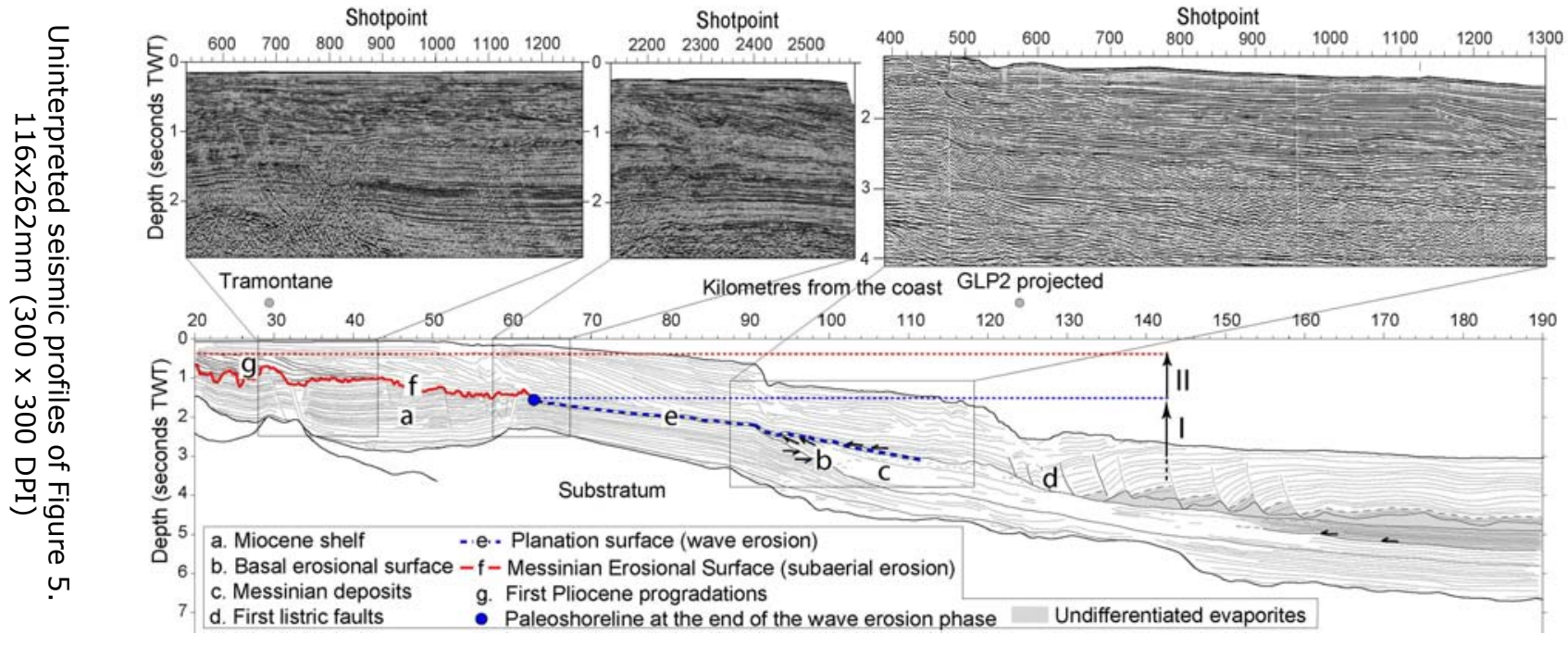



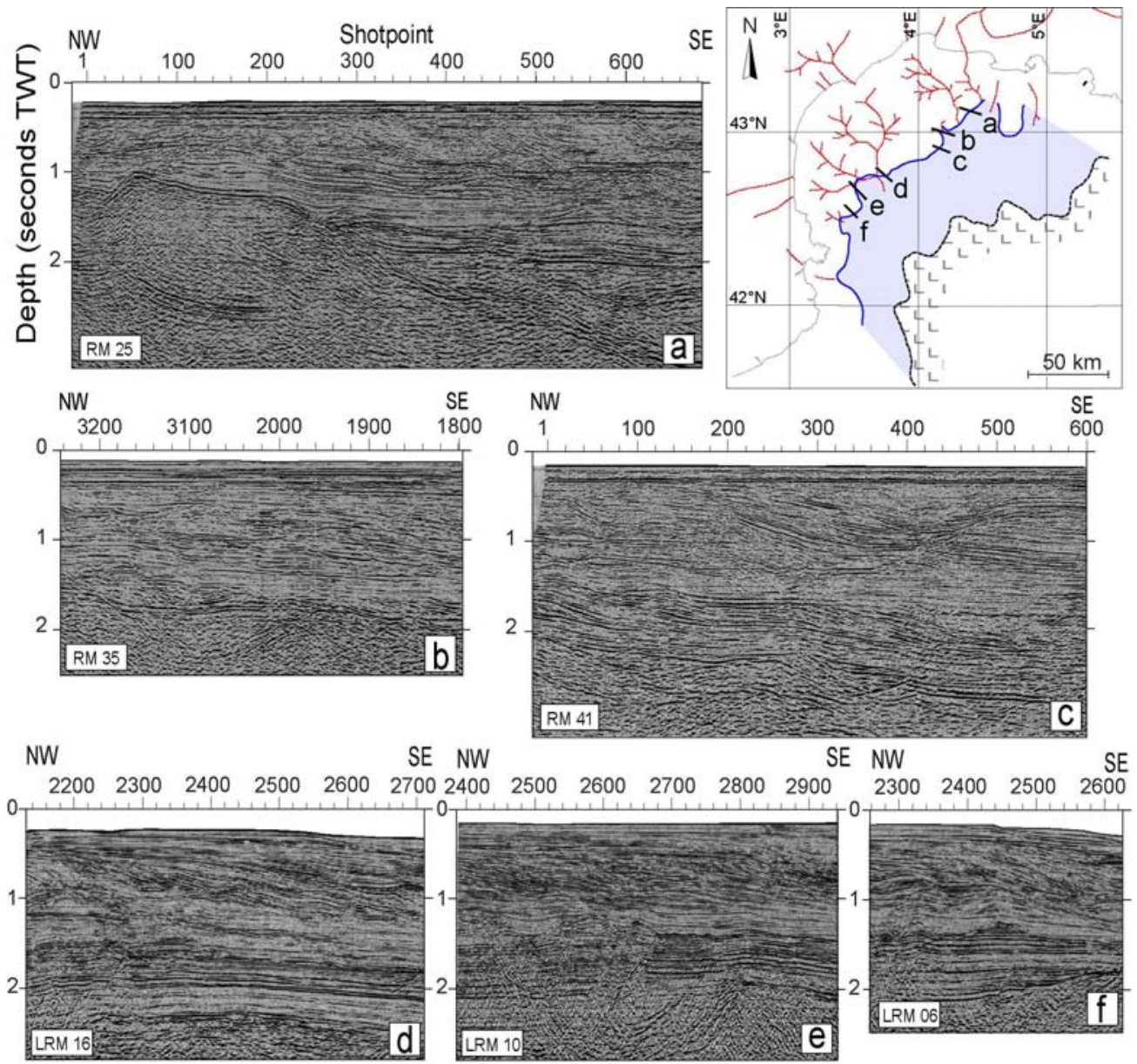

Uninterpreted seismic profiles of Figure 7 $167 \times 158 \mathrm{~mm}(300 \times 300$ DPI) 


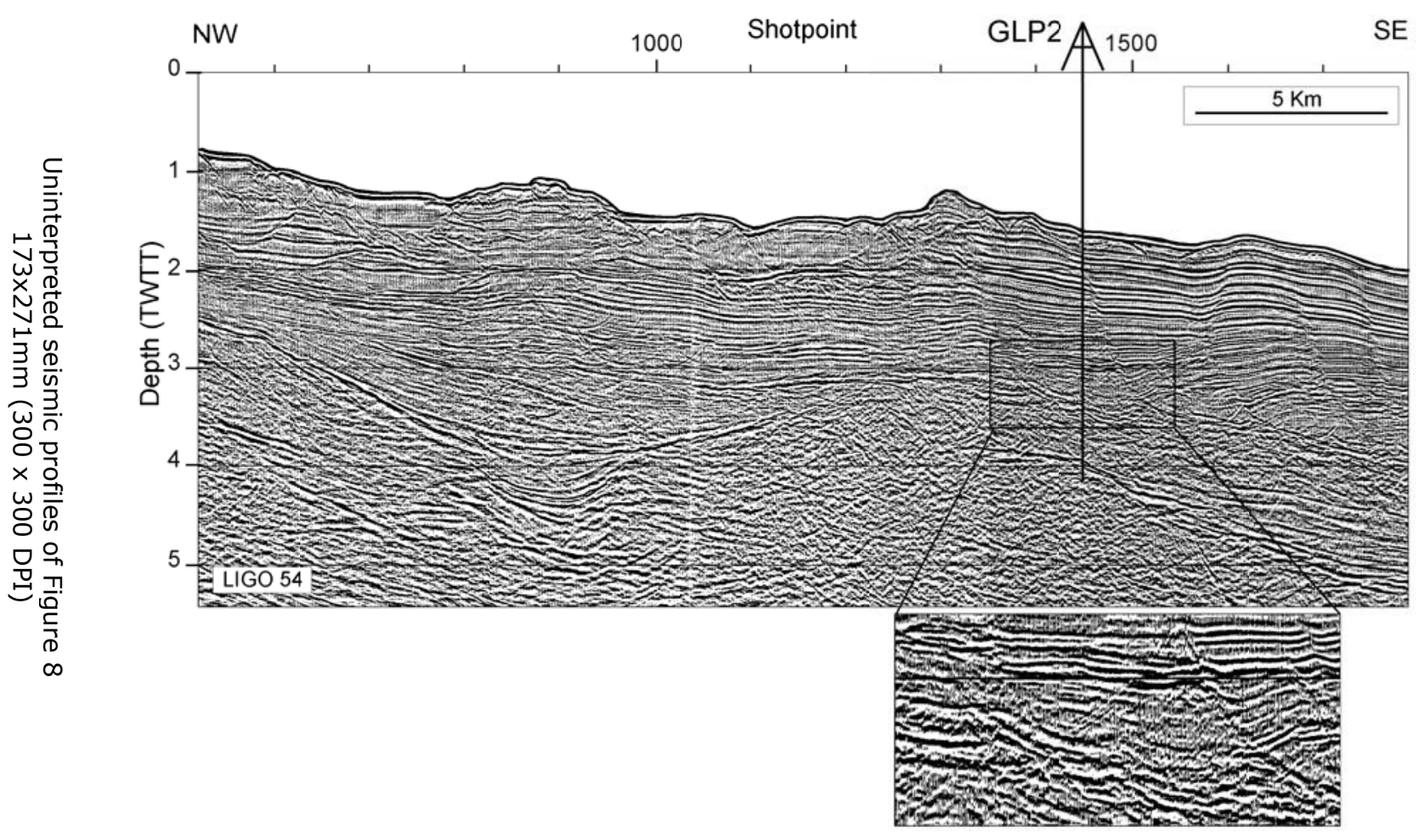

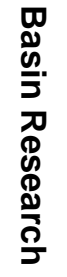

